$$
\begin{array}{r}
\text { Pontifícia Universidade C Católica } \\
\text { do Rio de Janeiro }
\end{array}
$$

Débora Cristina Bahia Fortes

\title{
Reflexões sobre alta social e intersetorialidade: experiências e desafios para os assistentes sociais do Hospital Municipal Miguel Couto/RJ
}

\section{Dissertação de Mestrado}

Dissertação apresentada ao Programa de PósGraduação em Serviço Social da PUC-Rio como requisito parcial para obtenção de grau de mestre em Serviço Social.

Orientador: Prof ${ }^{a}$ Sindely Chahim de Avellar Alchorne

Rio de Janeiro

Março de 2019 


$$
\text { Pontifícia } U_{\text {niversidade }} \text { Católica }_{\text {do Rio de Janeiro }}
$$

\title{
Debora Cristina Bahia Fortes
}

\section{Reflexões sobre alta social e intersetorialidade: experiências e desafios para os assistentes sociais do Hospital Municipal Miguel Couto/RJ}

\begin{abstract}
Dissertação apresentada como requisito parcial para obtenção do título de Mestre pelo Programa de PósGraduação em Serviço Social da PUC-Rio. Aprovada pela Comissão Examinadora abaixo.
\end{abstract}

Prof ${ }^{a}$ Sindely Chahim de Avellar Alchorne Orientador

Departamento de Serviço Social - PUC-Rio

Prof ${ }^{a}$ Mônica de Castro Maia Senna

UFF

Profo Marcelo Luciano Vieira Departamento de Serviço Social - PUC-Rio

Prof ${ }^{a}$ Ariane Rego de Paiva Departamento de Serviço Social - PUC-Rio 
Todos os direitos reservados. É proibida a reprodução total ou parcial do trabalho sem autorização da universidade, do autor e do orientador.

\section{Débora Cristina Bahia Fortes}

Graduou-se em Serviço Social, pela Universidade Federal Fluminense de Niterói-RJ (UFF), em 2013; Especializou-se em Assistência Social e Direitos Humanos, pela PUC/Rio, em 2016. Tem experiência como assistente social do Hospital Municipal Albert Schweitzer.

Fortes, Débora Cristina Bahia

Reflexões sobre alta social e intersetorialidade: experiências e desafios para os assistentes sociais do Hospital Municipal MiguelCouto/RJ / Débora Cristina Bahia Fortes; orientadora: Sindely Chahim de Avellar Alchorne. 2019.

101 f. : il. color. ; $30 \mathrm{~cm}$

Dissertação (mestrado)-Pontifícia Universidade Católica do Rio de Janeiro, Departamento de Serviço Social, 2019. Inclui bibliografia.

1. Serviço Social - Teses. 2. Alta social. 3. Intersetorialidade. 4. Serviço social. 5. Política de saúde. 6. Políticas públicas. I. Alchorne, Sindely Chahim de Avellar. II. Pontifícia Universidade Católica do Rio de Janeiro. Departamento de Serviço Social. III. Título. 


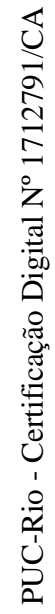

À minha família, pelo apoio sem limites. 


\section{Agradecimentos}

A Deus por seu cuidado e amor visíveis para comigo.

Aos meus pais, Luiz e Cristina, e à minha irmã, Anna Rebeca, por não medirem esforços para que eu pudesse me dedicar.

Ao meu noivo, Rodrigo, pelo amor e força nesse tempo. Às minhas avós, Anna e Hilda, que adorariam me veraqui.

A minha orientadora Professora Doutora Sindely Chahim de Avellar Alchorne, que se empenhou dia e noite, finais de semanas e férias para que eu pudesse realizar esse sonho.

Aos queridos professores da minha banca de qualificação e defesa, Professora Doutora Mônica Senna, Professora Doutora Ariane Paiva e Professor Doutor Marcelo Luciano Vieira, por todas as contribuições para esta pesquisa e pela disponibilidade.

À Coordenação de Aperfeiçoamento de Pessoal de Nível Superior (CAPES) pelo investimento nesta pesquisa.

A equipe do Hospital Municipal Miguel Couto, em especial, à assistente social Sandra Barreto, por terem aberto as portas para esse estudo.

Aos meus colegas de turma pela força nessa caminhada.

Aos demais amigos e familiares, que compreenderam minha ausência quando minha prioridade era escrever. 


\section{Resumo}

Fortes, Débora Cristina Bahia; Alchorne, Sindely Chahim de Avellar. Reflexões sobre alta social e intersetorialidade: experiências e desafios para os assistentes sociais do Hospital Municipal Miguel Couto/RJ. Rio de Janeiro, 2019, 101p. Dissertação de Mestrado - Departamento de Serviço Social, Pontifícia Universidade Católica do Rio de Janeiro.

Esta pesquisa discute a alta hospitalar em casos que necessitam de atuação do Serviço Social, ou seja, aquela que se convencionou chamar de "alta social", pois implica na permanência do paciente em unidade hospitalar mesmo após alta médica. Essa percepção, busca olhar o sujeito em sua integralidade, para além do biológico. Os objetivos da pesquisa circunscrevem-se em: pesquisar os principais fatores que podem determinar entraves para "alta social"; entender quando o assistente social é requisitado para participar do processo de alta; compreender em quais casos os assistentes sociais buscam acionar a rede de apoio e se, nos casos apresentados, houve contribuição para a "alta social" a partir da intersetorialidade; apreender como a intersetorialidade se configura como caminho possível para atuação da equipe multiprofissional na intervenção da "alta social".Essa pesquisa teve como campo empírico o Hospital Municipal Miguel Couto, localizado no município do Rio de Janeiro. Por meio de dados obtidos nas fichas sociais, instrumento de trabalho dos assistentes sociais na Saúde, analisamos as redes de apoio buscadas por esses profissionais para atuarem junto às questões de alta, no intuito de entender como a intersetorialidade aparece de forma transversal durante intervenções em "alta social", o que ainda é um obstáculo a ser enfrentado. Assim, o conceito de intersetorialidade adotado por essa pesquisa se apresenta como sendo, muito mais do que juntar setores, é criar uma nova dinâmica para o aparato governamental, com base territorial e populacional. Na concepção ampliada de Saúde, a intersetorialidade surge como proposta de uma nova forma de trabalhar, de governar e de construir políticas públicas. Dessa forma, a pesquisa mostrounos desafios e conquistas da equipe de Serviço Social do Hospital supracitado.

\section{Palavras-chave}

Alta Social; Intersetorialidade; Serviço Social; Política de Saúde; Políticas Públicas. 


\section{Abstract}

Fortes, Débora Cristina Bahia; Alchorne, Sindely Chahim of Avellar (Advisor). Reflections on social discharge and intersectoriality: experiences and challenges for the social workers of the Municipal Hospital Miguel Couto/RJ. Rio de Janeiro, 2019, 101p. Dissertação de Mestrado - Departamento de Serviço Social, Pontifícia Universidade Católica do Rio de Janeiro.

This research discusses hospital discharge in cases requiring Social Service work, that is, the one that is known as "social discharge", since it implies that the patient stays in a hospital unit even after discharge from the hospital. This perception seeks to look at the subject in its entirety, beyond the biological. The objectives of the research are circumscribed in: research the main factors that can determine obstacles to "social discharge"; understand when the social worker is asked to participate in the discharge process; to understand in which cases the social workers seek to activate the support network and if, in the cases presented, there was contribution to the "social discharge" from the intersectoriality; to apprehend how the intersectoriality is configured as a possible way for the multiprofessional team to act in the intervention of the "social discharge." This research had as an empirical field the Municipal Hospital Miguel Couto, located in the city of Rio de Janeiro. Through data obtained in the documents, a tool of work of social workers in Health, we analyze the support networks sought by these professionals to work with the discharge issues, in order to understand how intersectoriality appears transversally during interventions in "social discharge", which is still an obstacle to be faced. Thus, the concept of intersectoriality adopted by this research presents itself, being, therefore, much more than joining sectors, is to create a new dynamic for the governmental apparatus, based on territorial and population. In the expanded conception of Health, intersectoriality appears as a proposal for a new way of working, governing and building public policies. Thus, the research showed us the challenges and achievements of the Social Work team of the abovementioned Hospital.

\section{Keywords}

Social discharge; Intersectoriality; Social service; Health Policy; Public policy. 


\section{Sumário}

1. Introdução

2. Cidadania no Brasil, política de Saúde eServiço Social 19

2.1. Construção da cidadaniano Brasil 19

2.2 A Política de Saúde como direito de Cidadania no Brasil e a 28 luta do Serviço Social por essa conquista

3. Estratégias para prática dos assistentes sociais na políticade $\quad 40$ Saúde

3.1. O Serviço Social na Saúde: inserção e prática profissional $\quad 40$

3.2. Notas sobre intersetorialidade: alternativas paraa prática 48 profissional dos assistentes sociais

4. "Alta Social": dilemas, desafios e possibilidades - a realidade da emergência do Hospital Municipal Miguel Couto

4.1. Trajetória acadêmica e pesquisade campo

4.2. "Alta Social" e Serviço Social: há possibilidade a partir da intersetorialidade?

4.3. "Alta Social" e Serviço Social no HMMC

5. Considerações finais

6. Referências bibliográficas

7. Anexos

8. Apêndices 


\section{Lista de figuras}

Figura1- Obstáculos para saída do paciente dealta hospitalar 17

Figura 2- Pirâmide cronológica da cidadania naGrã-Bretanha 23

Figura 3- Modelo de DSS adotado pelo CNDSS-Brasil 33

Figura 4- Portugal Notícia: Pessoas com alta médica permanecem $\quad 80$ no hospital

Figura 5- Paraná online - Notícia: Mesmo com alta pacientes 80 permanecem internados

Figura 6- Demandas historicamente dirigidasaosassistentes

81 sociais que trabalham em unidades de saúde 


\section{Lista de gráficos e tabelas}

Tabela 1- Quantitativo de fichas sociaisanalisadasnesta pesquisa

63

Gráfico 1- Caracterização dos usuários atendidos pelo Serviço

64

Social do HMMC entre 2016 e 2017 - Quanto à nacionalidade

Gráfico 2- Perfil dos usuários atendidos peloServiço Social do

65

HMMC entre 2016 e 2017 - Quanto ao sexo

Gráfico 3- Perfil dos usuários atendidos peloServiço Social do HMMC entre 2016 e 2017 - Quanto à idade

66

Gráfico 4- Perfil dos usuários atendidos peloServiço Social do

67

HMMC entre 2016 e 2017 - Quanto à posse de documento deidentificação

Gráfico 5- Estimativa do sub-registrodenascimentos

68

Gráfico 6- Intersetorialidade no HMMC entre 2016 e 2017 -

72

casos de "alta social"

Gráfico 7- Interdisciplinaridade entreassistentes sociais e demais equipes do HMMC

75

Gráfico 8- Principais demandas de criançaseadolescentes

82

atendidos pelo Serviço Social

Gráfico 9- Principaisdemandas dos adultos (18 a59 anos)

83

atendidos pelo Serviço Social

Gráfico 10- Principaisdemandas de idosos atendidospelo

85 Serviço Social 


\section{Lista de siglas}

$\begin{array}{ll}\text { AP } & \text { Área Programática } \\ \text { CAP } & \text { Caixas de aposentadorias e pensões } \\ \text { CEAS } & \text { Centro de Estudos e ação social de São Paulo } \\ \text { CER } & \text { Coordenação de Emergência Regional }\end{array}$

CNDSS Comissão Nacional sobre Determinantes Sociais de Saúde

CRAS Centro de Referência de Assistência Social

CREAS Centro de Referência Especializado de Assistência Social

CRESS Conselho Regional de Serviço Social

DETRAN Departamento de Trânsito do Estado do Rio de Janeiro

DDPA Delegacia de Descoberta de Paradeiros

DSS Determinantes Sociais de Saúde

FGTS Fundo de Garantia do Tempo de Serviço

FIOCRUZ Fundação Oswaldo Cruz

HMMC Hospital Municipal Miguel Couto

HMAS Hospital Municipal Albert Schweitzer

HMTJ Hospital Municipal Terezinha de Jesus

IAPS Instituto de aposentadorias e pensões

LOS Lei Orgânica de Saúde

MDB Movimento Democrático Brasileiro

NASF Núcleo de Apoio à Saúde da Família

PADI Programa de Atenção Domiciliar ao Idoso

PMDB Partido do Movimento Democrático Brasileiro

PT Partido dos Trabalhadores 

OMS Organização Mundial de Saúde
OSS OrganizaçãoSocial de Saúde
SUS Sistema Único deSaúde
UPA Unidade de ProntoAtendimento 


\section{1 \\ Introdução}

Este estudo tem como objetivo analisar a "alta social" como um campo da prática profissional de Assistentes Sociais, nesse caso, em uma Unidade de Saúde de alta complexidade localizada no bairro do Leblon, no município do Rio de Janeiro - Hospital Municipal MiguelCouto.

Para chegarmos ao objetivo proposto aqui, compreendemos que foi preciso desvendar os seguintes objetivos específicos:

- $\quad$ Pesquisar os principais fatores que podem determinar entraves para "altasocial";

- $\quad$ Entender quando o assistente social é requisitado para participar do processo dealta;

- $\quad$ Compreender em quais casos os assistentes sociais buscam acionar a rede de apoio e se, nos casos apresentados, houve contribuição para a "alta social";

- $\quad$ Entender se a intersetorialidade se configura como caminho possível para atuação da equipe multiprofissional na intervenção da "altasocial".

Para iniciarmos nossa discussão, gostaríamos de deixar expresso que, quando utilizamos o termo "alta social", não estamos querendo uma separação no processo de alta. Pelo contrário, entendemos que a alta é uma demanda complexa no que tange à hospitalização de um sujeito e (que) não pode ser vista de maneira segregada. A alta deveria envolver todos os setores, as redes familiar e comunitária e todos os profissionais para que se dê de forma mais pertinente possível, especialmente para pacientes e familiares.

Apesar disso, compreendemos que o termo "alta social" vem sendo aplicado nos espaços institucionais como forma de indicar que a alta foi dada pela equipe médica, mas outros determinantes sociais impedem que a alta aconteça de maneira adequada para a saúde de pacientes e, consequentemente, de seus familiares.

Por isso, estaremos fazendo menção à "alta social" sempre entre aspas, indicando que, compreendemos e lutamos para que a alta ocorra de forma integral, tanto no que tange ao olhar profissional quanto aos cuidados do processo saúde- doença como cuidados para além das unidades de saúde. Entretanto, não podemos negar a banalização do termo instalada nas instituições e que deve ser combatida. 
Esse trabalho foi orientado pelo conceito de pesquisa qualitativa, de acordo coma perspectiva de Minayo (2010), a qual afirma que esse tipo de abordagem se aprofunda no mundo dos significados das ações e das relações humanas, um lado não perceptível e não captável em equações, médias e estatísticas.

Logicamente, não descartamos a utilização de dados quantitativos, não como forma de apresentar a realidade social, mas como linguagem que expressa objetivamente a amostra do nosso estudo. Afinal, não são informações que se opõem, mas se complementam.

Para essa investigação, realizamos um levantamento bibliográfico de autores que discutem a política de saúde e, mais especificamente, o processo da "alta social". Analisarmos teoricamente a temática irá contribuir na elaboração de nossas referências para seguir um caminho para construção do conceito da intersetorialidade, tão debatida entre os pesquisadores na atualidade.

Inicialmente havíamos considerado ser viável adotarmos as bases epistemológicas do conceito de Regime de Informação, de acordo com o modelo proposto por Gonzalez de Gomez, utilizado por Vieira (2015), que trata de mapear atores, dispositivos, artefatos e ações deinformação.

Segundo Frohmann (1995, p. 4 apud Delaia e Freire, 2010, p. 109), o conceito de Regime de Informação consiste em um conjunto de redes no qual as informações são transferidas de seus produtores, por canais determinados, com a mediação de estruturas organizacionais às comunidades específicas ou aos consumidores. Assim, as informações podem ser geradas, organizadas e transferidas de diferentes produtores, através de muitos e diversos meios, canais e organizações, a diferentes destinatários ou receptores através de diferentes meios decomunicações.O Regime de Informação é um método de abordagem que procura mapear todos os dispositivos (documentais) da instituição a fim de que seja possível analisá-la.

Como não houve tempo hábil nesse estudo para estruturar todos os artefatos, optamos por utilizar um instrumento de trabalho de assistentes sociais, que é o profissional de interesse nessa pesquisa, aplicando, pois, a metodologia análise documental que será melhor descrita mais adiante.

O material utilizado nessa análise foram as fichas sociais, que são recursos de trabalho utilizados por assistentes sociais. Elas consistem em ser um documento de posse do referido profissional e são abertas durante os atendimentos, junto aos usuários e/ou familiares. Na primeira página, consta um papel timbrado com lacunas para preenchimentos de dados básicos, como nome 
completo, endereço, telefone, pessoas com quem o paciente reside, renda familiar, entre outros. A partir daí são descritas outras informações livres e de maneira discursiva que apontem, além do relato do caso, todos os procedimentos adotados pelos assistentes sociais atuantes no caso desde a entrada até a alta ou saída do paciente.

Buscamos trabalhar com materiais próprios do Serviço Social, priorizando o sigilo profissional, conforme o Código de Ética, mas vislumbrando o acesso à informação, por meio de documentos de caráter público. Esses documentos abarcam um período de 02 (dois) anos, 2016 e 2017, vale ressaltar, somente aqueles que foram utilizados em casos que envolveram a participação do Serviço Social nos processos de altahospitalar.

Por se tratar de análise dos documentos de caráter e interesse públicos, não vislumbramos possíveis constrangimentos. Nosso contato com a equipe se deu de maneira que, voluntariamente, ela nos possibilitou o acesso aos materiais institucionais que tratem a respeito da "alta social" naquela unidade.

Assim, a pesquisa agrupou estudos bibliográficos, buscando a compreensão da realidade e o desvendamento do momento político do qual estamos tratando, dados no sentido de compreender qualitativamente as possibilidades e os entraves dos profissionais em atuar diante da "alta social", na perspectiva da intersetorialidade e conhecer histórias cotidianas na tentativa de compreender o cenário e propor formas de enfrentamento.

O fazer profissional também deve ser visto como campo de produção de conhecimento, afinal ele é lugar onde o método científico será aplicado. Esse movimento é importante para que não haja um distanciamento entre teoria e prática.

Nesse tópico, gostaríamos de abordar um pouco sobre o caminho que tracei para realização dessa pesquisa, desde que entrei para o mestrado da PUC-Rio até o momento da pesquisa de campo. Para isso, preciso voltar em 2014, quando fui contratada para meu primeiro emprego como assistente social. Aquela seria minha segunda experiência profissional dentro de uma unidade hospitalar de atenção terciária. A primeira havia sido quando ainda era acadêmica de Serviço Social em que, em 2010, fui estagiária do Hospital Geral de Nova Iguaçu, baixada fluminense. Em todos esses momentos, lidei com a alta hospitalar e sempre levantei muitosquestionamentos.

Em 2016, ingressei para fazer minha primeira especialização em Assistência Social e Direitos Humanos na PUC/Rio, pólo Duque de Caxias, baixada fluminense. Apesar de essa pós-graduação ser voltada para o campo da 
Assistência Social, no trabalho de conclusão do curso, optei por trazer minha vivência e estudos na área da Saúde, o que culminou em um artigo, orientado pelo professor Marcelo Luciano Vieira, hoje publicado em livro, sob coordenação da Professora Sindely Alchorne, em que realizamos um comparativo entre aspolíticas de Assistência Social (SUAS) e a política de Saúde (SUS) gerando resultados interessantes ${ }^{1}$.

Em 2017, fui aprovada na seleção do mestrado da PUC-Rio², pólo Gávea, em que eu propunha pesquisar, inicialmente, sobre intersetorialidade, ainda que, naquele momento, estivesse "bastante crua" sobre a temática.Ao longo das aulas do mestrado pude compreender melhor o conceito de intersetorialidade e me aproximar da discussão que envolve a prática profissional. Assim, por conta de minhas reflexões, estudos envolvendo essas temáticas, orientações e propostas apresentadas durante a banca de qualificação, alinhei meu objeto de pesquisa àquilo como que se apresentahoje.

Essa pesquisa, entretanto, surgiu a partir das inquietações durante minha trajetória profissional, como assistente social, na área da saúde, nos anos de 2014 a 2016, no Hospital Municipal Albert Schweitzer, em Realengo. Naquele momento, essa unidade era gerida pela Organização Social de Saúde "Hospital e Maternidade Terezinha de Jesus" e estava com fomento financeiro do governo do Estado do Rio de Janeiro, até sua municipalização em 2016. O Hospital Municipal Albert Schweitzer é uma unidade de Saúde localizada na zona Oeste (periferia) do Rio de Janeiro e atende serviços de atenção terciária.

Durante meu exercício profissional no referido hospital, trabalhei com diferentes demandas como realização de palestras, de cunho políticoeducacional com pacientes e acompanhantes; elaboração de relatório e pareceres; atendimento individualizado para orientação quanto aos direitos sociais; participação junto às equipes multiprofissionais; atuação perante pacientes de alta hospitalar com impossibilidade de saída por motivos de cunho social, etc.

A última demanda requer certo esforço profissional do assistente social. Dentro do ambiente hospitalar, quando o paciente recebe "alta médica", mas possui alguma questão de ordem social que o impossibilita de deixar o hospital

\footnotetext{
1 Para ver mais sobre isso, procure por FORTES, Débora C. B. Políticas de Saúde e de Assistência Social: um comparativo como prevenção contra a janela de uma gestão privatizadora In Textos e Contextos da Política de Assistência Social no Brasil / organização Sindely Alchorne - 1 ed. - Rio de Janeiro. Letra Capital, 2017. 400 p. (Assistência Social e Direitos Humanos, 1).

2 Gostaria aqui de fazer menção ao meu ex-orientador e ex-coordenador da pós-graduação em Assistência Sociale Direitos Humanos: Márcio Brotto. Ele, infelizmente, não chegou a me orientar nesta pesquisa, pois havia falecido pouco antes de iniciarmos o semestre. Em seguida, já fui recebida como orientanda pela professora Sindely Alchorne, a quem só tenho a agradecer.
} 
por meios próprios, essa "impossibilidade" é denominada, institucionalmente, como "alta social". Dentre os motivos observados que criavam obstáculos para saída do paciente de altaestavam:

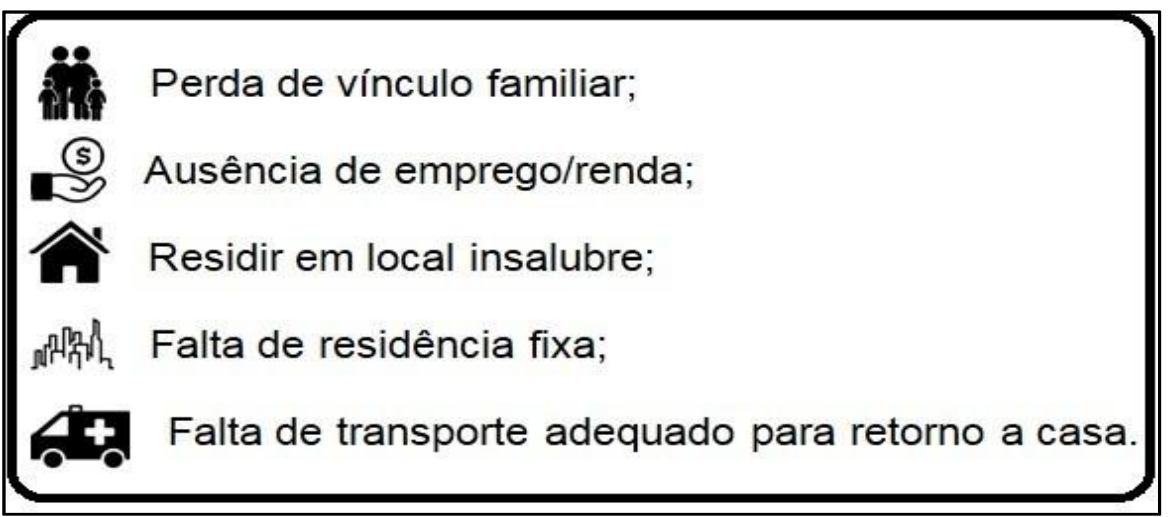

Figura 1- Obstáculos para saída do paciente de alta hospitalar.

Fonte: Formulação própria (2019).

Portanto, essa pesquisa, além de discutir sobre a "alta social, tem por objetivo também contribuir com a luta da classe trabalhadora na conquista do acesso aos direitos referentes à saúde coletiva, entendido aqui como todos os direitos que incidem no processo saúde-doença, como direito à moradia, ao emprego e renda, ao transporte público eficiente, etc.

Apesar da minha expriência ter sido no Hospital Municipal Albert Schweitezer, optei por trazer como pesquisa de campo o Hospital Municipal Miguel Couto pela proximidade com a universidade com a qual minha pesquisa está vinculada e pelo interesse dos funcionários com este estudo. Além disso, o contexto do HMAS também mudou após minha saída: a unidade foi municipalizada, houve troca de OSS (hoje a gerência está sob os cuidados da Cruz vermelha), além das mudanças em relação aos recursos humanos (mudou a direção, a coordenação do Serviço Social e os colegas de trabalho. Todos demitidos com as mudanças relatadasanteriormente).

Para pesquisa de campo, analisamos um hospital de emergência do Município do Rio de Janeiro: o Hospital Municipal Miguel Couto - localizado na Gávea, Zona Sul, fundado em 25 de outubro de1936.

Um ponto interessante que devemos observar é que a unidade citada não possui gestão privada em todos os seus setores (apenas para atuação do Programa de Atenção Domiciliar ao Idoso - PADI - e na Coordenação de Emergência Regional - CER), ou seja, a gestão de setores, como a emergência pertencem ao Município.

O HMMC, pertencente à AP área programática 2.1, ou seja está inserido 
na zona sul da cidade, que é a área nobre do Rio de Janeiro, assim como toda rede de proteção social com a qual se relaciona, que também está localizada na área mais nobre da cidade, o que pode nos revelar uma interação maior de serviços ofertadas se comparada com outras regiões da cidade do Rio de Janeiro, posto que estudos revelam que a maior parte de serviços sociais encontram-se ofertados nessa localidade.

A partir do exposto, como meio de abarcar os objetivos propostos, o presente estudo se divide em 3 capítulos, além da introdução. O segundo capítulo trata da política de saúde, enquanto direito de cidadania no Brasil e o papel do Serviço Social nessa área.Neste capítulo, traçamos um pouco da trajetória para a conquista da Cidadania, da diferença conceitual entre autores, do nosso olhar sobre a Saúde como direito e do papel do Serviço Social para essa busca pela efetividade. Foi aqui também que demos destaque ao Sistema Único de Saúde - SUS - como uma das políticas sociais de maior conquista para a sociedade brasileira.

O terceiro capítulo se debruça sobre algumas notas em torno da intersetorialidade e o Serviço Social, com enfoque na área da saúde e em especial no que tange à "alta social". Dissertamos sobre a prática profissional do assistente social e como a intersetorialidade aparece como tema correlato para as ações desseprofissional.

O quarto capítulo aborda os dilemas, desafios e possibilidades da "alta social", a partir da realidade da atuação profissional do Serviço Social do Hospital Municipal Miguel Couto. Para a construção deste capítulo, analisamos as fichas sociais de 2016 e 2017 do Hospital Municipal Miguel Couto e, a partir dele, traçamos a caracterização dos usuários atendidos pelo Serviço Social, em iminência de "alta social". Verificamos ainda em quais momentos o contato com outra política é buscado na tentativa de resolutividade dos casos e se isso pode ser chamado de intersetorialidade. Verificamos ainda quais as principais articulações entre a unidade e outros setores e em quais casos o Serviço Social tem maior prestígio entre a equipe multiprofissional e qual a importância disso na correlação deforças.

Nosso intuito é contribuir para o debate em torno de um dos grandes desafios profissionais na área da saúde: a "alta social". Temos, contudo, a clareza de não esgotar o estudo e nem tampouco de termos respostas prontas e infalíveis para a problemática ora apontada. 


\section{2 Cidadania no Brasil, política de Saúde e Serviço Social}

Neste capítulo apresentamos como se deu a conquista da Cidadania no Brasil baseada no tradicional modelo de inglês T.H. Marshall. Este autor é assumido aqui como referência por ter sido o primeiro autor a trabalhar com a cidadania no entendimento a partir de três grupos de direitos, civis, políticos e sociais. Mas, não se assume aqui, o entendimento linear de sua leitura do fenômeno na Inglaterra. De igual modo, referenciamos os estudos do Prof José Murilo de Carvalho que, assume o mesmo modelo, mas busca entender a realidade brasileira. Mostramos também como esse conceito é amplo e pode abarcar significados distintos de acordo com as teorias e/ou interesses. A seguir, apresentamos como o Serviço Social contribuiu na luta pela efetivação desse direito e como a saúde está nela inserida.

O objetivo desse capítulo foi contextualizar historicamente como se deu a trajetória da conquista do Sistema Único de Saúde do Brasil como um direito de cidadania. Mais a frente compreendermos como o processo de alta está inserido nesse contexto e deve ser garantido como um aspecto do cuidado emsaúde.

\section{1. \\ Construção da cidadania no Brasil}

Cidadania é um termo que vem sendo utilizado atualmente de forma indiscriminada no cotidiano, na mídia, nas redes sociais. Referem-se a ela quando querem tratar sobre eleição, em campanhas contra o descarte de lixo em vias públicas, educação no trânsito, entre outros.Ou como defende Benevides (2004), muitas vezes, já ouvimos, por exemplo, de uma autoridade política a expressão: "a cidadania decidirá"; "precisamos ouvir a voz da cidadania! ".

Diante disso, usa-se a palavra cidadania como sinônimo de povo, no sentido de conjunto de cidadãos, que é o sentido democrático de povo. Já no neoliberalismo, a cidadania é entendida como um conceito estritamente individualista e associado ao mercado. Mas essas acepções são insuficientes para conceituar a cidadania e abordá-la em sua complexidade. Por isso, faz-se necessário que comecemos nosso debate tratando a respeito do conceito de cidadania, com a qual vamos trabalhar.

Coutinho (1997) entende que cidadania é a capacidade conquistada por 
alguns ou todos os indivíduos de se apropriarem dos bens socialmente criados e é resultado de uma luta permanente.

Essa "apropriação" de que trata o referido autor foi conquistada ao longo da história da humanidade, inicialmente na Grécia Antiga, para que ocorresse a inserção daqueles que sesentiam excluídos da esfera pública. Mais recentemente, temos compreendido a cidadania ligada à ideia de direitos.

Entender que o conceito de cidadania, conforme estamos tratando aqui, está diretamente ligado a uma ideia eminentemente política e não aos valores universais, é importante para colocarmos a luta da classe trabalhadora no protagonismo da história brasileira.

Do contrário, estaríamos reforçando a ideia de que nossos direitos foram cedidos por governos heroicos e paternalistas, o que seria uma inverdade. A construção dos nossos direitos de cidadania foi conquistada por meio de atos políticos e não de benevolência.

Benevides (2004) busca distinguir o conceito de cidadania e de direitos humanos. Segundo a autora, direitos de cidadania não são direitos universais, são direitos específicos dos membros de um determinado Estado, de uma determinada ordem jurídico-política. No entanto, em muitos casos, os direitos do cidadão coincidem com os direitos humanos, que são os mais amplos e abrangentes.

Segundo a referida autora,

A ideia da cidadania é uma ideia eminentemente política que não está necessariamente ligada a valores universais, mas a decisões políticas. Um determinado governo, por exemplo, pode modificar radicalmente as prioridades no que diz respeito aos deveres e aos direitos do cidadão; pode modificar, por exemplo, o código penal no sentido de alterar sanções; pode modificar o código civil no sentido de equiparar direitos entre homens e mulheres, pode modificar o código de família no que diz respeito aos direitos e deveres dos cônjuges, na sociedade conjugal, em relação aos filhos, em relação um ao outro. Pode estabelecer deveres por um determinado período, por exemplo, àqueles relativos à prestação do serviço militar. Tudo isso diz respeito à cidadania. Mas, o mais importante é o dado a que me referi inicialmente: direitos de cidadania não são direitos universais, são direitos específicos dos membros de um determinado Estado, de uma determinada ordem jurídico-política (Benevides, 1998, p.4).

Por estarem sujeitos a uma determinada e específica ordem jurídicopolítica, os direitos do cidadão e a própria ideia de cidadania não são universais e, por isso, há uma distinção entre cidadãos brasileiros, cidadãos estadunidenses, cidadãos argentinos, etc.

Conforme Sandrini (2006), sob a égide da Constituição da República Federativa do Brasil de 1988, a cidadania é explicitamente erigida à categoria de 
princípio. Caracterizando o estado jurídico do qual desfrutam todos os nacionais e seus efeitos implicam naparticipação do povo nos assuntosde Estado, interagindo, opinando e usufruindo dos trabalhos de Governo.

Cidadania é, portanto, um processo de construção a partir das conquistas adquiridas pelas reivindicações de determinada sociedade regidas por concepções adotadas por um mesmo governo.

Sandrini (2006) explica ainda que a constituição da Cidadania e a construção da nacionalidade não são processos antagônicos nem contraditórios, pelo contrário, são processos sociais complementares. Nacionalidade é vínculo ao território estatal por nascimento ou naturalização; Cidadania é um status ligado ao regime político.

Buscando resgatar as bases históricas sobre dos direitos no Ocidente Europeu, identificamos alguns escritos importantes que devemos mencionar, como os de Platão (427/428 a.C. 348/347 a.C) e de Aristóteles (384-322 a.C).

A obra A República (c. 400 a. C), por exemplo, é um diálogo socrático escrito por Platão, filósofo grego no século IV a.C., que buscava uma definição acerca do que consiste a justiça, em que, discorrendo sobre os regimes políticos e da filosofia ético-política, propõe uma cidade ideal. Platão faz ainda uma interpretação das lutas pela igualdade de direitos, principalmente dasmulheres.

Já na obra Política de Aristóteles, composta por oito livros (I: 1252a 1260b, II: 1261 - 1274b, III: 1275a - 1288b, IV: 1289 - 1301b, V: 1301b -1316b, VI: 1317a - 1323a, VII: 1323b - 1337a, VIII: 1337b - 1342b), o autor também influenciou a constituição dos direitos humanos quando discorre acerca da justiça, da virtude e dos direitos, mostrando como as democracias, oligarquias e tiranias se comportavam em relação a esses pilares.

Dentre as mudanças identificadas entre os escritos do primeiro para o segundo autor supracitados, é que a ideia de perfeição do Estado para Platão, está voltada para a guerra, os negócios e a escravidão. Já para Aristóteles, está voltada para o ócio e a paz, dimensões que gerariam o bem comum.

Esses são exemplos de algumas obras importantes do período anterior ao Cristianismo que começam a dialogar com os conceitos de cidadania, embora ainda sem fazer menção a essa categoria.

Coutinho (1997) revela, porém, que as primeiras teorias sobre o que é ser cidadão, e sobre a Cidadania de fato nasceram na Grécia, nos séculos V e VI, na Era Cristã, correspondendo ao fato de que um número relativamente amplo de pessoas interferia ativamente na esfera pública. Apesar disso, grupos como os escravos, as mulheres e os estrangeiros estavam excluídos dos direitos de 
cidadania.

Ao longo da história, muitos buscaram conceituar essa temática emergindo caminhos para chegarmos a uma experiência mais próxima da realidade.

As notas sobre cidadania e modernidade de Coutinho (1997) já viraram um clássico ao tratarmos o assunto. E para compreender a história iremos utilizá-lo como fim didático. Importante frizar que é com a modernidade que há uma importante ressignificação da cidadania, agora estendida a todos os membros de um dado território nação.

Segundo o autor supracitado, o pesquisador Locke, no século XVII, por exemplo, baseou seu pensamento político na afirmação de que existiam direitos naturais e que esses seriam inalienáveis, como o direito à propriedade, que para ele, é vedado a qualquer intervenção do Estado, mesmo para garantir o direito à vida.

Para Locke, é por meio de um Contrato Social que os indivíduos estabeleceriam as regras de viver em sociedade, mas sem implicar a perda de seus direitos naturais, sobretudo o da propriedade privada.

Essa ideia, porém, pode ser contestada, pois os direitos são fenômenos sociais, resultado de sua construção histórica. Nem mesmo os direitos sociais não podem ser considerados direitos naturais, tais quais aqueles defendidos pelos jusnaturalistas liberais.

Outros autores que sucederam também trouxeram contribuições importantes a respeito dos direitos de Cidadania, como Rousseau (1712-1778), em que a liberdade assume um caráter negativo, pois o homem seria um ser livre, que ao longo do tempo é aprisionado pelas regras do Estado.

Já para Bobbio (1992), somente após a Declaração dos Direitos do Homem e do Cidadão, aprovada pela Assembleia Nacional, em 26 de agosto de 1789, pode se ter a certeza histórica que a humanidade partilha alguns interesses comuns, portanto seria possível crer na universalidade dos valores.

Em 1789, a Declaração dos Direitos do Homem e do Cidadão trouxe os direitos à igualdade, à liberdade, à segurança e à propriedade, como um direito inalienável. Essa última, porém, foi veementemente atacada por diversos autores socialistas como Joseph Proudhon (1840), por ser considerado um direito que corrobora para as desigualdades.

Já em 1864, Karl Marx trouxe, a partir de O Manifesto Comunista (1848), contribuições importantes sob a ótica dos direitos em que orientou união a entre os trabalhadores do mundo na luta por direitos.

No século $X X$, com o fim das duas grandes guerras mundiais, houve 
diversos pronunciamentos, como o "Discurso dos Catorze Pontos", em 1918, do presidente americano Woodrow Wilson, que afirmava o direito dos grupos étnicos à autodeterminação, e também a criação de uma Organização Internacional - Sociedade das Nações (1919) - que visava a garantia da paz e da segurança por meio da cooperação entrehomens.

Esses e outros movimentos levaram, em 1948, à promulgação da Declaração Universal dos Direitos Humanos das Nações Unidas que cooptou ideias liberais, como o reforço do direito à propriedade privada, e também ideias socialistas que, embora a referida Declaração não proponha o fim das classes sociais, incorpora noções voltadas à seguridade social, ao direito ao trabalho, entre outros.

T. H. Marshall (1967, p.63), sociólogo inglês, em seu estudo sobre Cidadania e Classe Social, dividiu, cronológica e linearmente, o conceito que aqui estamos tratando em três partes ou elementos, como podemos observar na figura 2 a seguir.

\section{Civil}

Direitos necessários à liberdade individual (liberdade de ir e vir, liberdade de imprensa, pensamento e fé, direito à propriedade e de concluir contratos válidos e o direito à justiça)

\section{Político}

Direito de participar do poder político como um membro de um organismo investido da autoridade política ou como um eleitor dos membros de tal organismo.

\section{Social}

Direito a um mínimo de bem-estar econômico e segurança de poder participar, por completo, da herança social e levar a vida de um ser civilizado de acordo com os padrões que prevalecem na sociedade (ex.: sistema educacional e serviços sociais)

Figura 2- Pirâmide cronológica da cidadania na Grã-Bretanha.

Fonte: Formulação própria, 2018 a partir de Marshall, 1967.

Conforme apresentado, Marshall revela que, na Inglaterra, primeiro foram conquistados os direitos civis, que são os necessários à liberdade individual (direito de ir e vir, liberdade de imprensa, pensamento e fé, entre outros). Em seguida, teriam sido conquistados os direitos políticos, àqueles referentes a participação em eleições e em votações. E, por fim, os direitos sociais, que 
correspondem à participação na herança social e no bem-estar mínimo.

T. H. Marshall foi um dos primeiros pensadores a apresentar a evolução dos direitos de maneira tão didática. Até hoje esse modelo é uma referência quando tratamos do assunto.

Outro aspecto importante sobre esse referido estudo é que T.H. Marshall atribui à justiça um papel relevante, qualificando instituições como o Legislativo, o Executivo e o Judiciário para haja uma garantia desses direitos de fato.

O autor supracitado afirma que a luta pela cidadania ocorreu na Inglaterra em três momentos distintos e marcou a conquista pelos direitos civis, políticos e sociais.

O primeiro momento teria ocorrido no século XVIII, já no fim do regime feudal, quando burguesia e monarquias absolutistas travavam duras batalhas. Nesse momento, teriam surgido os direitos individuais, isto é, os direitos civis, que se oponham aos ideários feudais, como o direito à propriedade privada, à manifestação religiosa, entre outros, embora esses direitos fossem limitados apenas àburguesia.

No segundo momento, no século XIX, segundo T.H. Marshall, já tendo sido conquistados os direito civis, surgiram os direitos políticos, no qual os trabalhadores poderiam se organizar em sindicatos e em partidos políticos, votar, ser votado, entre outros.

Foi nesse momento de conquista dos direitos políticos que a classe trabalhadora conseguiu se organizar e ampliar a participação na vida política e nos debates, fazendo surgir projetos políticos divergentes entre eles próprios. Surgem, assim, os partidos comunistas e socialistas que propõem revolução em detrimento de reformaspolíticas.

Sentindo-se fragilizada mediante 0 avanço das organizações de trabalhadores, no século $\mathrm{XX}$, a burguesia precisou ampliar o atendimento às exigências de expansão dos direitos sociais. A esse terceiro momento, T.H. Marshall chamou de CidadaniaSocial.

Apesar disso, o autor recebeu duras críticas sobre seu pensamento linear e cronológico do acontecimento dos fatos, sem levar em consideração a complexidade da conquista desses direitos pela classe trabalhadora que faz com que esses ganhos se encontrem e desencontrem ao logo da história.

Além disso, conforme destaca Coutinho (1997), essa ordem cronológica proposta por Marshall não contempla a conquista dos direitos dos demais países.

No caso brasileiro, o processo de conquista da cidadania não seguiu a 
linearidade mencionada por Marshall. Ao contrário, a conquista dos direitos sociais se deu no país inicialmente em dois períodos ditatoriais (o Estado Novo varguista e a Ditadura Militar), quando havia perda de direitos políticos e até mesmo civis.

Entretanto, a conquista desses direitos não abarcou toda população brasileira ao longo da história. Até hoje, a classe trabalhadora e, principalmente, determinados grupos sociais historicamente marginalizados, ainda lutam constantemente para conquistarem seus direitos.

De acordo com Sandrini (2006), que em seu texto dá destaque à conceituação da Cidadania, no caso dos direitos sociais, a necessidade de reconhecimento desses por parte das autoridades políticas e da burguesia, corresponde à garantia de aquisição de um padrão de bem-estar e de seguranças sociais, devem ser garantidos aos cidadãos, entretanto, o que chama atenção é que ele não define claramente em que consiste a referidaCidadania.

Para Dagnino (2004), três elementos constituem a cidadania:

1) Direitos a terdireitos;

2) Os sujeitos sociaisativos;

3) Transformações radicais na sociedade e na estrutura depoder.

Carvalho (2015) apresenta o percurso brasileiro na conquista da cidadania e mostra as camadas da classe trabalhadora que ficaram excluídas de seus direitos. A seguir, faremos um breve resumo sobre como se deu a cidadania no Brasil, por meio das lutas sociais, baseado nos escritos do referidoautor.

No período colonial, "os direitos civis beneficiavam a poucos, os direitos políticos a pouquíssimos, dos direitos sociais ainda não se falava, pois, a assistência social estava a cargo da lgreja e de particulares" (Carvalho, 2015, p.29). Os negros escravos não eram cidadãos, pois lhes faltavam direitos básicos; à população legalmente livre faltava condições para o exercício dos direitos civis, sobretudo a educação; e os senhores, embora livres e com direito ao voto em eleições municipais, faltava-lhes o sentido da cidadania. Somente com a abolição da escravidão, em 1888, é que os negros ex-escravos foram incorporados aos direitos civis, porém, segundo o autor, foi mais formal do que real.

As mulheres também não tinham direito ao voto, mesmo após a Constituição de 1824, que era considerada muito liberal por permitir que os analfabetos, representantes de mais que $85 \%$ (oitenta e cinco por cento) da população, votassem. O obstáculo para a conquista dos direitos sociais no 
Brasil, no período pós-libertação dos negros escravos seria a limitação dos direitos civis, que perduraria até 1930 .

Já na Primeira República (1889 até 1930), houve a Regulação dos direitos políticos, ou seja, só teriam direito ao voto os homens mais abastados. As mulheres conquistaram o direito ao voto após a Revolução de 1930. O movimento operário lutava por direitos básicos, por uma legislação trabalhista e por direitos sociais, como o seguro de acidentes de trabalho e de aposentadoria. É importante destacar que não cabia ao Estado promover a assistência social, as poucas medidas tomadas restringiam-se ao meio urbano e no campo, e era exercida pelos coronéis.

Quanto ao período Vargas (1930 a 1945) verificou-se avanço nos direitos sociais, com vasta legislação trabalhista e previdenciária, como a criação do Ministério do Trabalho, Indústria e Comércio;completada em 1943,coma consolidação das Leis do Trabalho, embora restrita a determinados grupos, como algumas categorias de trabalhadores urbanos.

A origem dos direitos sociais no período Vargas nasceu sob influência dos socialistas pelo mundo. É por isso que, mesmo em um regime autoritário como o que atravessávamos, esses direitos foram conquistados. Era uma forma de ceder à pressão dos trabalhadores e barrar a disseminação dos ideais comunistas no país.

Entretanto, a construção da Cidadania no Brasil também se difere da Europeia no que se refere ao papel do Estado na intervenção social. Na década de 1940, apósaSegunda Guerra Mundial, alguns países da Europa e do continente Norte Americano vivenciaram o Welfare State ${ }^{3}$ ou, em Português, Estado de Bem Estar Social.

No caso brasileiro, Oliveira (2004) chamou de Estado de MalEstar Social. Isso porque aqui não houve expansão dos direitos sociais e nem do "pleno emprego", devido a nossa posição diferenciada na economia mundial e também de nossa peculiaridade histórica, marcada pelo convívio simultâneo de setores industriais modernos e setores tradicionais, juntamente com a economiaagroexportadora.

Os direitos políticos sofreram instabilidade, alternando-se entre ditaduras com o golpe de Vargas, apoiado pelos militares, em 1937- e períodos democráticos, com nova intervenção militar que, dessa vez, derrubou Vargas em

\footnotetext{
${ }^{3}$ Esse trabalho não tem como objetivo dissertar com profundidade o conceito de Welfare State. Para maiores informações ver: GOSTA, Esping-Andersen. As três economias políticas do Welfare State. Lua Nova, no 24. São Paulo Sept. 1991
} 
1945, e deu início à primeira experiência democrática em todo país.

Esse período teve como marco a manutenção das conquistas sociais do período anterior (Vargas) e a garantia dos direitos políticos e civil; embora tenhaexistido a restrição ao direito de greve, houve fortalecimento de movimentos sociais. A novidade desse período foi a promulgação de um Estatuto do Trabalhador Rural, em 1963, que, pela primeira vez, estendia ao campo a legislação social e sindical.

Nesse período, o Brasil viveu a fase de democracia populista de sua política. Segundo Medeiros (2001), o incentivo dos governos populistas à mobilização das massas urbanas em torno dos projetos da burguesia industrial permitiu uma maior organização e participação política do movimento sindical. Com isso, foram introduzidas diversas modificações na legislação trabalhista, embora, como vimos anteriormente, limitada.

No Golpe civil-militar(1964-1985), os direitos civis e políticos foram duramente atingidos pelas medidas de repressão. Alguns avanços no campo dos direitos sociais, como a incorporação de empregadas domésticas (1972) e trabalhadores autônomos (1973) na previdência social, criação do Fundo de Garantia por Tempo de Serviço - FGTS - em detrimento do fim da estabilidade no emprego - e a criação do Ministério da Previdência Social e Assistência Social (1974).

A Redemocratização (pós 1985) foi marcada pela recuperação dos direitos civis, estabelecidos antes do regime militar, a expansão final dos direitos políticos como eleições diretas, voto facultativo dos analfabetos e a ampliação dos partidos políticos, bem como o alargamento dos direitos sociais, como a criação de renda vitalícia para idosos e pessoas com deficiência, conforme critério de renda, elevação da aposentadoria dos trabalhadores rurais para o piso de um salário mínimo, entre outros.

Apesar de todas essas conquistas, persiste a grande desigualdade social e econômica no país. Ainda hoje, muitas dessas conquistas estão em constantes ameaças, em especial àquelas do campo da previdência social que é constantemente acusada de déficit, embora sejam ignoradas nesse cálculo as dívidas corporativas eisenções.

Essa ameaça aos direitos sociais fica muito clara na proposta do atual governo federal da reforma da previdência social, em que está prevista, por exemplo, além do aumento do tempo de contribuição e outras barbaridades, a retirada da garantia constitucional de um salário mínimo a idosos e deficientes, que pode ser reduzido pela metade. 
Já no século XXI, Kerstenetzky (2017), com base nas Pesquisas Nacionais por Amostra de Domicílios do Instituto Brasileiro de Geografia e Estatística, disponíveis no Ipeadata, revela que o decênio entre os anos 2003 e 2014 testemunhou a maior redução histórica da pobreza absoluta em quase quatro décadas no Brasil, desde 1976. Isso se deu pela valorização do salário mínimo e da melhora generalizada do mercado de trabalho brasileiro. Em contrapartida, os avanços em outros setores foram lentos, como investimentos em saúde continuam subfinanciados e a precária qualidade do sistema educacional.

A autora supracitada esclarece, entretanto, que as mudanças na renda não provocaram alterações na estrutura social, conhecida como a classe média no país. Os ganhos de renda das famílias pobres e remediadas não foram suficientes para que ascendessem a recursos discricionários e à segurança econômica. Faltaram outras oportunidades, além das oferecidas pelo mercado de trabalho regulado, os serviços sociais públicos de qualidade, o acesso à riqueza. De um modo geral, os serviços sociais foram negligenciados, principalmente após o congelamento de gastos pelos próximos vinte anos ${ }^{4}$.

Nesse tópico, quisemos dar evidência à luta dos movimentos sociais pelas conquistas dos direitos de cidadania, ainda que tenha sido muitas vezes apagada ao longo da história. Até hoje é ela quem nos permite avançar para conseguirmos novos direitos e para que não perca os que temos. Não é uma garantia, é esforço diário e unido em prol da liberdade e daequidade.

Adiante, veremos como o direito à Saúde se apresenta no rol dessas conquistas e todas as prerrogativas a ela inerentes.

\section{2.}

\section{A Política de Saúde como direito de Cidadania no Brasil e a luta do Serviço Social por essa conquista}

Durante muito tempo, o conceito de doença (e de saúde) teve relação com aspectos sobrenaturais, de ação de maus espíritos ou de cóleras divinas, fato que se estendeu até a idade média.

O período de acumulação capitalista trouxe grande interesse na colonização dos países periféricos, ao mesmo tempo em que surgiam as preocupações com as doenças transmissíveis, e, a partir daí, a preocupação em estudá-las e curá-las.

\footnotetext{
${ }^{4}$ A PEC 241 ou PEC 55, emenda constitucional aprovada em dezembro de 2016, na Câmara dos Deputados e o Senado, congela as despesas do Governo Federal, com cifras corrigidas pela inflação, por até 20 anos.
} 
O século XIX foi marcado, nesse sentido, por propostas na área sanitária, uma resposta às reivindicações da classe operária que questionava a pobreza e as condições a que estava exposta.

Era uma tentativa de responder às mudanças sociais e às práticas de saúde observadas com o desenvolvimento da urbanização e da industrialização. De qualquer modo, não havia ainda um conceito universalmente aceito do que erasaúde.

Segundo Fernandes, et al (2011), ao longo do século XX, foram formuladas propostas para o controle de doenças transmissíveis e construídos conceitos e terminologias como "extinção", "eliminação" e "erradicação". Isso porque as doenças transmissíveis assumiram significado importante para a saúde pública internacional nesse período, com repercussão nas relações entre os países, principalmente diante da ampliação do contato internacional entre estes e do trânsito de pessoas e de enfermidades, facilitado pelastecnologias.

Nesse período, a saúde emerge como questão social no bojo da economia exportadora cafeeira, refletindo o avanço da divisão social do trabalho, ou seja, a emergência doproletariado.

Segundo Bravo (2000), na década de 1920, foram colocadas em pauta as questões de higiene e saúde do trabalhador, sendo tomadas algumas medidas que se constituíram no embrião do esquema previdenciário brasileiro, sendo a mais importante a criação das Caixas de Aposentadoria e Pensões (CAPs) em 1923 - conhecida como Lei Elói Chaves - financiadas pela União, pelas empresas empregadoras e pelosempregados.

Os trabalhadores vinculados ao setor urbano do complexo exportador foram os primeiros a conquistarem a organização das Caixas em suas empresas, devido sua organização política, sendo primeiro os ferroviários em 1923, em seguida os estivadores e os marítimos em 1926. Os demais só o conseguiram após1930.

A política de saúde formulada nesse período era de caráter nacional, organizada em dois subsetores: o de saúde pública e o de medicina previdenciária, que surgiu na década de 1930, com a criação dos Institutos de Aposentadorias e Pensões (IAPs), que pretendeu estender para um número maior de categorias de assalariados urbanos os seus benefícios como forma de "antecipar" as reivindicações destas categorias e não proceder uma cobertura maisampla.

Segundo Bravo (2011), no final dos anos 1940, com o Plano Salte, que envolvia as áreas de Saúde, Alimentação, Transporte e Energia, a Saúde foi 
posta como uma de suas finalidades principais. O plano apresentava previsões de investimentos de 1949 a 1953, mas não foiimplementado.

A estrutura de atendimento hospitalar de natureza privada, com fins lucrativos, já estava montada a partir dos anos 1950 e apontava na direção da formação das empresas médicas. A corporação médica ligada aos interesses capitalistas do setor era, no momento, a mais organizada e pressionava o financiamento através do Estado, da produção privada defendendo claramente aprivatização.

Na década de 1960 e 1970 um novo padrão de serviços médicos previdenciários foi implantado, com prioridade de contratação de serviços de terceiros, em detrimento dos serviços próprios da previdência, cabendo ao Estado propiciar o crescimento e a expansão da iniciativa privada, o que tornou a prática médica altamente lucrativa.

Segundo Bravo (2011), no período de ditadura civil-militar, iniciada em 1964, ainda prevalecia a dicotomia saúde pública x saúde curativa, sendo dada pouca importância às medidas de atenção coletiva à saúde da população.

A autora supracitada considera ainda que, durante a década de 1960, a redução dos gastos em saúde pública foi uma decisão política e não se pautou por indicadores sociais, que apresentavam crescimento em áreas como mortalidade.

Paralelamente foi nesse período que um novo padrão de organização de serviços médicos previdenciários foi implantado, como: prioridade na contratação de serviços de terceiros, financiamento a hospitais privados e credenciamento para a compra de serviços e convênios com empresas, numa clara articulação entre a previdência e o setor privado.

Bravo (2011) destaca ainda que as reformas realizadas na estrutura organizacional, no período de 1974 a 1979, que culminariam na política nacional de saúde, não conseguiram reverter a ênfase da política de saúde, caracterizada pela predominância da participação da previdência social, por meio de ações curativas, comandadas pelo setor privado.

Ainda segundo a autora supracitada, a organização dos setores progressistas de profissionais de saúde pública, denominada posteriormente de movimento sanitário, iniciou- se em meados dos anos 1970. Os estudos daquele período relacionavam os efeitosperversos da economia centralizadora que agravou as condições de vida e de higienie da população com as transformações ocorridas no setor saúde.

É também nesse período que observamos a presença do Serviço Social 
como categoria que está presente na luta pela classe trabalhadora. Conforme explica Bravo (2011), isso ocorre desde o processo de renovação (Movimento de Reconceituação), a partir da década anterior. A profissão está inserida no rol do mercado de trabalho, que incluiu as mulheres na educação superior e as casadas nas atividades públicas, articulada ao movimento feminista daqueleperíodo.

Essa ação provocava um questionamento para os assistentes sociais e outros profissionais de saúde sobre suas demandas frente às ditaduras na América Latina e seus interesses econômicos e sociais que iam de encontro aos interesses da população, incluindo àqueles referentes às questões desaúde.

E é no ano de 1978, na Conferência de Alma-Ata - no atual Cazaquistão que a discussão sobre os Determinantes Sociais de Saúde (DSS) ganha notoriedade, a partir da ampliação do conceito de saúde. Apesar disso, paralelamente, reformulava-se a saúde como bem privado. É o modelo médicoassistencial privatista, identificado como modelo médico hegemônico, hospitalocêntrico ou biomédico, em que a prática profissional assenta- se na assistência ao indivíduo doente e opera com uma compreensão biológica do fenômenosaúde-doença.

Segundo Buss e Filho (2006), a Conferência de Alma-Ata, no final dos anos 1970 , e as atividades inspiradas no lema "Saúde para todos no ano 2000" recolocam em destaque o tema dos determinantes sociais.

Bravo (2011) revela que os valores conquistados a partir da reforma sanitária, que teve início na década de 1970, partiu de uma perspectiva da Saúde Pública, com base em um estudo sobre a totalidade social que, embora extremamente complexa, busca analisar a realidade concreta identificando a correlação de forças, a distensão política e a realidade histórica. A história da Saúde Pública no Brasil é marcada por muita luta antes e após a reforma sanitária que culminou na Constituição Federal da República de 1988.

Carvalho (2013) destaca alguns protagonistas fundamentais para essa construção, sendo eles:

1) Movimentos populares - Destacam-se nessa luta social do cidadão três grandes protagonistas: os movimentos populares, as associações de bairros e vilas e a Igreja Católica.

2) Universidades - Outro protagonista veio das faculdades de medicina com dois momentos inovadores: o primeiro, com a necessidade de colocar os estudantes em contato com arealidade local. Desenvolveu projetos de integração docente assistencia. O segundo, a transformação dos antigos departamentos de 
higiene em departamentos de medicina social, mais engajados com a realidade.

3) Partidos políticos progressistas - Na década de 1970, estava o Brasil colocado dentro dos limites do bipartidarismo restrito. Mesmo com essa limitação, o partido mais progressista - MDB - que representava alguma resistência à ditadura, buscava o trabalho junto com as comunidades, na periferia dos grandes centros urbanos e em algumasprefeituras.

4) Prefeituras com bandeiras progressistas - Os municípios, por estarem mais perto das necessidades da população, carregavam o problema e a angústia do que não se fazia em saúde e prejudicava sua população. Nesse cenário, em 1976, surgiram várias administrações municipais com a proposta de se comprometer com o social e não ser apenas prefeituras tocadoras de obras. Assim se definiu e assim surgiu o que mais tarde se denominou como movimento municipalista desaúde.

Nesse momento, segundo Bravo (2011), a organização de setores progressistas de profissionais de saúde pública (movimento sanitário) no Brasil, iniciada em 1970, promove um crescimento considerável de encontros e de produção teórica que, por sua vez, enfatizaram a análise do setor da saúde, relacionando-os com os efeitos perversos da economia centralizadora, que agravou as condições de vida e de higidez da população, dificultando o seu acesso a bens essenciais, tornando-a mais vulnerável às enfermidades e outros danos à saúde.

$\mathrm{Na}$ década de 1990 retoma-se a discussão de saúde para todos. O conceito de DSS é bastante generalizado e entende que as condições de vida e de trabalho dos indivíduos e grupos estão relacionadas com a situação de saúde.

O predomínio do enfoque da saúde como um bem privado desloca novamente o pêndulo para uma concepção centrada na assistência médica individual, a qual, na década seguinte, com o debate sobre as "Metas do Milênio ${ }^{5 ",}$ novamente dá lugar a uma ênfase nos determinantes sociais que se afirmam com a criação da Comissão sobre Determinantes Sociais da Saúde da OMS, em 2005.

\footnotetext{
${ }^{5}$ Metas do Milênio foi um documento que consolidou várias metas estabelecidas nas conferências mundiais ocorridas ao longo dos anos 1990, estabelecendo um conjunto de objetivos para 0 desenvolvimento e a erradicação da pobreza no mundo - os chamados Objetivos de Desenvolvimento do Milênio (ODM) - que deveriam ser adotados pelos estados membros das Nações Unidas, que moveriam esforços para alcançá-los até 2015. Tratava-se de Oito objetivos gerais: erradicar a extrema pobreza e a fome, atingir o ensino básico universal.Promover a igualdade de gênero e a autonomia das mulheres, reduzir a mortalidade infantil,melhorar a saúde materna,combater o HIV/AIDS, a malária e outras doenças, garantir a sustentabilidade ambiental e estabelecer uma parceria mundial para odesenvolvimento.
} 
Em 2006, foi criada, então, a Comissão Nacional sobre Determinantes de Saúde (CNDSS), vinculada a Fundação Oswaldo Cruz (Fiocruz), por meio de decreto presidencial, a partir de um movimento internacional,composta por dezesseis especialistas e personalidades. Segundo a cartilha da própria CNDSS, "sua criação e composição expressam o reconhecimento de que a saúde é um bem público, a ser construído com a participação solidária e de todos os setores da sociedade brasileira".

Há diversos esquemas que pretendem demonstrar as relações entre os diversos fatores estudados por meio desses diversos enfoques. Esse apresentado abaixo é o modelo de Dahlgren e Whitehead que inclui os DSS dispostos em diferentes camadas, desde uma camada mais próxima dos determinantes individuais até uma camada distal, onde se situam os macrodeterminantes.

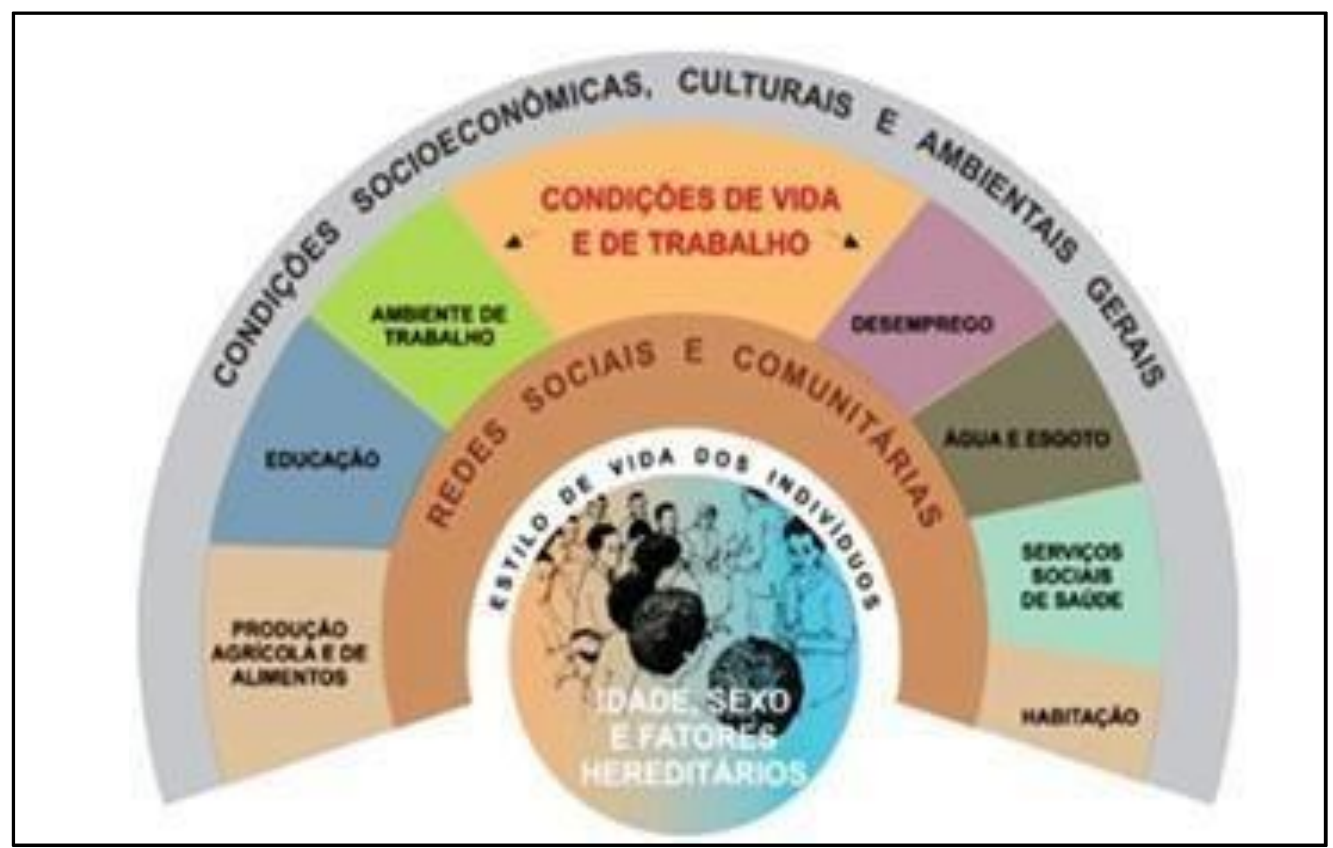

Figura 3- Modelo de DSS adotado pela CNDSS - Brasil.

Fonte: CNDSS, 2008 (apud Dahlgren; Whitehead, 1991).

Buss e Filho (2007) explicam que a base desse modelo apresenta os sujeitos com suas características individuais de idade, de sexo e os fatores genéticos que, evidentemente, exercem influência sobre seu potencial e suas condições desaúde.

Em seguida, explicam que, na camada imediatamente próxima, aparecem o comportamento e os estilos de vida individuais que, muitas vezes, são entendidos apenas como de responsabilidade individual, dependentes de opções feitas pelo livre arbítrio das pessoas, mas, na realidade, podem também 
ser considerados parte dos DSS, já que essas opções estão fortemente condicionadas por determinantes sociais, como informações, propaganda, pressão dos pares, possibilidades de acesso a alimentos saudáveis e espaços de lazer etc.

Dando continuidade, destacam a influência das redes comunitárias e de apoio como de fundamental importância para a saúde da sociedade como um todo, dependendo da coesão social.

No próximo nível estão representados os fatores relacionados a condições de vida e de trabalho, disponibilidade de alimentos e acesso a ambientes e serviços essenciais, como saúde e educação.

Finalmente, no último nível estão situados os macrodeterminantes relacionados às condições econômicas, culturais e ambientais da sociedade e que possuem grande influência sobre as demais camadas.

Assim, os DSS, para a Comissão Nacional sobre Determinantes de Saúde, são fatores sociais, econômicos, culturais, étnicos/raciais, psicológicos e comportamentais que influenciam a ocorrência de problemas de saúde e seus fatores de risco na população (Buss e Filho, 2006).

As diversas definições de determinantes sociais de saúde expressam, com maior ou menor nível de detalhe, o conceito, atualmente, bastante generalizado de que as condições de vida e trabalho dos indivíduos e de grupos da população estão relacionadas à sua situação de saúde (Ibidem, 2007). Ou, de acordo com a Organização Mundial da Saúde são as condições sociais em que as pessoas vivem e trabalham.

A promoção da saúde encontra nesse cenário um terreno fértil, favorável para sua disseminação como estratégia, numa combinação de diretrizes com mudanças no modelo de atenção. Ela ganhou espaço no debate nacional no final dos anos 1990 e foi editada como política pela primeira vez no ano de2006.

O fato é que essas ações que propõem a intervenção na "vulnerabilidade" a partir da Promoção da Saúde, desconsideram que o próprio modo de produção capitalista gera as desigualdades sociais.

A partir disso, cai na perspectiva de culpabilização dos sujeitos que precisariam buscar melhores condições de vida por meio da colaboração entre as classes, negando o conflito existente entre elas, por possuírem interesses opostos.

Souza, et al (2013, p.47) argumentam que, apesar de o conceito de DSS não questionar o modo de produção da ordem capitalista e de propor ações de saúde de maneira fragmentada e por intermédio de reformas na ordem societária 
vigente, "a busca por uma concepção de saúde que não seja meramente biológica permite, ao menos, um espaço de discussão sob perspectivas mais amplas". Dessa forma, entendemos que o enfoque da saúde está para além das razões definidas comoDSS.

Muitas críticas têm sido estabelecidas a essa abordagem da OMS sobre os determinantes sociais da saúde. Essas críticas têm sido articuladas especialmente por meio de debates no interior da saúde coletiva e da medicina social latino-americana, circulandoao redor da diferenciação entre determinante sociais da saúde e a determinação social do processo saúde-doença.

Segundo Pettres e Ros (2018) a determinação social da saúde e a promoção da saúde foram influenciadas pelas ideias revolucionárias do século XIX, incluindo Marx, Engels e Virchow e foram amplamente discutidas entre os países latino-americano. Estas influências enfatizaram que os modos de produção geravam doenças. Nesse sentido, fortalece-se a mudança contra hegemônica da lógica de acumulação docapital.

O Movimento da Nova Promoção da Saúde ancorada na perspectiva da determinação social do processo saúde-doença estimula uma análise crítica quanto aos enfrentamentos da influência do processo de trabalho e relações sociais de produção hegemônicos, indo além dos estilos e modos de vida dapopulação.

De fato, a Promoção da Saúde também é um campo de disputa dentro da Saúde Coletiva entre a vertente positivista e outra de contribuição socialista. De todo modo, é um importante espaço para discussão na perspectiva do conceito ampliado de Saúde.

Assim, a saúde, como condicionante do acesso ao saneamento básico, à habitação, ao esporte, à alimentação, etc., ultrapassa o conceito desses determinantes sociais. Ela está atrelada ao processo de trabalho envolto no modo de produção na qual está inserida. A saúde, para nossa sociedade, é, portanto, expressão da "questão social" da qual nos referimosanteriormente ${ }^{6}$.

\footnotetext{
${ }^{6}$ Santos (2012) entende que "questão social" é um conjunto de expressões das desigualdades oriundas do modo de produção capitalista que formam e desenvolvem a classe operária a partir do momento histórico em esta entra no cenário político da sociedade exigindo seu reconhecimento como classe por parte do Estado e do empresariado, mudando as formas de "solidariedade" e "coesão social. Autores contemporâneos e estudiosos sobre a temática, como Santos (2012) e lamamoto e Carvalho (1995), não admitem haver mais de uma "questão social". Nas obras citadas, os autores concordam com o conceito de que ela é um conjunto de expressões das desigualdades oriundas do modo de produção capitalista que formam e desenvolvem a classe trabalhadora, queentra no cenário político, se reconhece como classe, mudando as formas de solidariedade. A "questão social", então, é a soma da organização da luta dos trabalhadores na defesa de seus interesses de classe e na busca pela reprodução de vida. Em suma, trata-se do produto do pauperismo, gerado como enfrentamento pela da luta de classes. Como exemplo dessas
} 
Santos (2012) lembra que a pauperização, considerada por ela a expressão máxima da "questão social", remete a outros indicadores sociais (saneamento básico, habitação, educação, entre outros), que determinam, por sua vez, os indicadores de saúde.

Desta forma, a saúde, no processo de acumulação capitalista, é por ela determinada. Portanto, pensá-la como um resultante dos processos sociais e propor medidas reformistas, contribuem para amenizar seus impactos na sociedade capitalista, mas são insuficientes. Seria necessário alterar o modo de produção.

É preciso lembrar que, as implicações deste contexto, se impõem aos profissionais de Serviço Social de forma diversa. Em primeiro lugar, apesar desta categoriapossuirautonomia, que pode fornecer alguma direção política às suas ações, não deixa de estar inserida no estatuto de assalariamento.

Por outro lado, as organizações empregadoras também podem Ihes atribuir metas a atingir, além de definir suas relações de trabalho, condições e imputar tarefas altamente questionáveis a essa categoria, indo de encontro às atribuições e prerrogativas destinadas a estes profissionais legalmente.

Bravo (2011) revela que a participação dos assistentes sociais da área da Saúde na reforma sanitária buscou contribuir com a viabilização da participação popular, da democratização das instituições, da elevação da consciência sanitária e da ampliação dos direitos sociais.

Ainda segundo a autora supracitada, o movimento sanitário, que buscou a ampliação dos espaços nas instituições públicas, pautou-se em Gramsci, com as contribuições de Berlinguer, que propunha a conquista de posições no Estado, articulada ao avanço do movimento popular.

Entretanto, a alteração de correlação de forças do governo Sarney, impediu a consolidação da reforma sanitária brasileira, colocando o risco de transformar as conquistas obtidas em mera modernização (mais administrativa e menos sanitária).

Com a inclusão do Sistema Único de Saúde na Constituição Federal de 1988 e sua efetivação a partir da Lei no 8080/90, a saúde no Brasil adotou as seguintes diretrizes e os seguintes princípios: universalidade, igualdade, equidade, integralidade, intersetorialidade, direito à informação, autonomia das pessoas, resolutividade e base epidemiológica.

A saúde foi instituída na Carta Magna juntamente com a Assistência Social

expressões, podemos citar a flexibilidade/precariedade do mercado de trabalho os postos de trabalho no Brasil) e o desemprego 
e a previdência social como tripé da Seguridade Social, pois, como bem destaca Simões (2010, p.103): "[...] são correlacionadas, visando a assegurar direitos sociais que, em face de sua complementaridade social, convergem para a finalidade constitucional da garantia da estabilidade da própria sociedade".

Após muitas lutas travadas pela classe trabalhadora e movimentos da sociedade civil, a Constituição Federal de 1988 veio como base para um ensaio ao Estado de Bem Estar Social, o qual países periféricos como o Brasil não haviamvivido.

A referida constituição federal trouxe a saúde como direito de todos e dever do Estado e a Lei 8.080 de 19 de setembro de 1990, dispôs sobre as condições para promoção, proteção e recuperação da saúde, a organização e o funcionamento dos serviços correspondentes (Brasil,1990).

Os princípios Constitucionais do SUS incluem a universalidade, a integralidade da atenção, incluindo todas as ações necessárias à promoção, à prevenção, ao tratamento e à reabilitação.

Bravo (2011) chama atenção que o texto aprovado na Constituinte, com relação à Saúde, atende, em grande parte, às reivindicações do movimento sanitário, prejudica os interesses empresariais do setor hospitalar e não altera a situação da indústria farmacêutica.

O direito universal à saúde e o dever do Estado, acabando com discriminações entre segurado/não segurado, rural/urbano;

- As ações e serviços de saúde passaram a ser considerados de relevância pública, cabendo ao poder público sua regulamentação, fiscalização econtrole;

- A constituição de Sistema Único de Saúde, integrando todos os serviços públicos em uma rede hierarquizada, regionalizada, descentralizada e de atendimento integral, com participação dacomunidade;

- A participação do setor privado no sistema de saúde deverá ser complementar, preferencialmente com entidades filantrópicas, sendo vedada a destinação de recursos públicos para subvenção a instituições com fins lucrativos. Os contratos com entidades privadas portadoras de serviços far-se-ão mediante contrato de direito público, garantindo ao Estado o poder de intervir nas entidades que não estiverem seguindo os termoscontratuais;

- A proibição da comercialização de sangue e seusderivados.

Contudo, nos anos 1990, a "Pátria amada" iniciou seu processo de integração à ordem econômica mundial, com práticas neoliberais que se impõem às políticas públicas de proteção social e à universalização da seguridade social 
brasileira, desenvolvendo o que Oliveira (2004) denominou como "Estado de mal-estar social".

Mota (2006) vem lembrar que este processo contribui para a transformação dos direitos sociais em negócios, como vem ocorrendo com a saúde, a previdência e a educação. No caso da Saúde, por exemplo, segundo Fortes(2017):

\begin{abstract}
O artigo 199 da Constituição Federal abriu precedentes para a oferta de serviços de saúde, por meio de instituições privadas, ainda que de forma complementar. Já no artigo $1^{\circ}$ da LOS- Lei Orgânica da Saúde -, reforça a participação de entidades particulares quando regulamenta que as ações e serviços de saúde podem ser executados por pessoas naturais ou jurídicas de direito público ou privado. Isso se deu porque, apesar das conquistas de 1988, a entrada do neoliberalismo no Brasil, iniciou um processo de desmonte das políticas públicas, inclusive a de Saúde e minimizou as responsabilidades do Estado, transferindo-as para a sociedade civil através de Organizações Sociais e de entidades filantrópicas. Cabe lembrar também, que a Constituição de 1988 e a inserção do SUS no seu bojo não foi uma decisão absolutamente consensual, houve sim uma correlação de forças e esse lastro foi deixado pelos contrários a existência de um sistema público e universal (Fortes, 2017, p. 303).
\end{abstract}

A mercantilização da saúde se dá, além da rede privada e da entrada dos planos de saúde ${ }^{7}$, também pelo gerenciamento dos hospitais públicos, graças às Organizações Sociais de Saúde (OSS), sem fins lucrativos e com interesses duvidosos, a partir de 1997.

Correia e Omena (apud Correia, 2013) afirmam que o setor privado da saúde tem se expandido tanto no livre mercado, como por dentro do SUS, por meio de compras de serviços privados "complementares" e pelo repasse da gestão do SUS.

O paciente que chega em uma unidade do Sistema Único de Saúde (SUS), muitas vezes, traz consigo muito mais que uma demanda pontual e imediata. Ele carrega diferentes expressões da questão social, fruto do processo de acumulação capitalista e das relações a ela intrínsecas.

São questões que devem ser tratadas de forma articulada pela Assistência Social, pela Previdência Social, pelo Poder Judiciário e outros setores. Como bem salienta o Manifesto "O SUS pra valer: Universal, humanizado e de qualidade ${ }^{8}$, , de 2006:

\footnotetext{
7 É importante lembrar que este é um processo de longa data. A ditadura militar, por exemplo, apesar de ter "ampliado" direitos, dentro dos quais o previdenciário e os de Saúde e de Assistência Social, isto se deu assentado sob uma lógica perversa de beneficiamento do privado em detrimento do público

${ }^{8}$ Segundo o próprio manifesto, trata-se de documento preparado pelo Fórum da Reforma Sanitária Brasileira,integrado por Abrasco (www.abrasco.org.br), Cebes (cebes@ensp.fiocruz.br), Abres (www.abres.fea.usp.br), Rede Unida (www.redeunida.org.br) e Ampasa (www.ampasa.org.br), e
} 
Não se pode esperar que o setor de saúde seja capaz de responder à demanda crescente de atenção provocada por uma sociedade desigual, injusta e cada dia mais violenta, cuja sociabilidade se encontra rompida e na qual o outro é visto como ameaça. As consequências são a perda da coesão social, expressa não apenas por milhares de mortes e internações, mas também no sofrimento mental, na insegurança e no desalento, que seriam evitáveis onde predominassem uma cultura de paz e justiça social (Fórum da Reforma Sanitária Brasileira, 2006).

O relatório final da Comissão Nacional sobre Determinantes Sociais da Saúde (2008) mostra que para diminuir a desigualdade social, a política de saúde deve atuar junto às diferenças sociais como as relacionadas ao mercado de trabalho, à educação e à seguridade social, aos grupos que vivem em condições de habitação insalubres, trabalham em ambientes pouco seguros ou estão expostos a deficiências nutricionais, entreoutros.

Ao assistente social cabe, portanto, identificar as demandas trazidas pelo usuário que envolvem as expressões da questão social e que, inclusive, podem afetar a saúde do referido. Inserido na divisão social e técnica do trabalho e movido por procedimentos teóricos e metodológicos, o Serviço Social pode conhecer e intervir narealidade.

Desta forma, como retrata Mota et. al (2008) ao atender as necessidades imediatas e mediatas da população, o Serviço Social na saúde interfere e cria um conjunto de mecanismos que incidem sobre as principais contradições do sistema de saúde pública no Brasil.

A partir do exposto, há que se traçar estratégias para atuação profissional, como abordaremos no capítulo seguinte.

está em discussão com a Frente Parlamentar da Saúde, com outras entidades dos setores de saúde e de educação e com a sociedade. 


\section{3 Estratégias para prática dos assistentes sociais na política de Saúde}

\section{1. O Serviço Social na Saúde: inserção e prática profissional}

Nesse tópico, vamos traçar um breve histórico sobre a trajetória do Serviço Social na Política de Saúde brasileira e seus desafios atuais. É importante lembrar que o assistente social só se realiza como trabalhador mediante a venda de sua força de trabalho, por intermédio de condições e relações de contratos trabalhistas que definirão sua jornada de trabalho, suas funções e suas atribuições, de acordo com a legislação trabalhista em vigor.

Por consequência da lógica do mercado e da crise capitalista estrutural que vivenciamos, o exercício profissional sofre mudanças nas suas condições de empregabilidade como a ameaça do desemprego, a redução salarial, as mudanças nos parâmetros legais, etc.

Na década de 1940, devido à elaboração de um conceito de saúde que trouxe os aspectos biopsicossociais como seus determinantes, a saúde foi a área que mais absorveu o profissional de Serviço Social no Brasil, conforme nos revelam Martini et al (2013).

O início da década de 1960 foi marcado por uma racionalidade burocráticoadministrativa em meio à modernização conservadora que, segundo Bravo (2011, p.119), engendrou um mercado nacional de trabalho para os assistentes sociais, com a reestruturação do Estado, racionalizado para gerenciar o desenvolvimento em proveito dos monopólios, com a elaboração de políticas setoriais e toda a malha organizacional encarregada de planejá-las e executálas, que sofreu uma série de reformas.

Assim, a modernização conservadora (Netto, 1989) surgiu como estratégia utilizada pelos profissionais de Serviço Social, diante do golpe de 1964, redefiniu a base de legitimidade profissional a partir das novas exigências do mercado. Bravo (2011) revela que é na década 1960 que a busca dos assistentes sociais por um novo status profissional ganhou força, assim como o surgimento de diversas propostas teórico-metodológicas, o movimento pela laicização do Serviço Social, os questionamentos da posição conservadora assumida majoritariamente pelos assistentes sociais, etc. 
Em 1967, segundo Bravo (2011), o Serviço Social foi regulamentado nos órgãos de assistência médica do complexo da previdência e previa as seguintes ações:

- Individual, de caráter preventivo ecurativo;

- $\quad$ Grupal, de caráter educativo-preventivo ecurativo;

- Comunitária, para mobilização de recursos e reintegração dos pacientes à família e aotrabalho.

A década de 1970 foi marcada pelo surgimento do Movimento Sanitário ${ }^{9}$ e da abertura de novas direções teórico-metodológicas do Serviço Social. Nesse período, na profissão, passou a promover a (intenção de) ruptura (Netto, 1989), com a vertente modernizadora que prevalecia até então.

Em 1972, foi aprovado o Plano Básico de Ação do Serviço Social na Previdência, que tinha por objetivo definir a política de ação do assistente social, por meio de regras que especificavam seus objetivos e sua clientela. Bravo (2011) apresenta as ações enfatizadas no plano, sendoelas:

- Recuperação de segurados incapacitados, focalizando os fatores psicossociais e econômicos que interferem no tratamento médico e na manutenção dosbenefícios;

- Atuação integrada na clínica pediátrica, centrada nos fatores psicológicos, sociais e econômicos responsáveis pelo alto índice de morbidade e mortalidadeinfantil;

- $\quad$ Foco no sistema de proteção e recuperação da saúde, incidindo sobre os fatores psicossociais e econômicos que interferem no tratamentomédico.

Diante desse contexto, observamos a inserção do Serviço Social na saúde a partir da centralidade no modelo biomédico (curativo), com ações afastadas da saúde pública.

Bravo (2011) revela que em 1974, os assistentes sociais começaram a se organizar enquanto categoria e reagiram no âmbito sindical e de ensino, efetivando seu processo de consolidação acadêmica em 1980.

A autora citada anteriormente aponta que esse período foi permeado pelo discurso do compromisso com a classe trabalhadora, mas não houve

\footnotetext{
${ }^{9}$ Movimento da sociedade civil (sindicatos, partidos e associações) dos anos 1970 e 1980 que lutou pela Reforma Sanitária no Brasil que, segundo Bravo (2011), se insere no quadro mais geral da luta de classes no país e só pode ser efetivada por um Estado democrático. Foi promotor de significativos avanços, como a modernização setorial, a realocação de despesas em favor do setor público e a colocação na cena política da noção de direito social universal, como a tematização, Saúde: direitos de todos e dever doEstado.
} 
rebatimento na construção de alternativas para a ação do profissional em nível institucional, assim, a categoria não conseguiu alterar a orientação dos projetos de ação profissional. A autora citada faz críticas a continuidade da direção "modernizadora" em que se manteve a prática profissional e revela.

Na saúde, os profissionais continuavam distantes da reflexão e aprofundamento teórico ocorrido no Serviço Social. Os adeptos da vertente "intenção de ruptura" não conseguiram definir um novo padrão de intervenção profissional com estratégias teórico-político- ideológicas que pudessem colocar o Serviço Social em outro patamar, deslocando-o da execução terminal das políticas de saúde. Um dos indicativos dessa afirmativa se refere aonão engajamento dos assistentes sociais no "movimento sanitário", como já apontamos quando da análise das políticas de saúde nas conjunturas em debate. Essa exclusão foi determinada por condições internas e externas à profissão, [...], mas teve consequências práticas significativas, pois o profissional não participou da elaboração e estratégias e táticas forjadas pelos representantes do "movimento sanitário", de forma a nortear sua ação, ampliando-a em diversos níveis: elaboração da política, contato parlamentar, articulação sindical, produção teórica na área (Bravo, 2011, p.150).

A intenção de ruptura, segundo Netto (1989), surge para romper com o tradicionalismo, já que tinha um caráter de oposição à autocracia burguesa e à perspectiva modernizadora. Também teve uma aproximação (ainda que enviesada) com a teoria marxista se desenvolvendo no círculo acadêmico.

É nessa perspectiva de valorização do pensar as ações do Serviço Social como uma categoria profissional que ela intervém na realidade à luz do pensamento teórico crítico, que compreendemos ser importante pesquisas, como a nossa, que apresentam novas possibilidades para o pensar e o fazer profissional, compreendendo nosso lugar na divisão social e técnica do trabalho, mas com o objetivo de romper com modelos tradicionais de intervenção que busquem a manutenção do status quo.

Dessa forma, Vasconcelos (2012) entende que:

A superação da dicotomia entre teoria e prática, como um processo que se põe permanentemente para o conjunto da categoria dos assistentes sociais que tem como objetivo uma ruptura com as práticas conservadoras e de dominação, se depende da elaboração de um projeto de profissão, a partir de uma análise criteriosa da realidade, que referencie e fundamente uma formação e uma ação profissional crítica e consciente, demanda uma articulação projetada, permanente e sistemática entre academia e meio profissional. Isso vem em resposta à necessidade de superar o modo positivista de pensar e agir no Serviço Social, em que aos assistentes sociais cabe intervir na realidade e à academia e/ou ao debate profissional cabe a produção do conhecimento. Aos interessados em romper com essa dicotomia - seja no debate, na formação ou no exercício profissional - coloca-se a necessidade de apropriação e interlocução permanente com o marxismo (Vasconcelos, 2012, p. 126). 
É na década de 1970 que o debate sobre a intersetorialidade, como tentativa de potencializar as ações de saúde, ganha maior destaque, visto que seus determinantes e condicionantes são trabalhados por políticas específicas.

França e Cavalcanti (2013) lembram que apesar da inclusão da diretriz da intersetorialidade na Lei Orgânica de 1990, que prevê a integração intersetorial com a intrasetorial da rede assistencial, esta segunda assume maior prioridade na agenda institucional, o que retrata a noção prevalente entre gestores e profissionais sobre o conceito de integralidade ademais as estratégias implantadas para a garantia desse princípio priorizam a articulação entre os diferentes níveis de atenção à saúde.

A implementação da intersetorialidade em saúde consiste em incorporar pensamentos e concepções que informem uma nova maneira de planejar, executar econtrolar a prestação de serviços voltados para uma nova prática Sanitária (Ferreira e Silva, 2005).

Segundo os autores citados anteriormente, a estratégia da intersetorialidade pode ser considerada como uma forma de implementação de uma política mediante o comportamento de um autor (indivíduo, grupo, instituição), cujo propósito é adquirir certa liberdade de ação, que lhe permita ganhar espaço de manobra para implementar os objetivosbuscados.

A estratégia da qual tratamos anteriormente pode ser pensada também em situações como as do momento da alta hospitalar, em que o sujeito deve estar envolvido na decisão de sua saída daunidade.

No Brasil, as conquistas dos anos 1980 representam uma importante reforma democrática e a institucionalização da política social com a Constituição Federal de 1988, que trouxe a seguridade social inspirada no modelo Beveridgiano; e os direitos previdenciários seguindo o modelo Bismarckiano, surgindo, portanto, o trinômio: Saúde, Assistência Social e Previdência Social.

No âmbito da Saúde, Martini et al (2013) revelam que as inovações trazidas na Constituição Federal de 1988 influenciaram na superação do modelo centrado na doença e nas ações curativas e na construção de um novo modelo de assistência à saúde, voltado para sua promoção. Esse novo modelo requisitou um trabalho multiprofissional e, com isso, o assistente social passou a ter maior importância na área da saúde, exigindo um profissional capacitado para atuar nas múltiplas expressões da questão social originadas nas relações sociais que afetam a saúde. É a partir dessa compreensão que o profissional de Serviço Social passa a ser contratado como um dos promotores na consolidação do Sistema Único de Saúde e de seus princípios e como articuladores da saúde 
com as demais políticaspúblicas.

Costa (2008) explica que, a partir dos anos 1990, com a implementação do Sistema Único de Saúde, mudanças de ordens tecnológica, organizacional e política passaram a exigir novas formas de organização do trabalho na saúde, determinadas pela hierarquização por nível de complexidade, descentralização e democratização do sistema, imprimiram novas características ao modelo de gestão e atenção e, portanto, aos processos de trabalho.

No estado do Rio de Janeiro, reduto onde se encontra a unidade de nossa pesquisa, três anos após a regulamentação da Lei Orgânica da Saúde (Lei no 8.080 de 1990), o então ministro da Saúde Jamil Haddad decreta "calamidade pública". Esse fato, segundo Vasconcelos (2012), teria se dado em meio ao processo de enxugamento do Estado, iniciado no governo Collor de Mello (19901992) e radicalizados nos mandatos do governo Cardoso (1995-2002).

Costa (2008) faz ainda uma crítica a não inserção de algumas mudanças que foram propostas pela reforma sanitária, o que não teria gerado um avanço no sentido de efetivamente superar o modelo médico-hegemônico, uma vez que, o sistema de saúde deveria centrar suas ações nas reais necessidades de saúde da população e articular ações intersetoriais com as demais políticas sociais que intervêm nas condições de vida da população, como é o caso da habitação, do saneamento, das condições de trabalho, da educação, Assistência Social, previdência social, acesso à terra, etc.

Martini et al (2013), por sua vez, mostram que, após a assinatura do Pacto de Saúde em $2007^{10}$, a Secretaria Municipal de Saúde do Rio de Janeiro começa a assumir níveis de atenção de média complexidade e a presença de assistentes sociais na saúde municipal passa a se tornar mais expressiva. Em 2008, com a criação das Unidades de Pronto Atendimento (UPAs) e com a regulamentação do Núcleo de Apoio à Saúde da Família (NASF), a Secretaria Municipal de Saúde contrata assistentes sociais para atuar nesses espaços, ampliando o número de profissionais inseridos na saúde do município.

Dentre as demandas de trabalho que se colocam para os assistentes sociais na área da Saúde, Costa (2008) apresenta as seguintes ações:

1) Levantamento de dados - caracterização e identificação das condições socioeconômicas, familiares e sanitárias dosusuários;

\footnotetext{
10 Segundo o Conselho Nacional de Saúde, o "Pacto pela Saúde" é um conjunto de reformas institucionais do SUS pactuado entre as três esferas de gestão (União, Estados e Municípios), com o objetivo de promover inovações nos processos e instrumentos de gestão, visando alcançar maior eficiência e qualidade das respostas do Sistema Único de Saúde. Ao mesmo tempo, o Pacto pela Saúde redefine as responsabilidades de cada gestor em função das necessidades de saúde da população e na busca da equidadesocial.
} 
2) Interpretação de normas e rotinas - procedimentos de natureza educativa, como orientações, aconselhamentos e encaminhamentos individuais ecoletivos;

3) Agenciamento de medidas e iniciativas de caráter emergencialassistencial - constituem emergências sociais que interferem no processo saúdedoença, bem como relacionam-se à demanda reprimida/déficit de oferta dos serviços de saúde e demais políticas sociais públicas e, sobretudo, relacionamse às desigualdades econômicas, políticas e sociais e culturais a que estão submetidos a maioria da população usuária do SUS. Nesses termos, são atividades voltadas para agilização de internamentos/leitos, exames e consultas (extras), tudo que envolve o tratamento e acompanhamento dos usuários e sua família ou cuidadores, tais como o acesso a transporte, medicamentos, órteses, próteses, sangue, alimentos, roupa, abrigo adequado, traslado, atestados/declarações, etc. Demandam a mobilização e articulação de recursos assistenciais inerentes à política de saúde e as demais políticas sociais, portanto dentro e fora do sistema desaúde;

4) Procedimentos de natureza socioeducativa, informação e comunicação em saúde: ação transversal aos demais núcleos de objetivação que consiste em: a) assegurar aos usuários as informações em relação às normas institucionais, aos serviços oferecidos, direitos, aos trâmites burocráticos, acesso ao prontuário, informações sobre os procedimentos realizados, terapêuticas administradas, etc.; b) ampliar a democracia institucional e a capacidade de análise e de intervenção dos sujeitos e dos grupos, e por meio da construção e dinamização de espaços coletivos em que se analisa e delibera sobre questões relativas à gestão e à prestação dos serviços. Exemplos: instalação e funcionamento de ouvidorias, conselhos gestores de unidades, rodas de conversa,etc;

5) Desenvolvimento de atividades de apoio pedagógico e técnicopolítico - consistem em articulação e/ou realização de atividades junto aos funcionários, aos representantes dos usuários no sistema, aos grupos organizados, lideranças comunitárias e à comunidades em geral, que envolvem desde a realização de reuniões, oficinas de trabalho, cursos, seminários voltados para discussão de temas afetos ao processo de construção e consolidação permanente do SUS, interesse da área da saúde pública, à assessoria para elaboração de relatório, documentos reivindicatórios como abaixo assinado, apoio à organização de processos eleitorais,etc.

$\mathrm{Na}$ pesquisa de Vasconcelos (2012), apareceram outras demandas 
comuns ao plantão de qualquer unidade de Saúde que, embora algumas não sejam atribuições privativas do Serviço Social, destacamos: Ficha social, visita domiciliar, conhecimentos dos recursos da unidade, entre outros.

Costa (2008) afirma que o assistente social se insere, no interior do processo de trabalho em saúde, como agente de interação ou como um elo orgânico entre os diversos níveis do SUS e entre este e as demais políticas sociais setoriais, o que nos leva a concluir que o seu principal produto parece ser assegurar - pelos caminhos mais tortuosos - a integralidade das ações.

A prática do assistente social deve estar pautada nas três dimensões da profissão: teórico-metodológica, ético-política e técnico-operativa. Vasconcelos (2006) destaca como pressupostos ideopolíticos, o comprometimento com a garantia dos direitos civis, sociais e políticos dos segmentos populares; com a preocupação de análise dos serviços, tendo em vista os direitos sociais, especialmente o direito à saúde, com vistas a contribuir para qualidade do espaço público, para o controle social e, em última instância, para a construção de uma nova ordemsocial.

A pesquisa da autora supracitada demonstrou que a prática da maioria dos assistentes sociais não se remete ao projeto hegemônico, mas está hipotecada aos condicionantes político-institucionais que limitam suas escolhas.

O que está em jogo para os assistentes sociais que objetivam uma ação profissional que rompa com o conservadorismo preponderante no domínio da prática é, partindo da definição clara e consciente de suas referências éticopolíticas, a apropriação de uma perspectiva teórico-metodológica que, colocando referências concretas para a ação profissional, segundo a autora, possibilite a reconstrução permanente do movimento da realidade - objeto da ação profissional, enquanto expressão da totalidade social, gerando condições para um exercício profissional consciente, crítico, criativo e politizante, que só pode ser empreendido na relação entre teoria e prática.

Já na pesquisa de Vasconcelos (2012) chama-se atenção às demandas para o Serviço Social que foram apontadas pelos assistentes sociais entrevistados que, em geral, se restringem a ações burocráticas que seguem mecanicamente normas impostas pelo regulamento da administração, autoridade ou de seu representante. Os procedimentos e instrumentos levantados na pesquisa supracitada se referem a entrevistas e reuniões.

Vasconcelos (2012) revela que, ainda hoje, a organização do Serviço Social continua [subordinada à assistência médica individual ao caráter da doença] e que há uma necessidade de uma aproximação com a saúde pública, 
já que a promoção e a proteção da saúde individual e coletiva, mesmo colocadas como prioridade na legislação, começam a ser desvalorizadas e, consequentemente, recusadas pela política de saúde.

A Promoção da Saúde ${ }^{11}$, com vistas a tratar a questão da saúde para além do processo saúde-doença, pode ser uma estratégia para buscamos visibilidade em nossas ações profissionais, por isso, é importante contextualizá-la.

A Política Nacional de Promoção da Saúde tem como objetivo promover a equidade e a melhoria das condições e dos modos de viver, ampliando a potencialidade da saúde individual e coletiva e reduzindo vulnerabilidades e riscos à saúde decorrentes dos determinantes sociais, econômicos, políticos, culturais e ambientais (Brasil, 2014).

A Promoção da Saúde, fundamentando-se nas Cartas das Conferências Internacionais, é um conjunto de estratégias e formas de produzir saúde, no âmbito individual e coletivo, que se caracteriza pela articulação e cooperação intra e intersetorial e pela formação da Rede de Atenção à Saúde, buscando se articular com as demais redes de proteção social, com ampla participação e controlesocial.

Para Sícoli e Nascimento (Apud Quintino et al, 2012), a promoção de saúde pressupõe uma concepção que não restrinja a saúde à ausência de doença, mas que sejacapaz de atuar sobre seus determinantes. Incidindo sobre as condições de vida da população, extrapola a prestação de serviços clínicoassistenciais, supondo ações intersetoriais que envolvam a educação, o saneamento básico, a habitação, a renda, o trabalho, a alimentação, o meio ambiente, o acesso a bens e serviços essenciais, o lazer, entre outros determinantes sociais da saúde.

Quintino et al (2012) entendem que a incorporação do amplo leque de ações do serviço social na prática junto à Estratégia da Saúde da Família e a outros níveis de atenção, valendo-se da Promoção da Saúde, cria enormes possibilidades no sentido de buscar uma maior resolutividade, um olhar integral sobre os diferentes contextos e dimensões socioculturais e biopsicossociais, o que certamente induz ao desenvolvimento de ações intersetoriais, aliando mobilização social, equidade, justiça social e defesa pública da saúde.

Dessa forma, neste estudo estamos buscando essa aproximação do Serviço Social com a promoção da saúde como alternativa de desenvolver novas formas de ação dessa categoria profissional, especificamente junto às demandas

11 Regulamentada pela Política Nacional de Promoção a Saúde de 2006, com última atualização em 2014. 
para viabilização de alta hospitalar, de forma que possamos contribuir para práticas que compreendam a saúde em seu sentido ampliado, superando o modelo biomédico que insiste em imperar na política de Saúde.

Por isso, estamos considerando a intersetorialidade como papel importante na promoção da saúde em meio ao processo de alta hospitalar. Entretanto, vale lembrar que França e Cavalcante (2013) chamam atenção em relação ao debate sobre a intersetorialidade, que deverá contemplar a dinâmica da sociedade considerando sua dialética e sua história, não pode estar restrita a procedimentos administrativos, visto que a macropolítica e a economia rebatem decisivamente no planejamento e implementação das políticas sejam elas, sociais, territoriais ou econômicas.

\section{2. \\ Notas sobre intersetorialidade: alternativas para a prática profissional do/a assistente social}

Nesse tópico vamos trabalhar o conceito da intersetorialidade como uma das estratégias para atuação dos profissionais em suas práticas, em especial, as do Serviço Social no momento de viabilização de alta hospitalar de um usuário.

Pereira (2014) procura explicar a intersetorialidade a partir da interdisciplinaridade, já que essa é uma discussão mais antiga e com maior arcabouço bibliográfico. Assim, segundo a pesquisadora, os dois conceitos estimulam o abandono de categorias edesetores, causado pelo aumento exagerado de especializações, culminando em mera soma das partes, e estimulam para que as partes se interliguem, superando a fragmentação.

Neste trabalho, como já sinalizado, a intersetorialidade é vista como uma das estratégias possíveis para intervenção na "alta social", em hospitais de atenção terciária.

Durante a análise dos instrumentos utilizados pelos assistentes sociais do Hospital Municipal Miguel Couto, em que se concentra nosso campo de pesquisa, observamos que no processo de trabalho referente à intervenção desses profissionais nas altas hospitalares, na maioria das situações relatadas, buscou-se uma articulação com outras políticas sociais na tentativa de obter sucesso no casotrabalhado.

Por isso, faz-se necessário, aqui, que compreendamos um pouco do que se trata esse fenômeno da integração entre setores para solucionar demandas, aparentemente, internas da Política de Saúde. Assim, neste capítulo, buscaremos compreender como a intersetorialidade pode contribuir com a 
prática profissional do assistente social nas intervenções junto às "altas sociais". Importante frisar que intersetorialidade é mais que a articulação entre setores.

A intersetorialidade é sempre um grande desafio a ser trabalhado no campo da Promoção da Saúde, por exemplo. Silva (2014) revela que a escassez de estudos em profundidade sobre ações intersetoriais existentes é apontada como desafio para o crescimento e aprimoramento da intersetorialidade.

Andrade (2006, Apud Mioto e Schütz, 2011) se reporta a Medicina Social, no século XIX, na Europa, passando pelo Movimento Internacional de Promoção da Saúde, no século XX, para explicitar como a preocupação com a saúde culminou no conceito de intersetorialidade, enquanto estratégia de promoção da saúde.

Gostaríamos de trazer três notas a respeito da intersetorialidade, que podem ajudar na construção desse trabalho e situar os leitores sobre qual perspectiva conceitual estamos olhando quando abordamos esse assunto.

Começaremos, pois, a primeira nota, com a análise que consideramos crucial para essa discussão: os setores. Se procurarmos a definição de setor em dicionários tradicionais da língua portuguesa, observaremos que ele está definido como um ramo. Isso significa que quando setorizamos determinados elementos, estamos colocando-os em nichos catalogados, isto é, separados, divididos, cada um segundo seu grau de importância, de estratégia. Por exemplo, no supermercado, o setor das carnes está separado do setor dos legumes, pois eles têm especificações diferentes de armazenamento e de disposição em prateleiras e isso parece facilitar a busca de quem for comprá-los. Isso notoriamente acontece devido aos avanços de estudos desenvolvidos por setores profissionais que lidam com esse tipo de material desde que o mundo começou a comercializar os alimentos.

Fazendo uma analogia com as Políticas Sociais/Públicas, percebemos que elas também parecem estar catalogadas, divididas, separadas, setorizadas: Política de Saúde, Política de Assistência Social, Política de Educação, etc.

Konno et al (2017) alertam que é preciso considerar que o Estado brasileiro tem sua estrutura administrativa organizada de acordo com a lógica setorial, segundo a especialização do conhecimento, da divisão de competência e de funções.

As autoras consideram ainda que essa organização da administração pública cria um procedimento burocrático, o que tem contribuído para atuação isolada das diferentes políticas sociais.

Dessa forma, cada setor tende a ter suas próprias responsabilidades e 
competências. Isso, a princípio, parece criar um atendimento especializado, mas pode gerar um atendimento limitado. Criar "muros" nas instituições, nas políticas e também nas categorias profissionais em nome de um conhecimento que parece estar mais aprofundado sobre determinado assunto é, na verdade, fechar a oportunidade para soma de novos saberes.

Pereira (2014) entende que se convencionou achar que as políticas sociais são divididas em "setores" particulares, mas essa categoria, nesse caso, seria insólita, já que cada política teria elementos dos demais, o que dificultaria a sua programação e financiamentos isolados.

Apesar da administração pública setorializar as políticas públicas de acordo com seus ministérios, autarquias, secretarias, etc., também como uma forma de organização (do aparato estatal), isso pode acabar criando especializações estrategicamente formadas para aumentar a burocracia e dificultar o acesso dos usuários às políticassociais.

Essa burocratização pode ocorrer de um "setor" para o outro ou até dentro do mesmo "setor". Isso burocratiza não só as políticas públicas, mas também o atendimento dos profissionais. Dificultando o acesso por meio da burocracia, diminui-se a quantidade de pessoas atendidas e, com isso, diminui a verba que deveria ser destinada à área social. Desta forma, a burocracia pública legitima a dominação de classe. Como ressaltam Souza Filho e Gurgel (2016):

[...] a burocracia, enquanto expressão da ordem capitalista, é essencialmente uma ordem administrativa voltada para dominação da classe burguesa para viabilizar sua finalidade de produção e apropriação privada da mais valia, realizada pela exploração da força de trabalho (Souza Filho e Gurgel, 2016, p. 124).

Konno et al (2017) ressaltam que a fragmentação das políticas setoriais cria dificuldades para compreensão de que as expressões das desigualdades sociais não estão desvinculadas das causas estruturais.

Entretanto, "setorializar" as políticas sociais públicas pode ser uma forma de organização das instituições, de planejamento, de gestão, mas é preciso estar atento às contradições existentes em meio a essa categorização. É preciso superar a burocracia, a financeirização desleal, a fragmentação, a focalização e a privatização das políticas sociais.

Seguimos esse debate, pois, com a segunda nota, que diz respeito ao prefixo "inter". Essa palavra, segundo o dicionário Aurélio, transmite a noção de relação recíproca. Nas políticas sociais, pode-se dizer que ela está relacionada à ideia de troca de conhecimento. 
Pereira (2014) chama atenção sobre o prefixo "inter" no sentido de que esse não se limite ao conceito de entre "setores", mas que seja supra e, de fato, supere o estigma de catalogalização. Assim, esse termo não remete a uma relação isolada entre as partes - os setores -, mas ganha uma dimensão dialética: a de ser unitária ou total.

A autora supracitada entende que esse termo, ligado à noção de setor (intersetorialidade) e de disciplina (interdisciplinaridade), remete à uma relação dialética, isto é, ele possui características que devem ser consideradas, como a reciprocidade e a contradição.

A reciprocidade produz e reproduz ações cooperativas entre as partes. No caso das Políticas Públicas, isso envolve a troca de saberes e de experiências entre profissionais e a troca de atividades e de serviços ofertados entre os "setores" e/ou entre as Políticas Sociais. O que tornará uma relação dialética é a contradição entre as partes,éseu movimento de transformação.

Desta forma, considerando que a intersetorialidade é também uma relação dialética (Pereira,2014) e deve estar sempre em desenvolvimento em busca de inovação, ela não está aqui sendo considerada como uma relação entre "setores" que possui uma "fórmula mágica" e garanta, por si só, a integralidade no atendimento do indivíduo. Entendemos que a integralidade que as legislações propõem não pode ser garantida somente com a oferta de serviços sociais e tampouco com a intersetorialidade.

Por isso, nesta pesquisa estamos considerando a intersetorialidade como caminho possível e também necessário para concretização da integralidade, mas nãoúnico.

Conforme Bellini e Faler (2014), a política de saúde, regulamentada pela Lei Brasileira no 8.080 de 1990 (Brasil, 1990), concebe a intersetorialidade como a articulação entre diferentes setores para a materialização da promoção, prevenção e recuperação da saúde. Está ancorada na concepção ampliada de saúde e tem a função de responsabilizar todos os gestores na construção de agenda em todos os níveis de atenção das políticas sociais.

No caso brasileiro, com o advento do neoliberalismo do final da década de 1980 e início da década de 1990, chegou ao país um ideal político de "reforma" do Estado. Um projeto internacional, mas personalizado para o nosso país periférico. Aqui, deveria se firmar as iniciativas privadas, a redução ainda mais drástica do Estado interventor, a administraçãogerencial, a mercadorização das políticas sociais, a redução de direitos, a desvalorização do público e a exaltação do privado. Todo esse pacote gerou consequências drásticas para a classe 
trabalhadora brasileira.

As mudanças trazidas com esse contexto para as Políticas Sociais Públicas, como já explicitadas, não garantem a qualidade do atendimento aos usuários. Assim, é possível questionar: como a intersetorialidade entre políticas tão sucateadas com a falta de investimento público poderia garantir a integralidade do atendimento?

Iniciamos agora a terceira nota que gostaríamos de pontuar para dar início ao debate aqui proposto: a intersetorialidade.

Para tratar desse conceito, buscaremos entender se a gestão pode influenciar diretamente na eficácia e na eficiência da intersetorialidade e de que modo isso ocorre (se ocorre). A destinação do fundo, os interesses, o gerenciamento das políticas, a superação da concepção de setores, enfim, o cunho político da gestão, de fato, muda os rumos da intersetorialidade. Entendemos que o referido conceito é organizado e definido na gestão e, ocorre, sobretudo, a partir da gerência, mas consolida-se na ponta do processo, na qual (onde) o atendimento com o usuário éconcretizado.

Sustentamos que a compreensão e a intervenção na realidade não garantem a melhoria das condições de vida da classe trabalhadora, mas contribuem para que, ainda que pontualmente, modifiquem minimamente a qualidade de vida dos sujeitos que atendemos enquanto assistentes sociais, até que possamos unir forças para superação da exploração de uma classe sobre aoutra.

Em sua análise sobre a intersetorialidade, Costa (2010) revela que

(...) embora o Ministério da Saúde resuma a questão das desigualdades em saúde a uma desigualdade de oferta de bens e serviços reduzida à desarticulação intersetorial, ainda muito distante da compreensão firmada na própria Lei 8080/90, a qual ressalta que os níveis de saúde da população expressam a organização social e econômica do país. Seu mérito consiste na possibilidade de uma reorientação da política de saúde no sentido de desencadear esforços para a construção de medidas e ações pautadas em uma concepção ampliada de saúde, da qual deriva a necessidade de articulação intersetorial entre a saúde e as demais políticas públicas (Costa, 2010, p. 17).

A partir do exposto, a autora supracitada entende que, mesmo um alto grau de eficiência na execução das políticas sociais moldadas pela intersetorialidade, não é suficiente para superação das desigualdades sociais, uma vez que ela tem suas raízes na produção da riqueza, cada vez mais coletiva, e na sua apropriação, cada vez mais privada, mas (que) é possível reduzi-las. E acrescenta, 
(...) mais que mudar concepções, valores e práticas, a construção da intersetorialidade exige mudanças na estrutura e na cultura organizacional que, em última instância, se relaciona coma correlação de forças entre as classes sociais na defesa dos projetos em disputa. Por isso a luta pela sua construção, em uma realidade de profundas desigualdades como a brasileira, traz consigo um potencial de questionamento ao modelo médico hegemônico e ao Projeto Privatista (Costa, 2010, p. 133).

A apreensão da realidade é complexa mesmo quando buscamos olhar todos os lados a partir da identificação das expressões da "questão social". Porém, quando das Políticas Públicas em sua forma setorial não busca a integração entre elas, essa complexidade aumenta. Konno et al (2017) ressaltam:

Parte-se do pressuposto de que a fragmentação promovida pelo isolamento das políticas sociais cria dificuldades para a compreensão de que as expressões das desigualdades sociais não estão desvinculadas das causas estruturais que as produzem. Tomar essas expressões como objetos particularizados de cada uma das Políticas Sociais obscurece a noção de totalidade (Konno et al, 2017, p.120121).

A intersetorialidade não é um mero instrumento da equipe técnica. Apesar da participação dos profissionais para que ela possa se materializar nas instituições da ponta, os autores supracitados entendem que ela não depende somente da "boa vontade" dos trabalhadores (Konno et al, 2017, p.124).

Portanto, a intersetorialidade pressupõe ações coletivas e organizadas, estrategicamente pensadas pela gestão e continuamente provocadas pela equipe técnica. Bellini e Faler (2014) compreendem que a intersetorialidade sobressai desde uma visão instrumental, que, na maioria das vezes, traduz-se em encaminhamentos e em um movimento de repasse, sem diálogo, até a sua configuração como um trabalho que, ao envolver vários campos do saber ou setores dos serviços públicos, se propõe a criar novos conhecimentos, na perspectiva de compreender o fenômeno na sua totalidade e a ele responder adequadamente.

Para a Política Nacional de Promoção da Saúde, a intersetorialidade refere-se ao processo de articulação de saberes, potencialidades e experiências de sujeitos, grupos e setores na construção de intervenções compartilhadas, estabelecendo vínculos, corresponsabilidade e cogestão para objetivos comuns.

$\mathrm{Na}$ administração, ela deve ser gerida no sentido de superar a setorialização e a focalização das Políticas Sociais; já na ponta, deve ser provocada pelo compartilhamento de saberes e de experiências, inclusive, de 
articulação entre as redes do território. Neste sentido, de acordo com Silva, K. L. et al (2014), a intersetorialidade é entendida como uma estratégia para resolver problemas que extrapolam o âmbito de atuação setorial e é referida como uma política proposta para orientar e organizar a promoção da saúde nos municípios cenários.

Para Silva e Tavares (2016), fica evidente o desafio da implementação da intersetorialidade associada a um trabalho em equipe com corresponsabilidade entre a saúde e os outros setores, possibilitando troca de saberes, planejamento de ações e tomada de decisões de forma compartilhada. Assim, a intersetorialidade incorpora a ideia de integração, de território, de equidade, de direitos sociais e outros. Esse novo fazer demanda mudanças de valores da cultura para um agircoletivo.

Como vimos, compõe a intersetorialidade a dimensão política da gestão, isto é, ela atende interesses antagônicos, pode ser utilizada na perspectiva da democracia dos direitos sociais - que embora ela seja uma contribuição reformista e não transformadora, ela faz parte dos ganhos da classe trabalhadora a partir de suas lutas por melhores condições -, mas também pode seguir na direção do Estado Mínimo, quando é utilizada como resposta paliativa para as demandas dos trabalhadores em meio a cortes na áreasocial.

Desse modo, concordamos com Bellini e Faler (2014) ao afirmarem que a concepção de intersetorialidade deve contemplar, então, a construção de interfaces e diálogos entre setores e instituições governamentais e não governamentais, as quais, em suas intenções/ações, devem visar ao enfrentamento de problemas sociais complexos e que superam a capacidade das políticas públicas enfrentarem de forma solitária.

Assim, a intersetorialidade também visa contribuir para a afirmação de que uma política social isolada não responde, na totalidade, pelo conjunto de demandas que Ihes são atribuídas setorialmente, se considerada a perspectiva de um atendimento integral aos seus demandatários. Azevedo et al (2012, p.1333), revelam que:

A intersetorialidade tem o potencial de revitalizar tais políticas, estimulando ações promotoras da saúde que contemplem os complexos condicionantes do processo saúde-doença. Entretanto, evidenciam-se alguns problemas para atingir esse desafio. Destacam-se o despreparo político e técnico de gestores e profissionais da saúde para assumir ações intersetoriais e questões de ordem administrativa que dificultam a execução integrada de ações. Tal despreparo leva, entre outros danos, à falta de reconhecimento de alguns dos temas das políticas como questões legítimas de Saúde Coletiva. Além disso, permanecem em muitas das agendas das políticas, decisões centralizadas que impedem a participação da 
comunidade e o surgimento de problemas ajustados às realidades locais, cujas soluções exigem intervenções intersetoriais e criativas. Assim, torna-se essencial fomentar um efetivo processo educativo interdisciplinar que forme profissionais da saúde com visão intersetorial em sintonia com as diretrizes das políticas públicas de promoção da saúde. Também é importante valorizar a dimensão territorial e as redes sociais, potencializando processos participativos que ampliem a perspectiva intersetorial dessas políticas, bem como estimular a ativação do sujeito nos processos decisórios (Azevedo et al, 2012, p.1333).

Embora tenhamos a intersetorialidade como premissa da Saúde Pública, ela ainda é um desafio a ser enfrentado em meio à setorialização das instituições políticas que criam entraves para a viabilização da troca de saberes e experiências entre setores, negando, assim, a integralidade do sujeito.

Para Junqueira (2000), a intersetorialidade incorpora a ideia de integração, de território, de equidade, enfim, dos direitos sociais. É uma nova maneira de abordar os problemas sociais. Cada política social encaminha a seu modo uma solução, sem considerar o cidadão na sua totalidade nem a ação das outras políticas sociais, que também estão buscando a melhoria da qualidade devida.

Desse modo, a intersetorialidade busca quebrar visões fragmentadas e olhar o sujeito em sua integralidade. Ela está longe de estar resumida a meras reuniões ou encaminhamentos. Mas deve estar pautada na integração das políticas sociais com foco nos DeterminantesSociais.

Essa busca por aproximação com outros setores, apareceu fortemente nas fichas sociais que analisamos em uma clara tentativa de buscar estratégias para solução dos casos apresentados que a Saúde, por si só, não seria capaz de abarcar. É o que Junqueira (2000) chamou de transcender um único setor social na busca pela articulação de saberes e experiências.

Segundo o mesmo autor, a intersetorialidade deve constituir uma concepção que deve informar uma nova maneira de planejar, executar e controlar a prestação de serviços, para garantir um acesso igual aos desiguais. Isso significa alterar toda forma de articulação dos diversos segmentos da organização governamental e de seus interesses.

Para promoção desse olhar integral à saúde dos sujeitos, é preciso um planejamento articulado de ações e serviços. Isso irá envolver todos os atores sociais possíveis: gestão, trabalhador técnico e usuários. A prática intersetorial vislumbra uma outra abordagem, conforme explica Junqueira (2000) na exposição a seguir. 
(...) a prática intersetorial que privilegia a negociação pode alcançar uma dimensão transetorial, pois cria um novo olhar e instaura novos valores, mediante o respeito das diferenças e a incorporação das contribuições de cada política social no entendimento e na superação dos problemas sociais (Junqueira, 2000, p. 43).

Para a intervenção dos assistentes sociais do hospital em que realizamos nossa pesquisa no que diz respeito à alta hospitalar, observamos que os assistentes sociais, na maioria dos casos relatados, procuraram fortalecer o contato com as redes, sejam elas comunitárias ou intersetoriais e, em algumas vezes, até mesmo intrasetorial ${ }^{12}$. Esse marco vislumbra que os profissionais do Serviço Social compreendem que a solução paraproblemas complexos não pode estar situada em um único setor. Por isso, buscam alcançar apoio externo no sentido de viabilizar direitos sociais.

A pesquisa de Mioto e Schütz (2011) mostrou que os assistentes sociais acreditam que as ações intersetoriais se reduzem ao encaminhamento e ao repasse de informações, no âmbito dos serviços.

As autoras observaram, entretanto, que essa dificuldade dos assistentes sociais de pensar ou reconhecer a intersetorialidade em suas ações profissionais reflete a própria fragmentação da rede de serviços e da gestão das políticas sociais. Uma possível explicação, também, é que os assistentes sociais ao trabalharem cotidianamente com a intersetorialidade, a transformam em tarefa rotineira,naturalizando-a.

Entender que o encaminhamento é intersetorial quando o profissional entra em contato com outra instituição para captar informações desta, e melhorar o atendimento ao usuário é reduzir a integralidade do cuidado que está por trás da intersetorialidade no que tange à Promoção da Saúde.

A pesquisa mencionada acima também mostrou que na construção de relações profissionais pautadas pela intersetorialidade, a equipe multiprofissional demanda que o assistente social esteja preparado para se inserir em equipes multiprofissionais e interdisciplinares.

E, apesar de apontar que, após esse exercício, o trabalho do assistente social é invisibilizado, compreendemos que aí pode se encontrar um ponto importante para que possam resistir à correlação de forças dentro da instituição. É nesse momento também que o papel do Serviço Social ganha destaque dentro de uma política velada por uma hierarquia mistificada.

\footnotetext{
${ }^{12} \mathrm{Na}$ Política Nacional de Promoção da Saúde, além da articulação e sintonia entre as estratégias de produção da saúde dentro do setor saúde, busca-se também a ampliação da escuta dos trabalhadores e serviços de saúde na relação com os usuários, considerando suas necessidades e condições de vida, o que foi definido como ação intrasetorial.
} 
Consideramos, pois, que encaminhamentos, ligações, pareceres, entre outros instrumentos, são importantes para o exercício profissional e se configuram como parte de uma ação intersetorial a nível prático. Porém, se as ações intersetoriais ficam a encargo dos profissionais, os serviços não têm condições de promover ações intersetoriais sistemáticas.

Mioto e Schütz (2011) revelam que, para os assistentes sociais, o maior desafio na concretização da intersetorialidade está no plano da gestão, porque o profissional sabe que a intersetorialidade tem que existir, mas se vê limitado para promovê-la. Frisam que construir a rede integrada não é atribuição dos profissionais que atendem os usuários, mas dagestão.

Azevedo, et al (2012, revelam que

(...) a intersetorialidade na saúde propõe um diálogo e ações complementares entre setores diversos, sem desconsiderar a necessidade de integrar ações dentro de cada setor. Ou seja, pode-se dizer que ao buscar a intersetorialidade, esperase encontrar ações conjuntas que perseguem o mesmo objetivo entre setores diferentes; entre o público e o privado e entre a sociedade civil e o Estado em instâncias nas quais essas dicotomias ainda persistem (Azevedo et al, 2012, p. 1336).

Na nossa pesquisa, realizada no Hospital Municipal Miguel Couto, no município do Rio de Janeiro, para viabilização da alta hospitalar - que é o foco deste estudo - e, assim se tratando, de "alta social", os relatos profissionais mostraram articulação com outras políticas em quase todos os atendimentos, conforme veremos mais adiante. Porém, quase não houve relato de retorno ou continuidade de articulação entre a política de saúde e as demais. Muitas vezes, a demora da resposta dos outros setores ao caso acabou por deixar os usuários sem a integralidade do atendimento que culminava em recorrentesevasões.

Em contrapartida, a pesquisa mostrou que há pouca articulação entre o Serviço Social e os demais profissionais, concentrando essas pequenas ações em curtas conversas para solicitação de atendimento ou de documentação específica, como pareceres médicos. Esses dados corroboram com outras pesquisas apresentadas anteriormente que a precarização das políticas públicas é um fator dificultoso para a articulação da intersetorialidade. De todo modo, o número expressivo apresentado na presente pesquisa sobre tentativas de operabilidade junto a outras políticas, sugere que a intersetorialidade ainda é a tentativa primordial de busca pela integralidade do atendimento quando a política de saúde não consegue dar conta por si.

As principais articulações que apareceram foram com o setor de identificação civil - Detran - e Delegacia de Descoberta de Paradeiros - DDPA - 
(em caso de entrada de pessoas não identificadas); seguido da justiça (defensoria, conselho tutelar, promotoria do idoso, entre outros) e; Assistência Social (Centros de Referência da Assistência Social [CRAS], Centros de Referência Especializados de Assistência Social [CREAS]); Secretaria Municipal de Assistência social, entre outros); e, em seguida, outras unidades de saúde, como de especialidade psiquiátrica, baixa complexidade (Estratégia Saúde da família).

Apesar de defendermos, aqui, a importância dos diálogos e instrumentos na busca pela intersetorialidade visando à Promoção da Saúde, ratificamos que as pesquisas têm mostrado que a gestão destas políticas ainda não criou canais capazes de consolidá-la. Ao contrário, as políticas sociais estão fragmentadas e focalizadas.

A pesquisa de Mioto e Schütz (2011) revelou que os assistentes sociais denotam que as dificuldades que se colocam na construção da intersetorialidade estão arraigadas ao campo da cultura nacional voltadas ao patrimonialismo, a cultura do favor, a personalização das relações profissionais, entre outras.

Muitos são os desafios para a viabilização da intersetorialidade conforme sugere a Promoção da Saúde. A fragmentação das políticas sociais e sua não efetivação por parte da administração pública são fatores importantes que limitam as práticas profissionais na ponta, por mais que se busquem a todo custo promovê-la, por meio de encaminhamentos, interlocuções, documentos, reuniões e outros. A intersetorialidade, portanto, apresentamuitos desafios na sua implantação e desenvolvimento que precisam ser superados. Dentre eles, destacam-se:

- Maior financiamento em políticaspúblicas;

- Conjuntura favorável à efetivação de sistemas universais de seguridade social, com criação de medidas capazes de superar os grandes entraves de ordem estrutural;

- Superação da cultura institucional enraizada em práticas centralizadoras e verticalizadas;

- Transformação das políticas e culturas institucionais e da sociedade, tendo em vista a defesa da saúde coletiva enquanto resultante da qualidade devida;

- Rompimento com práticas moldadas pela fragmentação, especialização, setorialização, e avançar na perspectiva de compartilhar saberes, tarefas e atividades no campo daintersetorialidade. 
Esperar uma integração entre as políticas sociais em busca da viabilização dos direitos sociais faz da intersetorialidade uma proposta ousada que demanda lutas e vontade política.

Nesta pesquisa, a intersetorialidade se apresenta como temática correlata ao processo de "alta social". Por isso, é preciso esclarecer que autores que discutem a temática da intersetorialidade mostram que esse estudo é considerado relativamente novo. As pesquisas nessa área ganharam fomento há cerca de vinte anos, por isso, é um tema complexo e desafiador. A intersetorialidade ainda se apresenta na fase de estruturação de conceitos e, segundo Pereira (2014), ainda não tem um sentido epistemológico totalmente definido. A intersetorialidade é sempre um grande desafio a ser trabalhado no campo da Promoção da Saúde. Silva (2014) revela que a escassez de estudos em profundidade sobre ações intersetoriais existentes é apontada como desafio para o crescimento e aprimoramento daintersetorialidade.

Ao analisar a intersetorialidade, partimos do entendimento de Couto et al (2010) que destacam ser esta uma articulação entre políticas sociais, que desenvolve ações conjuntas destinadas à proteção social e enfrentamento das desigualdades. É a integração de programas e serviços visando à superação da fragmentação da atenção às necessidades sociais da classe trabalhadora. É a compreensão de que a intersetorialidade também supõe as vontades dos agentes públicos promovendo-a e respeitando a diversidade e as particularidades de cada setor.

Portanto, compreendendo a saúde como conceito multilateral, associada a diversos determinantes sociais, como já sinalizado, e entendendo casos sociais como situações em que o paciente não tem residência e/ou família, casos que envolvem o Conselho Tutelar, ou que envolvem a alta para a mãe e não para o bebê, como exemplifica Vasconcelos (2012) eque culminam em impossibilidade para "alta social", buscaremos compreender a atuação do assistente social nesses casos e a implicação da intersetorialidade frente essa demanda.

Pereira (2014) trata a intersetorialidade não como um conceito, mas como um neologismo em que se atribui um novo sentido. Logo, esclarecemos, desde já, que não buscamos trazer definições para essa terminologia, mas suas contribuições frente às demandas de intervenção do assistente social em situações de "alta social".

Sem pretensões de esgotar o debate acerca da intersetorialidade, a tratamos a partir do entendimento de um processo que envolve todos os setores, muito além de especialistas ou de políticas com especificidades. 
Queremos entender se, na perspectiva da "alta social" ela se comporta como unificação de setores ou se está limitada a encontros, debates superficiais, encaminhamentos e outros contatos que não chegam a mostrar a visão transcendental que os mais recentes sentidos propostos nas bibliografias do pensamento crítico para a intersetorialidade se propõem.

Alguns autores colocam a intersetorialidade no campo da gestão, outros da prática e há ainda aqueles que elaboram duras críticas sobre o caminho que vem sendo desenhado a partir dela nas políticas sociais. Lotta (2016) aponta da seguintemaneira:

\begin{abstract}
Analisando a experiência brasileira, vemos diferentes graus de materialização da intersetorialidade. Algumas experiências buscam materializá-la no processo de formulação das políticas públicas, considerando a integração de temas no planejamento; outras materializam-se em uma ação coordenada no processo de implementação; e há outras que realizam intersetorialidade apenas no processo de monitoramento conjunto de diferentes ações relacionadas a um mesmo tema, território ou população (Lotta, 2016, p. 54).
\end{abstract}

Assim, para fins deste estudo, adotamos a intersetorialidade como um elemento estratégico para intervenção profissional do assistente social na "alta social", mas não o único.

A seguir, veremos como tem se dada as estratégias profissionais de atuação dos assistentes sociais do Hospital Municipal Miguel Couto - HMMC em casos que demandem "alta social". Além disso, veremos também como os o Serviço Social desta unidade tem trabalhado com a intersetorialidade e o que se pode esperar disso. 
4

\section{"Alta Social": dilemas, desafios e possibilidades - a realidade da emergência do Hospital Municipal Miguel Couto}

4.1.

\section{Trajetória acadêmica e pesquisa de campo}

Já na segunda fase do meu estudo, a pesquisa de campo, me debrucei com alguns novos desafios: a autorização para pesquisa e a compreensão sobre a análise documental, metodologia que opteiutilizar.

Devido à aproximação do Hospital Municipal Miguel Couto com a PUC-Rio e conhecimento com profissionais que ali trabalham, decidi por trazê-lo como instituição de estudo de minha pesquisa decampo.

Os dados que seriam utilizados para esse trabalho já haviam sido coletados anteriormente por meio de uma pesquisa intitulada "Dimensões analíticas do fluxo de informação", do pesquisador professor Dr. Hilton Augusto Koch, Decano do Centro de Ciências biológicas e da saúde, aprovada pela Secretaria Municipal de Saúde - Plataforma Brasil -, pelo Parecer Consubstanciado do Conselho de Ética Profissional (CEP), sob o parecer número 481.944, de 22/11/2013.

Era preciso, então, uma atualização daqueles dados mencionados anteriormente. Para isso, após aprovação dessa pesquisa pelo Conselho de Ética Profissional da PUC-Rio, em meados de 2018, alguns meses após aprovação da banca de qualificação, foi solicitada autorização do Centro de Estudos e da direção do Hospital Municipal Miguel Couto para que a pesquisa fosse viabilizada.

Estando com todos os documentos em mãos, o Serviço Social daquela unidade, gentilmente, abraçou a pesquisa e cedeu todo material necessário para que, finalmente, a pesquisa de campo se realizasse.

O Hospital Municipal Miguel Couto fica localizado na Rua Mario Ribeiro, 117, bairro da Gávea, município do Rio de Janeiro, é vinculado ao Sistema Único de Saúde e responde à área programática 2.1. Em sua maioria, os funcionários são servidores públicos, embora tenha alguns contratados.

O referido hospital foi inaugurado em 25 de Outubro de 1936 pelo então presidente da república Getúlio Vargas. Hoje, a emergência conta com 61 
(sessenta e um) leitos e atende casos de emergência 24 horas por dia.

Dentro desse cenário, foi realizada a pesquisa de campo para fins deste estudo. $O$ acesso ao interior desse hospital não foi difícil, bastava identificar-se na recepção e a entrada eraliberada.

Sobre a coleta de dados ali realizada, precisaríamos que os assistentes sociais fornecessem os dados dos seus relatos de prática que são anexadas às fichas sociais. Esse movimento não apresentou nenhum desgaste para a pesquisa, pois todos os colegas foram colaborativos e tínhamos todas as autorizações em mãos.

Nessa perspectiva, optamos por acessar às fichas sociais, instrumento de trabalho do assistente social inserido em unidade hospitalar. Com esse documento, o profissional de Serviço Social preenche os principais dados do paciente, conforme especificação da própria folha. Dessa forma, são inseridos: nome completo do paciente, número do prontuário, data de internação, data de nascimento, número da identidade (ou outro documento com foto), endereço, referências familiares, renda, emprego ou trabalho, diagnóstico clínico, entre outros.Em anexo a esse documento, os assistentes sociais relatam todas as informaçõe scoletadas do paciente e de seus familiares, histórico de vida, histórico-hospitalar, informações fornecidas por outros profissionais, etc. Além disso, é lá que são disponibilizados todos os relatos das atividades profissionais realizadas pelos assistentes sociais.

Com as fichas socias mencionadas, trabalhamos com com a metodologia análise documental que, segundo Sá-Silva, et al (2009), diferente da análise bibliográfica em que um pesquisador utiliza documentos objetivando extrair deleinformações, ele o faz investigando, examinando, usando técnicas apropriadas para seumanuseio e análise; segue etapas e procedimentos; organiza informações a seremcategorizadas e posteriormente analisadas; por fim, elabora sínteses, ou seja, na realidade,as ações dos investigadores - cujos objetos são documentos - estão impregnadas deaspectos metodológicos, técnicos e analíticos.

Documento, por sua vez, segundo os mesmos autores,pode ser um material escrito, mas tambémdocumentos de natureza iconográfica e cinematográfica, ou de qualquer outro tipo de testemunho registrado, mas queoficialmente reconhecido, que serve de prova de um acontecimento, fatoou estado.

A análise documental propõe-se a produzir ou reelaborarconhecimentos e criar novas formas de compreender os fenômenos a fim de que seja possível 
interpretá-los, sintetizar as informações, determinar tendências e, na medida do possível, fazer a inferência.

Segundo Prates e Prates (2009), a metodologia análise documental contitui a análise de um ou mais documentos que não foram produzidos pelo pesquisador e são pré-existentes à investigação.

Para fins desta pesquisa, analisamos 63 (sessenta e três) fichas sociais de 2016 e 118 (cento e dezoito) fichas sociais de 2017, somando-se 181 (cento e oitenta e um) documentos analisados. Todos esses referem-se ao acompanhamento dos "casos sociais" com demanda para "alta social".

Tabela 1- Quantitativo de fichas sociais analisadas nesta pesquisa

\begin{tabular}{l|c}
\multicolumn{2}{c}{ FICHAS SOCIAIS DO HMMC } \\
\hline 2016 & 63 \\
\hline 2017 & 118 \\
\hline TOTAL & 181
\end{tabular}

Fonte: formulação própria, 2019.

Das 181 (cento e oitenta e uma) fichas sociais analisadas, 31 (trinta e uma) referiam- se a idosos, 43 (quarenta e três) a crianças e adolescentes e 107 (cento e sete) a adultos.

Dessas fichas sociais, foram coletadas todas as informações nelas disponibilizadas a fim de criarmos a caracterização dos pacientes atendidos pelo Serviço Social no HMMC, além da extração das informações mais relevantes a partir da leitura atenta dos relatos, objetivando destacar as interlocuções entre os profissionais dessa unidade, entre outras políticas, caminhos percorridos, etc.

Assim, conseguimos traçar caracterização dos usuários atendidos pelo Serviço Social com demanda para "alta hospitalar", sendo apresentados os seguintesresultados: 
Gráfico 1- Caracterização dos usuários atendidos pelo Serviço Social do HMMC entre 2016 e 2017 - Quanto à nacionalidade

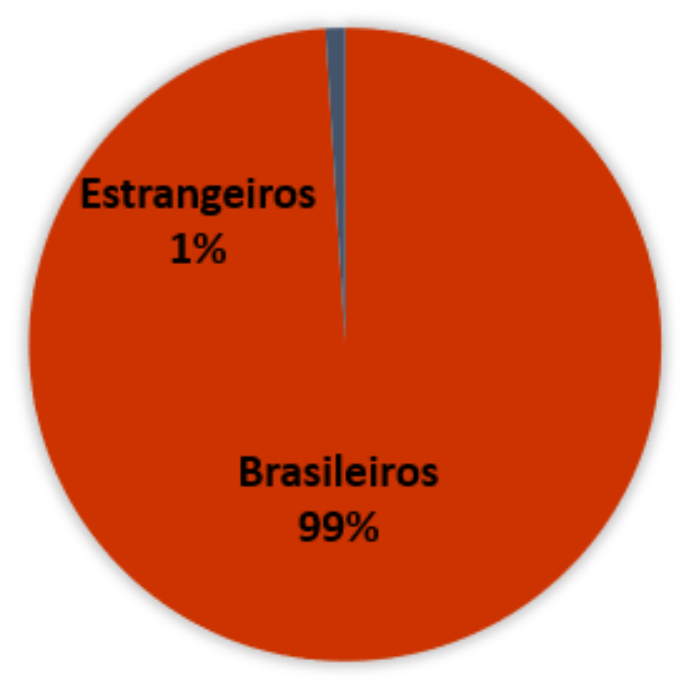

Fonte: Formulação própria (2019).

No gráfico apresentado acima, observamos que $1 \%$ da nacionalidade aqui apresentada é de estrangeiros. Esse número refere-se ao atendimento de um turista da República Tcheca, que foi vítima de agressão por arma sem projétil de fogo, durante um assalto na zona sul do município do Rio de Janeiro.

Por se tratar de uma área turística da cidade em que o hospital está localizado, poderia ser mais comum encontrarmos estrangeiros lá internados. Entretanto, não foi o que apareceu na análise desses dados. Ainda mais se levarmos em consideração que 2016 foi um ano de um grande evento ocorrido no Rio de Janeiro, as olimpíadas, em que a cidade recebeu muitos atletas e demais profissionais estrangeiros, além de turistas.

De fato, não houve ocorrência de nenhum acidente ou incidente envolvendo as apresentações ou pontos maisvisitadosparaque fosse mais comum o atendimento dessas pessoas, mas ainda assim, chama atenção o baixo nível de atendimento a estrangeiros em dois anos, o que pode ter alguns significados: ou esses turistas buscam atendimentos em unidades privadas de saúde, provenientes de seguros realizados anteriormente à viagem, ou mesmo procuram médicos particulares. 
Gráfico 2- Caracteriação dos usuários atendidos pelo Serviço Social do HMMC entre 2016 e 2017 - Quanto ao sexo

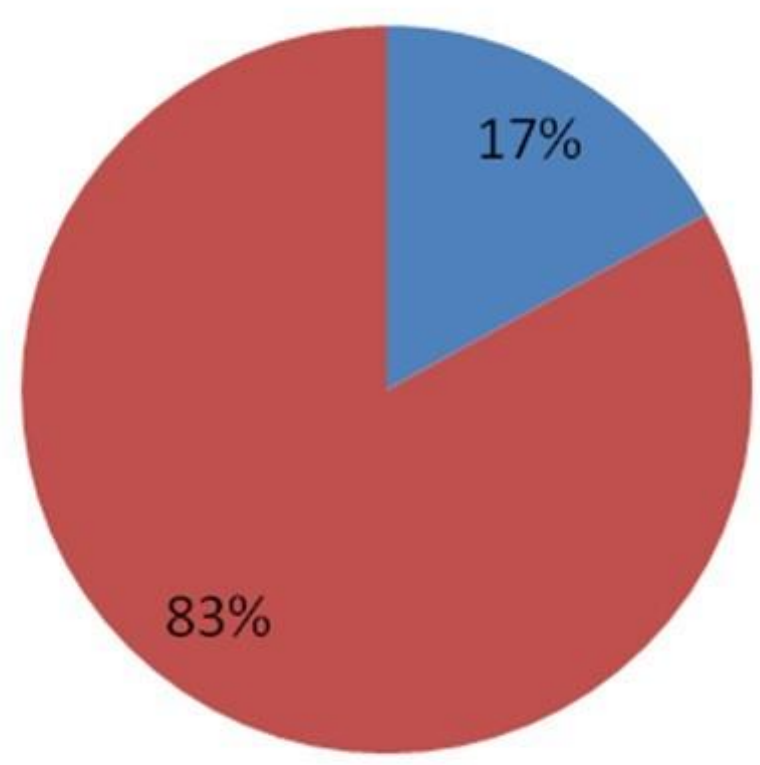

Mulheres

- Homens

Fonte: Formulação própria (2019).

A partir do gráfico 2, da porcentagem de pessoas atendidas, em que $83 \%$ correspondem a 150 homens e $17 \%$ a 31 mulheres, constatamos que $38,3 \%$ correspondiam ao total de homens adultos atendidos, liderando a caracterização de atendimentos, seguido de idosos (homens) atendidos, com 10,5\%.

Assim, podemos dizer que o caracterização de pessoas atendidas pelo Serviço Social com determinantes que culminavam em "casos sociais", em sua maioria, é de homens adultos.

Infelizmente, apesar de a ficha social constar espaço para o preenchimento com relação à cor/etnia do usuário, os preenchimentos realizados pelos assistentes sociais não destacavam a cor dos pacientes assistidos, o que poderia trazer dados muito relevantes para essa pesquisa ou àquelas que dessa sucederem, abrindo, assim, um importante debate sobre raça e etnia. Por isso, nessa pesquisa não foi possível realizar a caracterização dos pacientes. 
Gráfico 3- Caracteriação dos usuários atendidos pelo Serviço Social do HMMC entre 2016 e 2017 - Quanto à idade

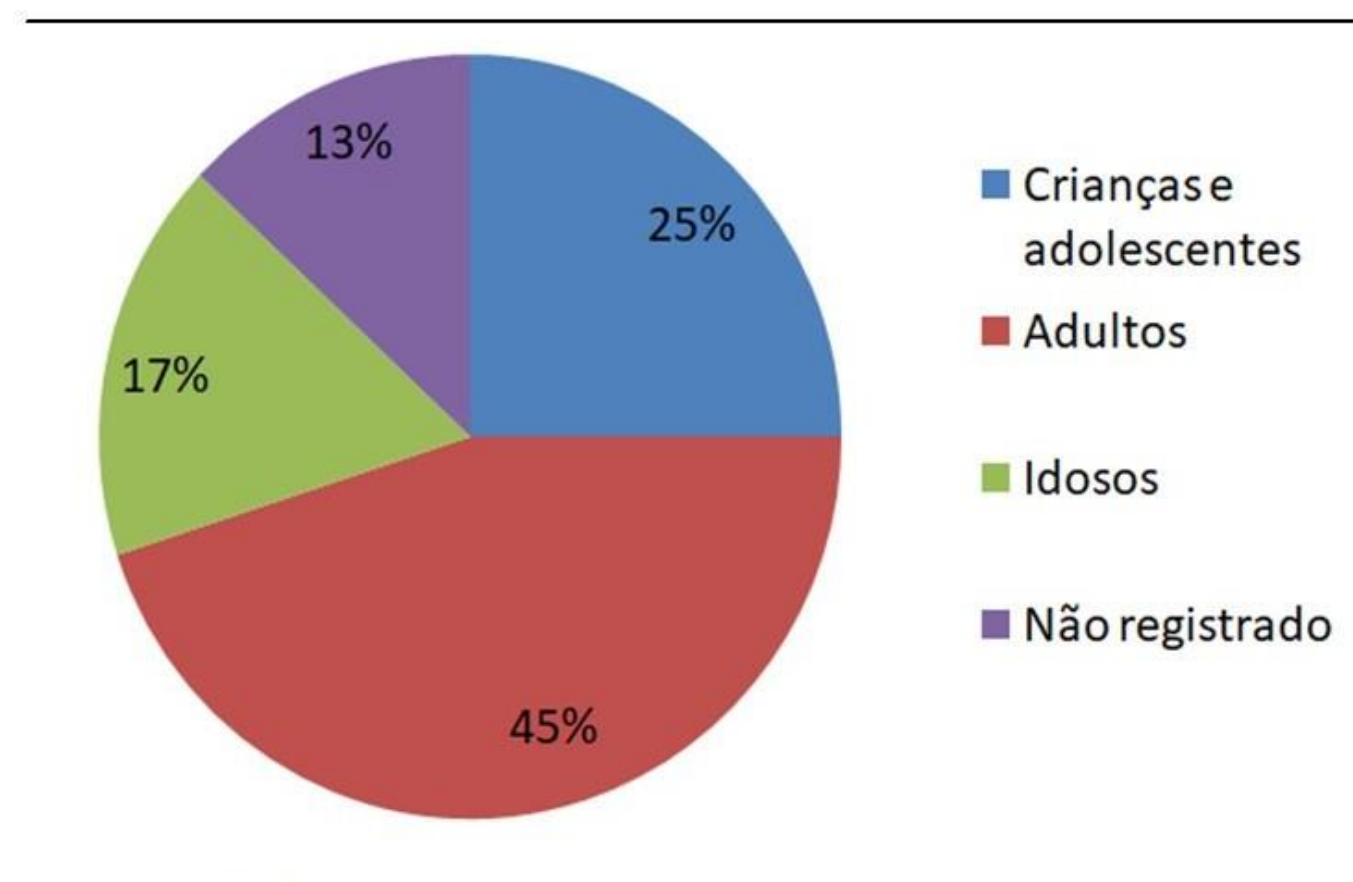

Fonte: Formulação própria, 2019

O gráfico 3, que representa as idades dos sujeitos atendidos pelo Serviço Social naquele período, mostra que, dos "casos sociais", $45 \%$ eram adultos e que em sua maioria esses eram homens na fase adulta. Isso pode contrariar muitas expectativas de que a maioria representaria os idosos.

Em seguida, o número de crianças e adolescentes atendidos pelo Serviço Social: $25 \%$. De fato, tratando-se dessa faixa etária, é comum que, em unidades hospitalares, os assistentes sociais participem de todo processo de internação e alta do paciente que possui menos de 18 anos, devido à garantia dos direitos estabelecidos pelo Estatuto da Criança e do adolescente.

Nessa faixa etária, os outros profissionais da equipe também costumam respeitar os relatos dos assistentes sociais quanto aos procedimentos por esses adotados e a atuação em casos de "alta social", diferentemente do que ocorre, em muitos casos, quando se trata de pessoas adultas, conforme veremos mais adiante. 
Gráfico 4- Caracteriação dos usuários atendidos pelo Serviço Social o HMMC entre 2016 e 2017 - Quanto à posse de ocumento de identificação

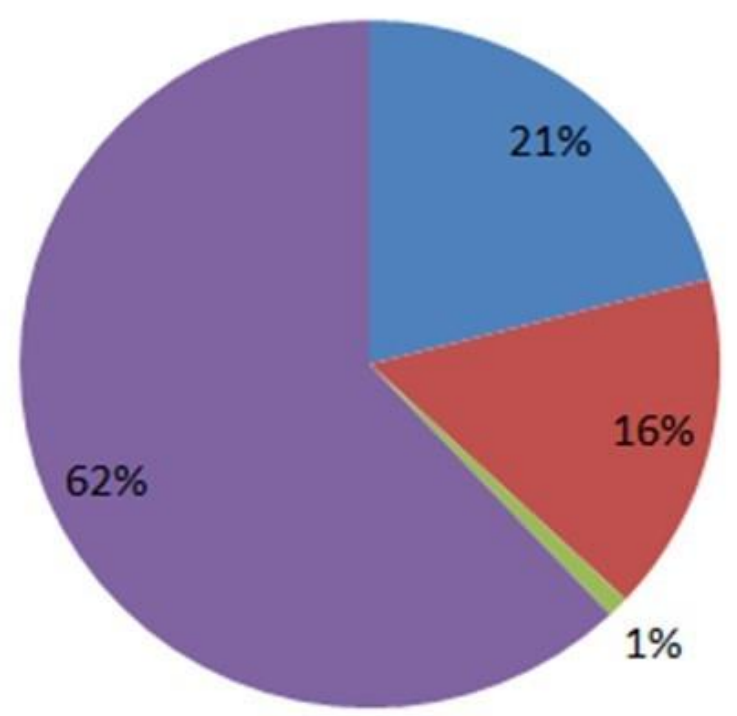

Possui algum documento

घ Não possui documento

Não possui registro de nascimento

Não registrado

\section{Fonte: Formulação própria (2019).}

No gráfico 4, observamos a porcentagem de sujeitos que detinham a posse de algum documento de identificação. Alguns dados chamam a atenção como, por exemplo, $1 \%$ dos atendidos não possuírem sequer registro de nascimento.

Segundo dados do relatório "Estatísticas do Registro Civil", do Instituto Brasileiro de Geografia e Estatística (IBGE), o número de crianças que não receberam a certidão de nascimento no primeiro ano de vida caiu para $1 \% \mathrm{em}$ 2014, o que indica uma tendência à erradicação do sub-registro civil de nascimento no Brasil. Em 2004, a taxa de crianças sem o documento era de 17\%. Observemos o gráfico aseguir: 
Gráfico 5- Estimativa do sub-registro de nascimentos

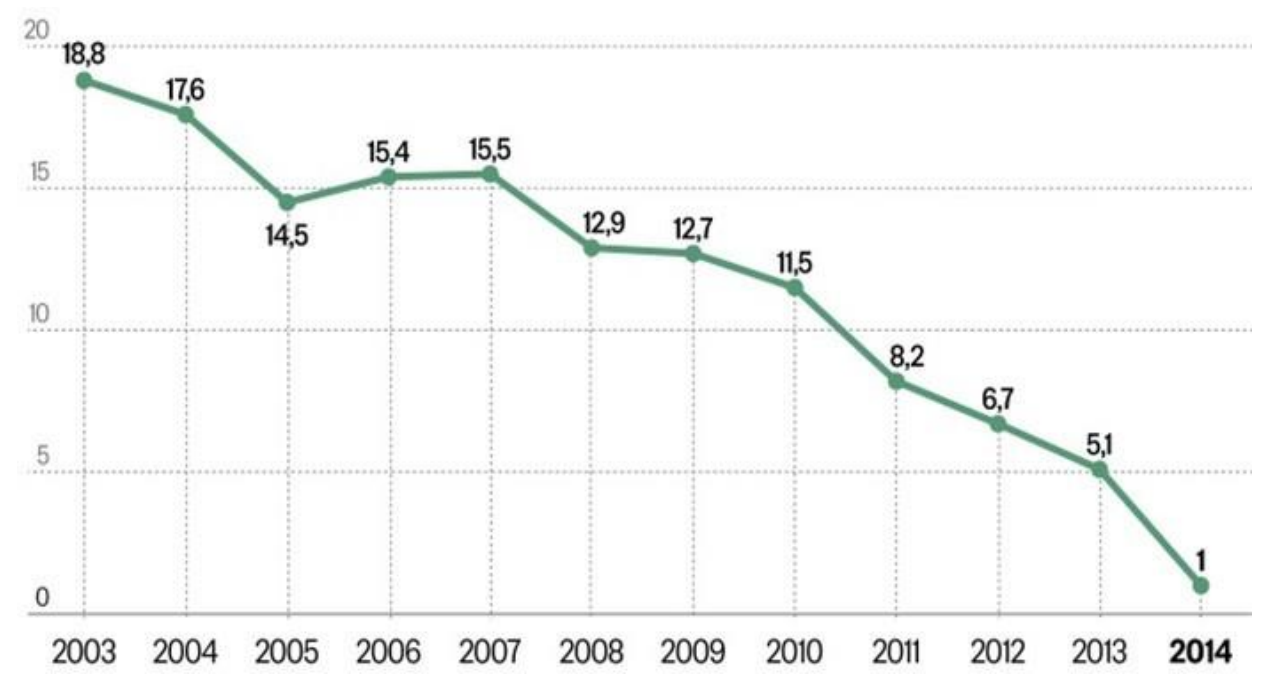

Fonte: IBGE (2016).

Nos dados colhidos para essa pesquisa, de fato observamos um baixo número de pessoas sem registro de nascimento. Apesar de desafiados em pleno 2019, é fruto do trabalho realizado pelo setor de sub-registros do Ministério Público que tem por objetivo erradicar o número de crianças sem registro de nascimento no país.

Outro ponto importante que precisamos mencionar é que, em $62 \%$ dos casos, os assistentes sociais não informaram sobre a posse de documentação. Essa informação, durante o atendimento de um caso em iminência de alta, pode ser bastante relevante em situações de solicitação de identificação de paciente, requerimento de algum benefício social, previdenciário, habitacional, entreoutros.

Embora a ficha social apresente espaço para outros dados para além desses que foram destacados aqui e abre espaço para livre relato, muitas informações não foram devidamente comunicadas, como as já descritas acimas e aqueles que não apareceram nos gráficos, alguns totalizando mais de $60 \%$ de falta de registro, como a informação quanto à posse de documento de identificação.

Almeida (1997) apresenta, em sua obra, diversos argumentos que mostram a importância da sistematização da prática do Serviço Social, tanto quanto a escrita acadêmica a partir das experiências profissionais, quanto por meio de relatos das práticas e embasamento teórico-metodológico. Em uma dessas fundamentações, o referido autor revela que: 


\begin{abstract}
A sistematização possui, ainda, um outro significado importante para a profissão, que é a sua contribuição nos processos de conquista de uma maior autonomia do Serviço Social no âmbito dos estabelecimentos onde atua. A maior e mais constante visibilidade da atividadeprofissional do assistente social sempre se constituiu num ponto de tensão para a própria profissão como na sua relação com a população e os demais profissionais. Neste sentido, a sistematização de seu trabalho não só auxilia o próprio reconhecimento pelo Serviço Social dos limites, dos avanços e da contribuição efetiva de sua atuação, como pode se tornar um componente importante de sua visibilidade social e institucional (Almeida, 1997, p.5).
\end{abstract}

E acrescenta que a sistematização deve ser um resgate de experiências que seja ilustrativamente rico dos procedimentos mobilizados como problematizadores das questões relativas ao exercício profissional, alçando a socialização da experiência a um patamar de discussão que contribua tanto para o amadurecimento intelectual como para o maior reconhecimento social do Serviço Social.

Nesse sentido, questionamos a falta de algumas informações importantes, que não foram expressamente relatadas nas fichas sociais em que analisamos. Para que o trabalho seja bem sistematizado e colabore com a visibilidade da atuação profissional do assistente social, como mesmo disse Almeida (1997) e também para facilitar a comunicação entre os pares em relação aos procedimentos adotados no plantão anterior, é preciso que o relato esteja mais bem detalhado e não faltem informações.

De todo modo, todas as descrições colocadas nas fichas sociais analisadas trouxeram importantes contribuições para esse trabalho no que diz respeito ao processo de "alta social", conforme veremos a seguir.

\title{
4.2.
}

\section{"Alta social” e Serviço Social: há possibilidade a partir da intersetorialidade?}

A alta hospitalar requer muitas situações para que seja viabilizada, dentre elas, o suporte familiar, a condição para dar continuidade ao tratamento, financeira e socialmente, condição de saúde adequada em regime domiciliar viver em local salubre, com boa nutrição, entre outras.

Para Mello (2013), a alta hospitalar é um processo complexo e desafiador para os profissionais de saúde, usuários e familiares. Trata-se da elaboração de um planejamento de intervenções educativas que visa o autocuidado e a autonomia dos usuários e os encaminhamentos necessários para a continuidade do tratamento, em outros pontos de atenção à saúde, em que processará seu acompanhamento após o retorno ao domicílio. Segundo a autora, a organização 
de um planejamento abrangente de alta hospitalar requer a identificação de necessidades sociaisdo usuário, dos insumos estratégicos ao seu caso e dos serviços especializados que estãodisponíveis.

O planejamento da alta hospitalar, visando o cuidado integral do sujeito, tem por objetivo orientar familiares, cuidadores e os próprios usuários para uma desospitalização mais segura e preparada. Para isso, é importante que os profissionais sejam capacitados, que se tenha uma rede de serviços sociais organizada e com equipe de referência, familiares orientados, entreoutros.

Para que sejam viabilizados todos esses cuidados, é de fundamental importância que todos os direitos sociais dos cidadãos sejam garantidos, especialmente àqueles referentes à Seguridade Social: Saúde, Previdência Social e AssistênciaSocial.

A partir desse ponto, entendemos que é relevante a participação de todos os setores nos cuidados com esse sujeito. Ou seja, uma gestão intersetorial eficiente pode ser muito contributiva na tentativa de promoção da integralidade da saúde de um paciente em iminência da alta.

Em nossa pesquisa, observamos que, na maioria dos casos, o primeiro passo dado pelos assistentes sociais, durante a intervenção junto a um paciente esperando por "alta social", é a busca por interface com outras políticas ou outros profissionais. Nesse sentido, dos 181 casos analisados para essa pesquisa, em $65 \%$ deles o Serviço Social buscou algum tipo de comunicação com outro setor como primeira medida a sertomada.

Sobre a intersetorialidade com a qual aqui estamos trabalhando, como bem esclarece Pereira (2014), o prefixo inter expressa uma característica unitária ou total, a partir de uma visão dialética. Dessa forma, a mera soma das partes ou a articulação entre elas, não propicia mudançaqualitativa.

É preciso, pois, que haja não um domínio de todas as disciplinas em seu sentido esvaziado, mas que elas se unam e ultrapassem conhecimentos e setores, a fim de que tenhamos uma intersetorialidade marcada pela abertura de todos os setores.

Compartilhamos do pensamento de Bravo (2011) de que a saúde, por estar diretamente relacionada às condições de vida e de trabalho da sociedade, articula e sofre as determinações da estrutura social.

Entendemos que a questão da saúde está diretamente ligada a expressões mais ou menos profundas da questão social, como o desemprego, a violência, a pobreza, etc.

Baseados na concepção ampliada de saúde, que traz a relevância dos 
componentes estruturais da sociedade, podemos dizer que as expressões da questão social estão diretamente relacionadas à condição de saúde da população. O local de moradia, as condições de trabalho, a qualidade de vida. Enfim, tudo isso irá influenciar o processo saúde-doença do indivíduo.

Por isso, a política de saúde, de forma isolada, não é capaz de promover saúde por si só e, assim, necessitaria da articulação com outros setores da estrutura estatal como a habitação, a Assistência Social, a educação, entreoutras.

$\mathrm{Na}$ nossa pesquisa, colhemos dados a partir de relatos dos profissionais de Serviço Social nas fichas sociais e buscamos compreender a narrativa de promoção da intersetorialidade e da interdisciplinaridade.

Todas as fichas sociais que analisamos, referem-se à participação do serviço social em situações de "casos sociais"13 em que esses profissionais participariam do processo de alta hospitalar, viabilizando a "alta" social após "alta médica".

Nesse sentido, observamos que o assistente social buscou articulação externa em quase todos os casos. Logo, podemos concluir que em meio a demanda por "alta social", a intersetorialidade é a principal referência em busca da solução do caso, ainda que não seja a única.

Em nossa pesquisa, nos casos em que o serviço social da unidade aqui pesquisada esteve presente no acompanhamento da alta hospitalar, em $80 \%$ (oitenta por cento) dos casos, houve algum tipo de interlocução com outra política, sendo apresentado o seguinte resultado:

13 Já tratamos do assunto "casos sociais" anteriormente. 
Gráfico 6- Intersetorialidade no HMMC entre 2016 e 2017 - casos de "alta social"

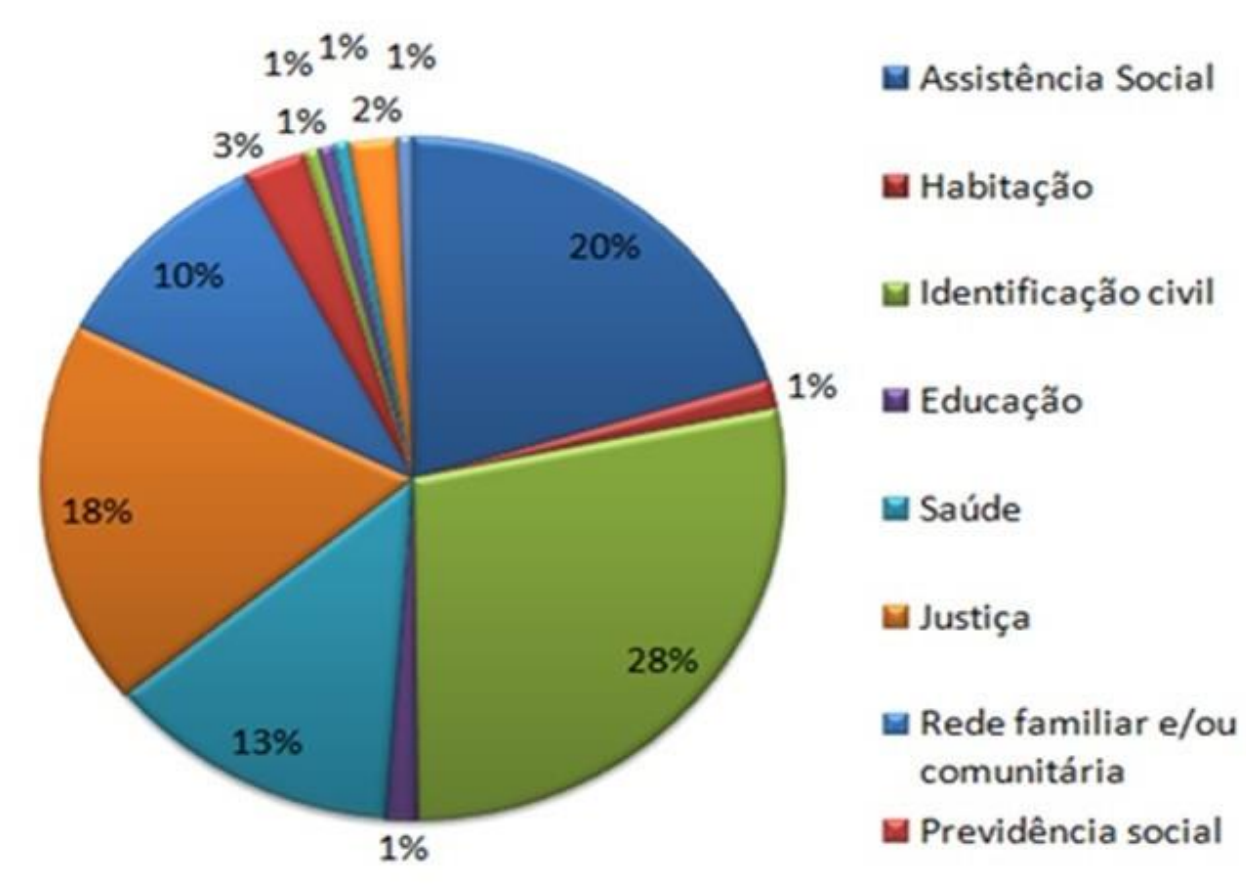

Fonte: Formulação própria (2019).

Como visto, a maior articulação entre o serviço social daquela unidade naquele período está ligada à identificação civil, primeiramente. Isto é, $28 \%$ (vinte e oito por cento) da articulação com a rede envolve instituições como Departamento de Trânsito - Detran - e o Instituto de Identificação Félix Pacheco - IIFP -, ambos do governo do estado. Em seguida, com 20\% (vinte por cento), temos a articulação com a Assistência Social, como os CRAS, CREAS, Organizações Não governamentais (ONGs), entre outras. Após, encontramos a justiça com 18\% (dezoito porcento).

As articulações com o Detran e com o IIFP referem-se a tentativas de reconhecer pacientes que deram entrada sem identificação, devido à perda de memória ou condição de debilidade na saúde. Portanto, podemos dizer que a maior solicitação dos outros profissionais para interação em demandas relacionadas à alta hospitalar, refere-se a esses casos.

Para diálogo com o DETRAN, a comunicação se fazia via e-mail com pedido de ofício devidamente assinado pela direção hospitalar. Nesse caso, apesar da solicitação inicial ter partido do Serviço Social, parece-nos que havia pouca autonomia desse profissional ou muita burocracia para protocolar tal solicitação e esse formulava-se mais como um interlocutor entre a gestão e o 
Detran do que como o responsável pelo acompanhamento docaso.

Segundo Fortes (2017),

A relação contratual do empregado especializado com seu empregador pode definir se sua autonomia na instituição contratante e se seu relacionamento com os usuários será absoluta ou relativa. Para a maioria dos contratos atuais, pode-se dizer que ela é quase sempre relativa na condução de suas ações profissionais, devido aos vínculos trabalhistas precarizados e permeados pelos interesses de grupos sociais abastados que incidem nas condições que circunscrevem o trabalho. Portanto, as condições de trabalho e as relações sociais interferem no processamento das ações e nos seus resultados. Quanto mais fragilizado for o contrato trabalhista, menor será a autonomia do profissional e pode intervir na realidade sob a perspectiva de contribuir para a garantia de direitos da classe trabalhadora (Fortes, 2017, p.298).

No caso específico do Hospital Municipal Miguel Couto, o hospital aindanão conta com gestão privada, ou seja, não há uma Organização Social de Saúde - OSS - que direcione a unidade, exceto, para atuação do Programa de Atenção Domiciliar ao Idoso - PADI - e na Coordenação de Emergência Regional - CER. Isso significa que os funcionários daquela unidade são servidorespúblicos.

Entretanto, o vínculo empregatício por si só não está diretamente relacionado com a questão da autonomia. Como revela lamamoto (2004, p. 18), embora os assistentes sociais possam atribuir uma direção social ao seu exercício, a interferência dos organismos empregadores ocorre por meio (do estabelecimento de metas, normas, atribuições,condições de trabalho e relações de trabalho. $E$ isso pode ocorrer com qualquer modalidade de gestão: pública ou privada.

Nessa situação de pedido de identificação de paciente, foi observado retorno quase imediato do DETRAN e sucesso em quase todos os casos, exceto quando envolvia óbito, saída à revelia ou paciente que fizera identificação fora do estado do Rio de Janeiro.

Com relação à articulação com a Assistência Social, refere-se à tentativa de regulação de paciente para possível vaga em instituição de acolhimento, busca por referências familiares de usuários de determinada unidade vinculada à política de Assistência Social e encaminhamentos para inserção no Programa Bolsa Família e outros benefícios.

No caso exposto acima, foi observada dificuldade em conseguir vaga em instituição de acolhimento, possivelmente devido ao sucateamento dessa política nesse sentido. Quanto aos encaminhamentos, não houve relato de retorno com êxito na solicitação do direito social. 
$\mathrm{Na}$ terceira maior articulação encontrada nesta pesquisa, verificamos a problemática da "judicialização da saúde". Ou seja, quando há uma falha em uma política social, a tendência é recorrer à justiça, a fim da viabilização do direito adquirido constitucionalmente. A problemática, nesse caso, refere-se ao sucateamento das políticas sociais que impossibilitam uma intersetorialidade eficiente.

Segundo Ribeiro (2014), a "judicialização da saúde" ocorre ematendimento aos interesses do capital e contrariando os direitos conquistados na Constituição, restando à população usuária das políticas sociais, em especial, das políticas de saúde, ao não encontrar respostas para as suas demandas, o acionamento da justiça.

É a cobrança da população pelo direito à proteção social pelo Estado, a fim de que sejam acessados tratamentos, medicamentos e tecnologias não disponibilizadas pelo Sistema Único de Saúde.

Ainda de acordo com Ribeiro (2014, p. 16),

O debate sobre a judicialização da saúde envolve aspectos fundamentais de discussão como gestão, orçamento, direitos, acesso, integralidade. É também um debate polêmico, pois envolve uma tensão entre o direito coletivo e o direito individual, na medida em que, através do mandado de segurança, é possível atenuar as violações da vivência do direito à saúde de um indivíduo ocasionada pela falta de acesso, mas ao mesmo tempo, um excesso de demandas judiciais prejudica o exercício da cidadania, com a desresponsabilização do Estado pela oferta dos serviços com qualidade. Um mandado de segurança pode, em curto prazo, promover acesso a um indivíduo, mas em longo prazo, pode não significar ganho para o coletivo, na medida em que o gestor da saúde tomará providência apenas para quem entrou na justiça e cuja decisão deve acatar, não fazendo mudanças estruturais e necessárias nos serviços de saúde que podem ser acessados portodos.

Não menos importante, é preciso mencionar que em quarto lugar, encontramos tentativa de articulação com outros níveis da saúde ou mesmo outras especialidades como a saúde mental, a estratégia saúde da família e o consultório na rua.

As unidades básicas de saúde, instituições de grande apreço da promoção da saúde, é o lugar prioritário para continuidade dos cuidados em saúde, uma vez que a atenção terciária tradicionalmente possui demandas que não costumam criar vínculos entre os usuários, os profissionais e a instituição, já que, para atendimento, na maioria dos casos, é necessário submissão ao leitoe este requer maior rotatividade, principalmente, quando temos esvaziamento de unidades de referência para média e alta complexidade e precariedade da política de saúde. 
Em relação à interação entre os profissionais, observamos pouco entrosamento entre as equipes. Em geral, essa relação se resumiu em troca de informações sobre o paciente, solicitação de atendimento especializado ou solicitação de documentos específicos. Esse fato corrobora com a perspectiva de Pereira (2014), já mencionada anteriormente, em que isso revela a mera soma das partes ou a articulação entre elas e não provoca uma mudança qualitativa.

Gráfico 7- Interdisciplinaridade entre assistentes sociais e demais equipes do HMMC

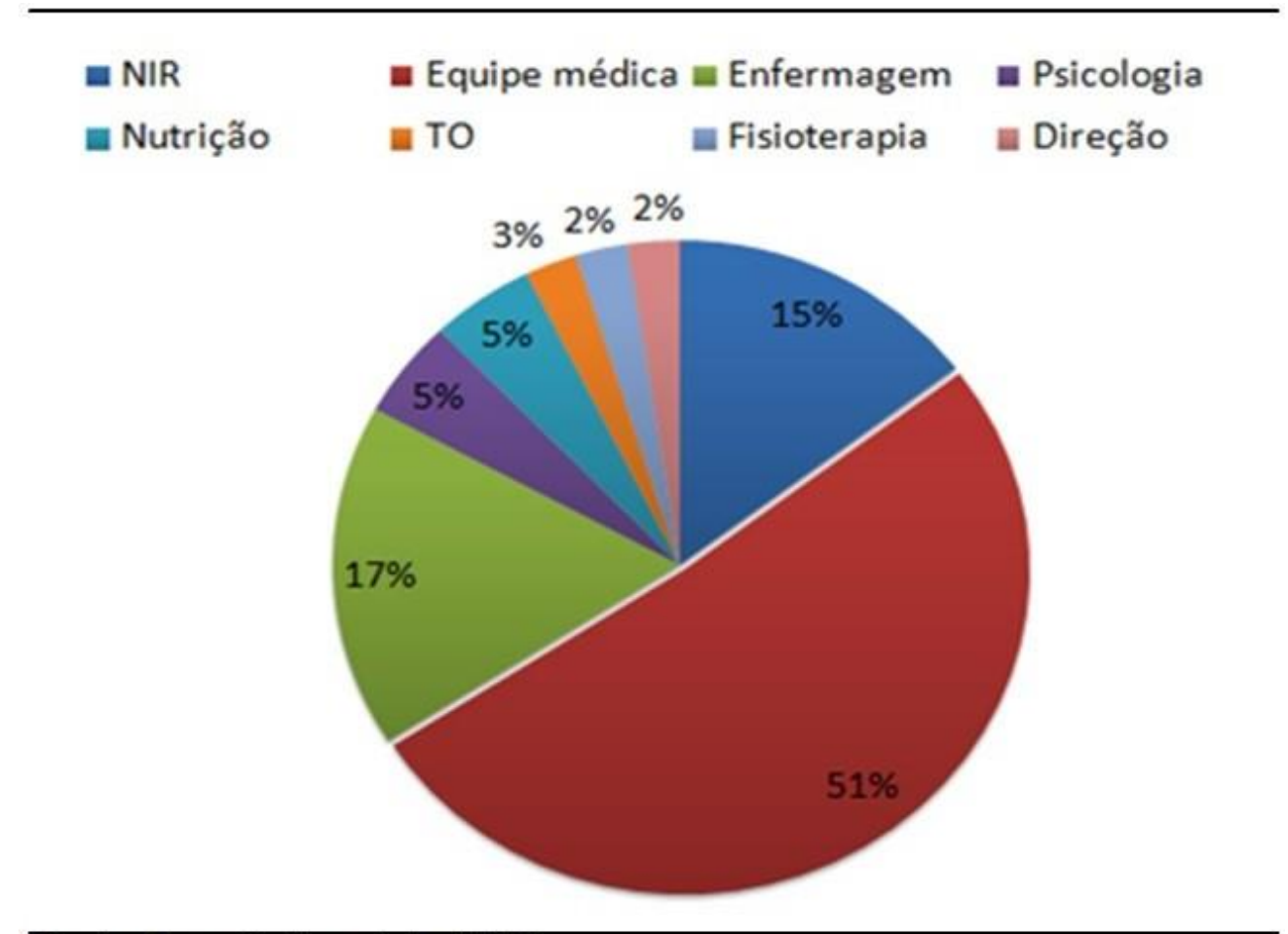

Fonte: Formulação própria (2019).

O gráfico acima apresenta as principais articulações do Serviço Social com as demais equipes em caso de "alta social". Como podemos observar, as principais interações ocorremcom a equipe médica, correspondendo 51\% (cinquenta e um por cento). Nos casos apresentados nos documentos analisados, referem-se a pedidos de pareceres clínicos ou solicitação de atendimento do Serviço Social por parte da equipe médica.

Em seguida, observamos a interdisciplinaridade com a equipe de enfermagem. Na maioria das vezes, essa interação se dava em busca de conhecer o quadro clínico do paciente.

Em terceiro lugar, observamos a interação com o Núcleo Interno de 
Regulação - NIR - setor onde se encontram os profissionais responsáveis pela internação e transferência do paciente. Nesse caso, ao fazer essa aproximação, que em todos os casos partia do Serviço social, o interesse era a localização de paciente em outra clínica dentro do mesmo hospital ou pedido de regulação de paciente para transferência.

Mais uma vez, observamos o mero entrosamento entre os envolvidos e pouca articulação em busca do conhecimento do caso e um atendimento de qualidade.

No debate sobre intersetorialidade na promoção da saúde, Carvalho (2015) entende que essa é uma ferramenta a ser utilizada, mas que muitas dessas iniciativas são informais e não envolvem um trabalho prévio de planejamento, sendo ações definidas por apenas um setor.

Para o autor citado acima, a intersetorialidade envolve muitas complexidades, como:

- Dificuldade de conciliar os tempos institucionais dos váriossetores;

- $\quad$ necessidade de comprometimento e envolvimento setorial;

- $\quad$ falta de sustentabilidade das açõese;

- $\quad$ inexistência de protocolos que norteiem o desenvolvimento de ações intersetoriais

Além disso, é necessária uma mudança nas formas de atuação, operação política e gestão das instituições e das pessoas que as integram.

Dessa forma, consideramos que chamar uma mera articulação entre os setores é um descompromisso com a luta por políticas sociais de qualidade e uma irresponsável responsabilização dos profissionais em relação ao fazer funcionar a tal intersetorialidade.

Do mesmo modo, segundo Carvalho (2015), apesar das ações intersetoriais serem essenciais para atuar sobre questões estruturais da sociedade e que interferem no processo saúde-doença-cuidado, elas não possuem sustentabilidade devido a baixos níveis de adesão ao diálogo e pactuação de agenda.

A seguir, veremos como a intersetorialidade tem aparecido em casos de "alta social" no HMMC e se tem contribuído, de alguma forma, com a resolutividade dos casos. Além disso, faremos reflexões sobre esse termo bastante difundido na área da saúde ("alta social”), seu significado, seu conceito, importância, etc. 


\section{3. \\ "Alta Social" e Serviço Social no HMMC}

Todo paciente que entra em uma unidade hospitalar, tem apenas um desejo: receber alta. Isso deveria significar estar mais bem disposto, com boa saúde e com sentimento de bem-estar. Entretanto, há casos em que a alta hospitalar pode não estar diretamente atrelada a esses fatos. E é com esse ponto que buscamos entender como a alta bem planejada e articulada com equipe multidisciplinar e com a rede pode mudar o rumo do cuidado em Saúde dos usuários.

Dentro de uma unidade hospitalar, convencionou-se a dividir a alta em algumas terminologias, como a "alta médica" e a "alta social". O fato é que essa segregação para tratar da alta de um único sujeito acaba não promovendo o cuidado integral da saúde, conforme diretriz do Sistema Único de Saúde.

Para se efetivar uma alta hospitalar é preciso que os profissionais envolvidos no atendimento ao usuário estejam de acordo e isso envolve a equipe médica, enfermagem, assistentes sociais, psicólogos, nutricionistas, fonoaudiólogos e todos os outros. Assim, teríamos um olhar mais integral sobre a complexidade que envolve o cuidado em Saúde.

Entretanto, no interior das unidades hospitalares, é comum ainda ouvirmos, entre as equipes multiprofissionais e os próprios assistentes sociais, o termo "alta social". Essa alta, segundo Cunha (2018), refere-se àquelas em que há questões de cunho social que dificultam ou impossibilitam o retorno do paciente à sua residência de origem.

Com isso, enfatizamos que questionamos a segregação do cuidado em Saúde e vislumbramos o cuidado integral que culmina em alta hospitalar com a ciência de todos os saberes envolvidos, não exclusivamente o biomédico.

Nas palavras de Leal e Xavier (2014):

Neste sentido, a alta social, é tema de discussões e até mesmo de impasses na equipe, justamente por desconhecerem o trabalho desempenhado pelo assistente social, e consequentemente seus encaminhamentos. O que acaba por reafirmar a lógica do modelo biomédico, separando o sujeito em partes, e não na sua integralidade, o que vai, portanto, contra o conceito de saúde ampliada. Esse desconhecimento se dá a priori pela indisponibilidade de diálogo entre as diferentes categorias profissionais, permeadas por relações hierarquizadas calcadas sob a égide do modelo biomédico ainda presente e latente na instituição hospitalar (Leal e Xavier, 2014, p. 9).

O Conselho Federal de Serviço Social, em 2010, também estabeleceu essa diferenciação entre "alta médica" e "alta social", mas salienta que elas 
devem ocorrer demaneira concomitante, de modo que, em situações em que o usuário já tiver recebido a "alta médica" sem condições de "alta social", caiba (cabe) ao profissional de Serviço Social notificar à equipe, registrando no prontuário a sua intervenção, de forma a ratificar o caráter do atendimento em equipe, com o objetivo de estabelecer interface do familiar com a equipe.

O referido Conselho orienta ainda que quanto à atuação do Serviço Social no processo de alta e remoção dar-se-á a partir da realização de um estudo social, que vai determinar se há demanda para a intervenção direta do profissional neste processo.

Ou seja, o próprio Conselho Federal da categoria orienta a participação dos assistentes sociais em demandas de alta, mas apenas em casos em que ele próprio identifique sua necessidade. $\mathrm{E}$ ainda esclarece que o profissional responsável pela alta e pelos seus procedimentos deve ser o médico e não o assistente social. O profissional de Serviço Social pode ser um interlocutor entre os usuários e a equipe de saúde com relação aos determinantes sociais, visto que o respeito pela diversidade é um princípio que deve fundamentar tanto a sua formação como o seu trabalho profissional.

De fato, reconhecemos que a equipe multiprofissional tende a dar maior importância à categoria dos assistentes sociais quando eles são acionados em caso de impasse para alta hospitalar, quando há impedimento de caráter transversal às questões de saúde. Mas entendemos que para alcançarmos o cuidado integral da saúde seria preciso que esse profissional, assim como todos os outros envolvidos, estivesse a par dos procedimentos adotados desde a internação até aalta.

Além disso, entendemos que o paciente e familiares estejam de acordo com o momento da alta, após terem recebido todas as orientações e encaminhamentos. Isso porque o usuário, na condição de sujeito protagonista da sua história, deve ser autônomo para decidir sobre os rumos do tratamento de saúde a ser adotado e a que procedimentos deve ser submetido.

No ambiente hospitalar, a "alta social" surge posteriormente ao acompanhamento de um "caso social" pelo assistente social. Essa terminologia é adotada para os pacientes que passam por alguma situação voltada às problemáticas de cunho social. De acordo com o estudo realizado por Guerra (2015), as situações sociais passam a constituir-se casos sociais quando:

1) A alta de um utente éprotelada;

2) No caso de este não possuir rede de suporte formal que permita a continuidade dos cuidados após a altahospitalar; 
3) Sempre que a complexidade das situações impeça a sua resolução, influenciando bem-estar e saúde doindivíduo.

Em 30 de dezembro de 2013 foi decretada a portaria № 3.390 que institui a Política Nacional de Atenção Hospitalar (PNHOSP) no âmbito do Sistema Único de Saúde (SUS), estabelecendo-se as diretrizes para a organização do componente hospitalar da Rede de Atenção à Saúde (RAS). Essa Política Nacional de Atenção Hospitalar ressalta que a alta responsável consiste no processo de planejamento e transferência do cuidado de uma unidade de saúde (hospitalar ou ambulatorial) para outra(s), de modo a propiciar a continuidade do cuidado por meio de:

I) orientação de usuários e familiares/cuidadores, reforçando a autonomia do sujeito, proporcionando oautocuidado;

II) articulação com os demais pontos de atenção das Redes de Atenção à Saúde, em particular a Atenção Básicae;

III) implantação de mecanismos de desospitalização, visando alternativas às práticas hospitalares, como as de cuidados domiciliares pactuados nas Redes de Atenção àSaúde.

A Política Nacional de Atenção Hospitalar mostra que o indicador de alta responsável está relacionado com a integralidade do cuidado, que exige a articulação entre os trabalhadores de uma mesma equipe e serviços existentes no interior dos hospitais, bem como entre as diferentes unidades de saúde que compõem as Redes de Atenção à Saúde. Para oferecer um cuidado com qualidade é necessário combinar a intencionalidade de concretizar um modelo de atenção voltado às necessidades e riscos dos usuários com a capacidade de identificar recursos e combiná-los a diversas variações possíveis, de modo a planejar e pactuar entre os responsáveis a oferta destes recursos.

Há orientação, ainda, para a elaboração e a implementação de um Protocolo de Alta Responsável. Assim, o estabelecimento de uma linha de cuidado se tornaria um mecanismo viável de favorecimento de alta hospitalar responsável e de contrarreferência. O planejamento estipulado para o protocolo poderia ser capaz de promover a articulação dos diferentes pontos de atenção em saúde e o cuidado integral ao indivíduo.

A questão da "alta social" pressupõe, antes de tudo, uma análise crítica sobre esse processo. Com a demanda por rotatividade de leitos e redução de custos em meio à agenda neoliberal, é possível observar maior preocupação com uma intervenção rápida nos casos que demandem "alta social", como 
mostram as reportagens do site do Jornal Tribuna do Paraná/Brasil e DN de Portugal, exposta nas figuras 4 e 5.

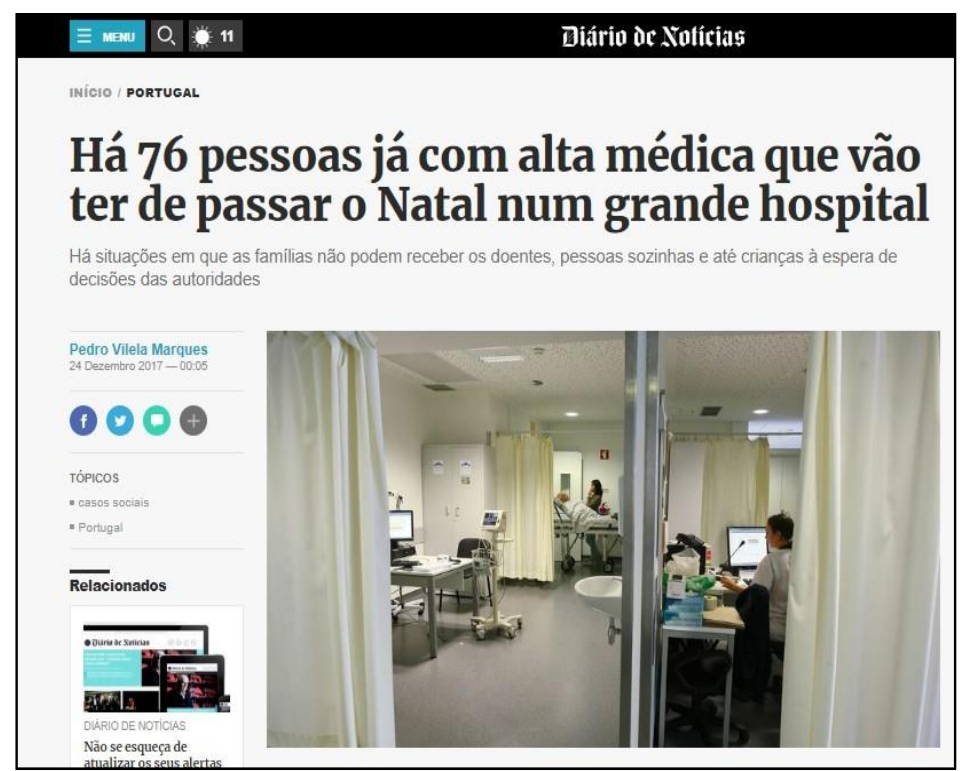

Figura 4- Portugal - Notícia: Pessoas com alta médica permanecem no hospital Fonte: Jornal Diário de Notícias de Portugal (2017).

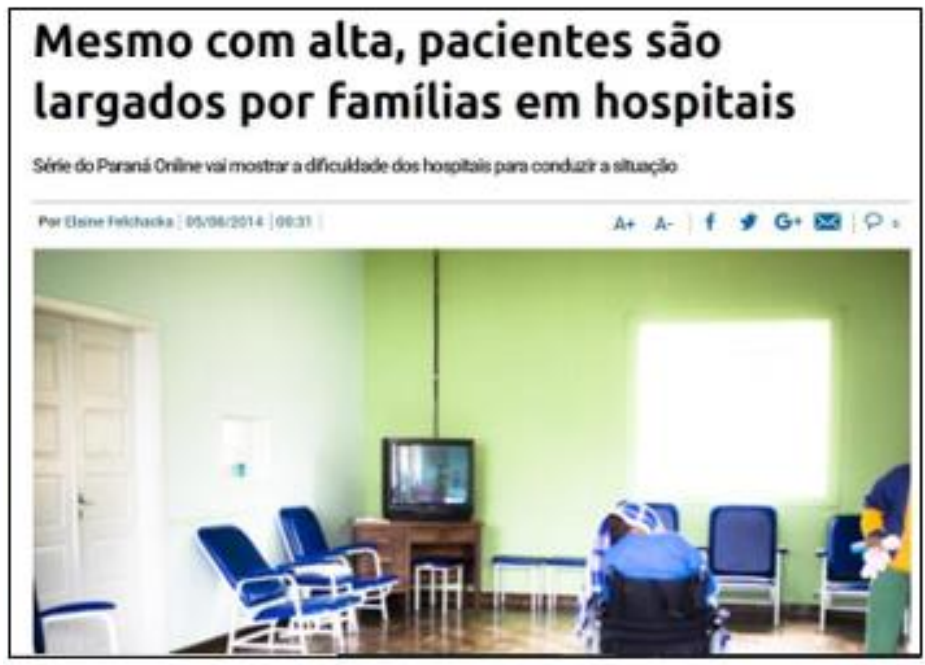

Figura 5- Paraná online - Notícia: Mesmo com alta, pacientes permanecem internados.

Fonte: Paraná online (2014) 
Segundo Vasconcelos (2012), as demandas que historicamente são dirigidas aos assistentes sociais que trabalham em unidades de saúde são as apresentadas na figura 6 .

\section{rig் Alta Social}

\section{Remoção de paciente}

\section{仍 Participação em questões de óbito}

Figura 6- Demandas historicamente dirigidas aos assistentes sociais que trabalham em unidades de saúde.

Fonte: Formulação própria, 2019 (a partir deVasconcelos, 2012).

Das três questões apontadas anteriormente, entendemos que todas fazem parte da liberação do paciente do leito hospitalar e, as três ${ }^{14}$ podem, ou melhor, deveriam envolver a intervenção do assistente social.

A seguir, vamos detalhar os principais fatores que determinaram os entraves para alta em nossa pesquisa. Porém, gostaríamos de esclarecer que optamos por separar os usuários em três categorias: criança e adolescente, adulto e idoso. Isto foi feito, pois precisamos entender as demandas que são próprias de cada faixaetária.

14 A questão da participação em comunicação de óbito pelo assistente social pode ser melhor observada na Resolução n. 49/96 do CRESS em que direciona a competência desse profissional como complementação de ações prestadas, tal qual orientação sobre sepultamento, direitos previdenciários dos dependentes, etc. 
Gráfico 8- Principais demandas de crianças e adolescentes atendidos pelo Serviço Social

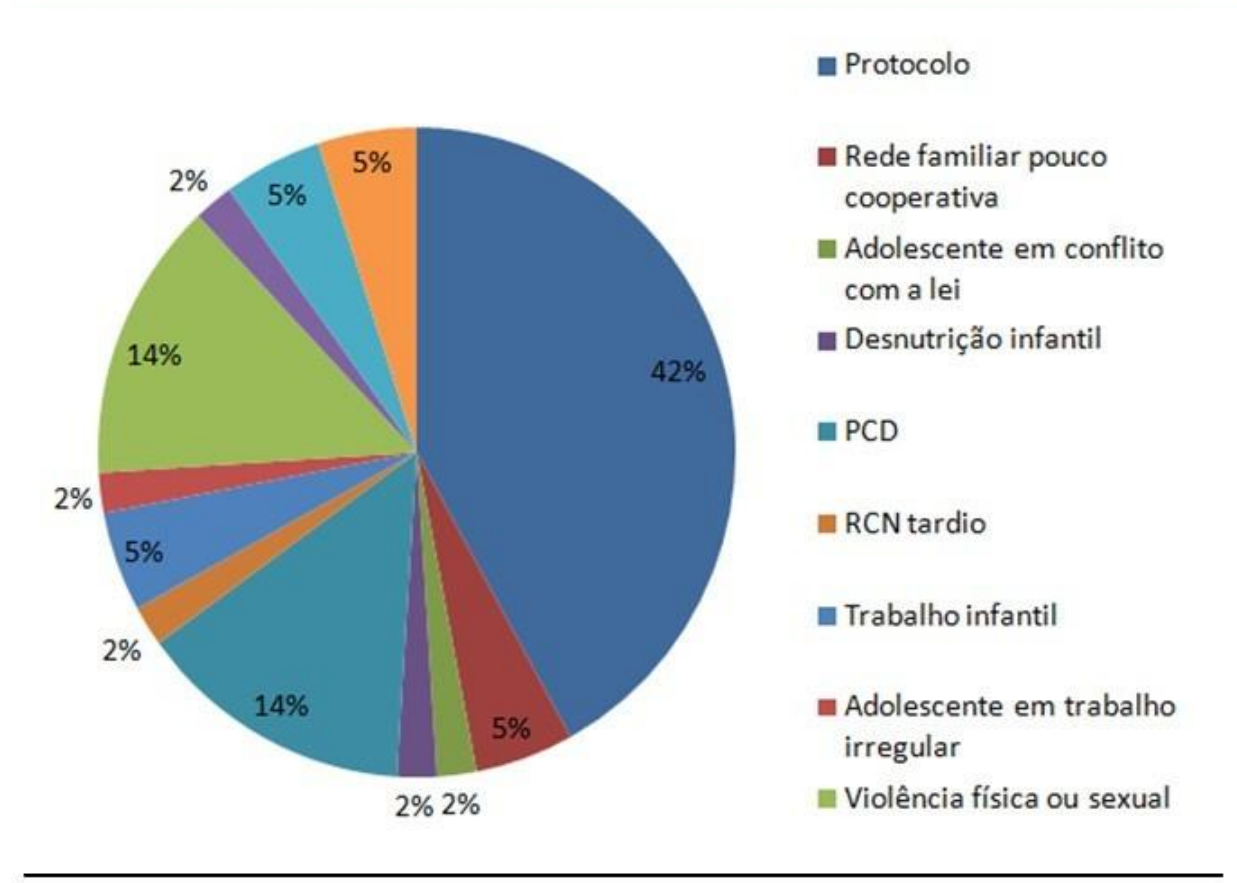

Fonte: Formulação própria (2019).

No caso crianças e adolescentes, como já explicado anteriormente, é comum o acompanhamento de toda equipe multidisciplinar desde o momento da internação até a alta hospitalar. Então, no gráfico 8, estão todos os atendimentos realizados pelo Serviço Social do HMMC, no período aqui estudado.

Como observamos, $42 \%$ não apresentavam demandas específicas para o Serviço Social e o atendimento se deu no sentido de se fazer cumprir o protocolo: acolhimento, orientação, estudo do caso, abertura da ficha social e observação de demandas.

Quanto aos demais casos, 5\% dos casos, referem-se a adolescente com rede familiar pouco cooperativa, envolvendo conflitos; outros $5 \%$ envolvem acompanhamento de adolescentes em conflito com a lei que, em geral, são meninos apreendidos durante confronto com a política; foi apresentado $2 \%$ dos casos de crianças com desnutrição infantil, 14\% de crianças com deficiência, como casos de microcefalia, em que os familiares foram orientados quanto aos direitos previdenciários; outros $2 \%$ eram de crianças com registro de nascimento tardio que receberam orientação do Serviço Social e conseguiram ter esse direito viabilizado; $5 \%$ dessas crianças apresentaram situação de trabalhoinfantil; $2 \%$ eram adolescentes em situação de trabalho irregular; 14\% dessa população foram vítimas de violência física e/ou sexual e foram 
acompanhados pelo Serviço Social; $5 \%$ foram notificados como negligência e $2 \%$ eram adolescentes em situação derua.

O gráfico apresenta ainda um dado de $2 \%$ que são referentes a demandas apresentadas ao Serviço Social para que fosse emitido documento comprobatório de acompanhamento para abono de falta dos pais no trabalho. Entretanto, cabe aqui ressaltar que, assim como apresentado na pesquisa de Vasconcelos (2012), essa também não é uma demanda exclusiva do Serviço Social, mas é comum que os familiares procurem esses profissionais voluntariamente e, às vezes, mal orientados por outras categorias.

Gráfico 9- Principais demandas dos adultos (18 a 59 anos) atendidos pelo Serviço Social

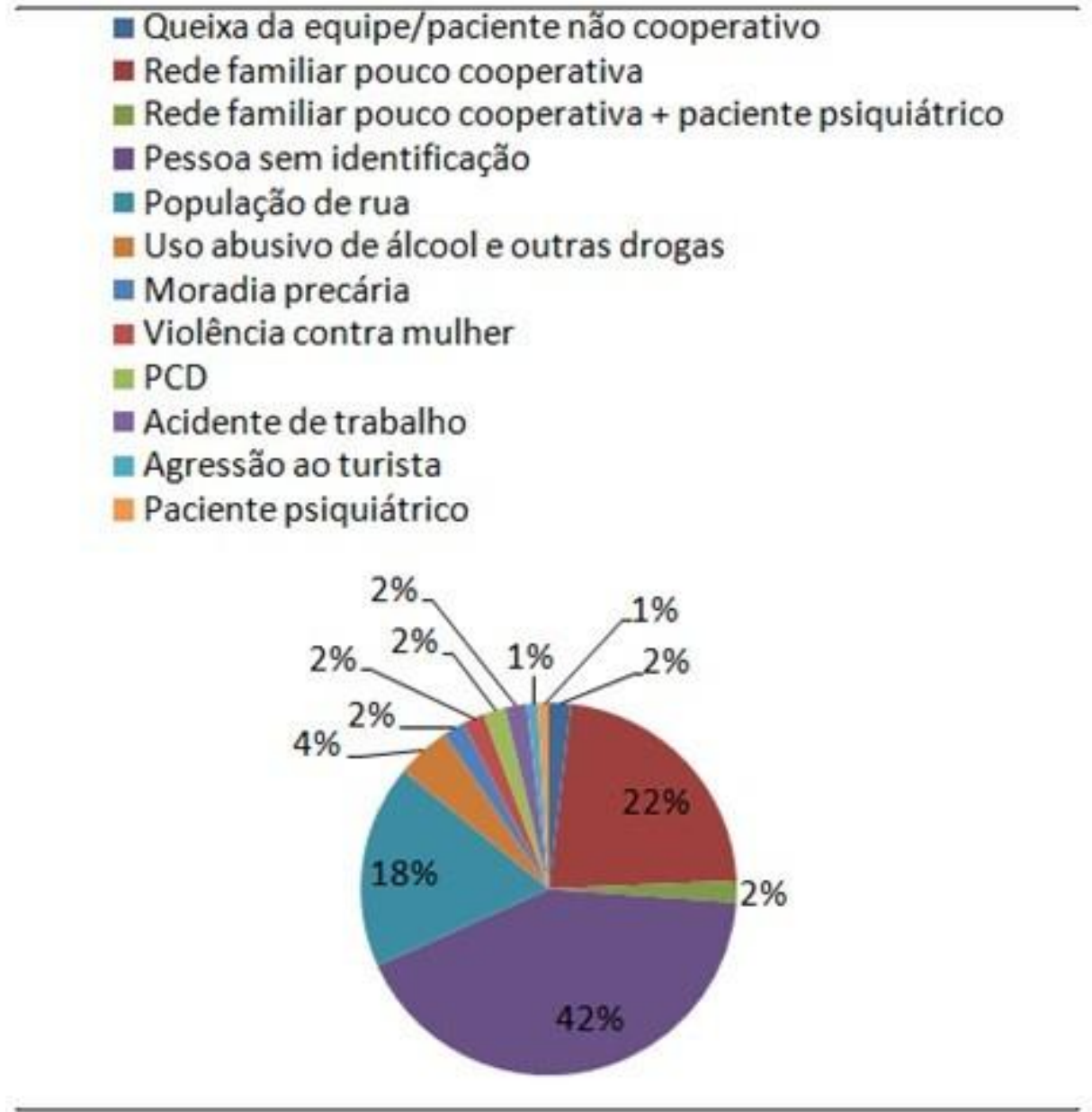

Fonte: Formulação própria (2019).

O gráfico anterior mostra a população da fase adulta e que foram atendidas pelo Serviço Social do HMMC entre 2016 e 2017. Todos os casos foram considerados "casos sociais" pela equipe multidisciplinar e demandavam ações para viabilização da alta por parte do Serviço Social. 
Desses mencionados, $42 \%$ da população da fase adulta e que foram atendidas pelo Serviço Social do HMMC entre 2016 e 2017 chegaram ao hospital sem identificação.

Nesses casos, o Serviço Social acionou o Detran para identificação do paciente, assim como a DDPA, quando necessário. Em todas essas situações, $47 \%$ dos sujeitos não foram identificados, isso inclui aqueles que foram a óbito, saíram à revelia ou foram liberados pelo médico, sem articulação com os demaisprofissionais.

Além disso, chama atenção que $24 \%$ tiveram alta prorrogada por falta de referência familiar ou família não cooperativa. Isso quer dizer, que não houve acolhimento na volta para casa, que pode ter ocorrido tanto no que se refere à moradia, como à renda. Nesses casos, é preciso que Serviço Social articule com a família a melhor maneira de viabilizar a alta. Em casos em que a família negue auxílio, o paciente costuma sair por meios próprios, solicitar acolhimento institucional ou contar com ajuda de algum amigo, como vemos ocorrer nos relatos apresentados nas fichassociais.

É pertinente mencionar ainda outras demandas que a equipe multidisciplinar atribui ao Serviço Social e que não são privativas ou de referência, como os casos em que o paciente não coopera com a equipe ou mesmo com o tratamento (2\%). Não significa que o assistente social não tenha suas contribuições a fazer nesses casos. Às vezes, uma acolhida ou orientação podem ser valiosas, mas não podem ser demandas exclusivas para esses profissionais, como muitas vezes seapresenta.

Outro dado importante desse gráfico é que $18 \%$ foram casos de pacientes que faziam uso abusivo de álcool e outras drogas. Nesses casos, apenas 10\% tiveram sucesso a partir da interlocução com uma instituição de referência noacompanhamento. 
Gráfico 10- Principais demandas de idosos atendidos pelo Serviço Social

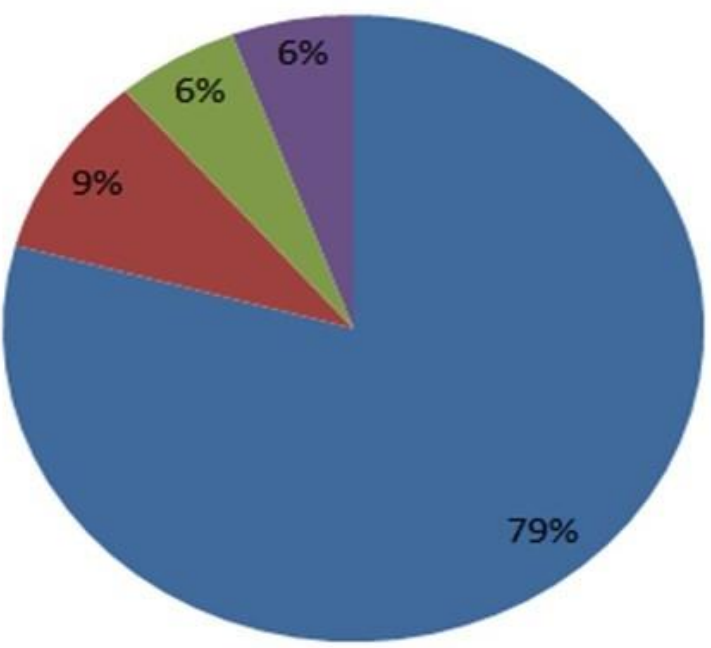

Rede familiar precária e paciente com pouca autonomia

- Rede familiar precária e paciente psiquiátrico

Paciente sem identificação

Fonte: Formulação própria (2019).

Já em relação aos idosos, todos os casos também foram apresentados como "casos sociais". E assim, os dados revelaram que $79 \%$ referiam-se a pacientes com rede familiar que ofereciam pouco suporte e idosos com pouca autonomia para residiremsozinhos. Esses casos culminaram na articulação com a família, quando não havia acolhimento institucional disponível (muito comum no município do Rio de Janeiro) ou mesmo óbito. Além disso, a articulação com as famílias poderia ser mais desafiadora quando envolvia casos de paciente com algum transtornopsiquiátrico.

Jesus (2017) revela que no planejamento da alta hospitalar, o tempo revela-se uma questão bastante relevante, já que, muitas vezes, os profissionais são pressionados para a efetivação da alta hospitalar, o que implica uma rápida intervenção e mobilização de recursos, que nem sempre estão disponíveis no imediato.

No que se refere à participação do profissional de Serviço Social em remoções, como consequência da alta hospitalar, a Resolução n.68/97 do Conselho Regional de Serviço Social - CRESS - estabelece que a sua participação deve ser determinada a partir do diagnósticosocial.

Dos assistentes sociais que participaram da pesquisa de Vasconcelos (2012) e que trabalhavam na atenção terciária, 91\% (noventa e um por cento) declaram participação no processo de alta, os de uma determinada unidade revelaram participação junto à equipe médica e em outras unidades apenas nos 
casos de alta com demandas para o Serviço Social (pacientes sem residência e/ou família, casos que envolvem o Conselho Tutelar ou que envolvem alta para a mãe e não para o bebê, etc).

A participação do Serviço Social nos processos de alta (social ou médica) junto a outros profissionais poderia ser um indicativo de trabalho junto à equipe multiprofissional, porém a pesquisa de Vasconcelos (2012, p. 228) conclui ainda que o trabalho apresentado pelos profissionais entrevistados é muito mais um trabalho articulado de alguns técnicos interessados no programa do que o trabalho de uma equipe articulada que se planeja e trabalha para poder realizar suas ações na direção pretendida.

O Termo de Orientação do CRESS/7ª Região esclarece que a atuação do Serviço Social no processo de alta (e de remoção) dar-se-á a partir de um estudo social que determinará a necessidade de intervenção desse profissional. Se o paciente não estiver em condições de "alta social", cabe ao assistente social notificar à equipe, registrando no prontuário cada passo do processo de intervenção (observado o sigilo profissional), de forma a ratificar o caráter interdisciplinar do atendimento, estabelecendo uma interface do usuário/família com a equipe visando a melhorresolubilidade.

A intervenção do assistente social nessa problemática não é atividade privativa, mas requer ação desse profissional junto a outras equipes para maior chance de sucesso nos casos atendidos.

O que buscamos saber, portanto, é em que medida pode a "alta social" ser adotada pelo Serviço Social como elemento estratégico no enfrentamento dos desafios profissionais para implementação de uma prática reflexiva interdisciplinar e intersetorial.

Desse modo, defendemos que a atuação do Assistente Social, em casos de "alta social", é sim elemento estratégico na atuação interdisciplinar e intersetorial, mas temos clareza, a partir da pesquisa aqui realizada, que em muitos dos casos, a intersetorialidade se resume à articulação com a rede de apoio, ou seja, a intersetorialidade torna-se inviável diante de um quadro de esvaziamento de direitos, principalmente para a população mais empobrecida. 


\section{5 \\ Considerações finais}

Essa pesquisa apresentou dados que podem ser interessantes para atuação do Serviço Social em unidades de saúde e conseguiu responder aos objetivos propostos no início desta investigação.

Assim, identificamos que os principais fatores que determinaram os entraves para altaforam:

- falta de apoio familiar oucomunitário;

- $\quad$ pacientes que dão entrada semidentificação;

- $\quad$ violência contra crianças eadolescentes;

- $\quad$ população em situação de rua sem condições de saúde adequadase;

- falta de acesso aos direitos de pessoas comdeficiência.

O apoio familiar ou comunitário ${ }^{15}$, na maioria das vezes, se torna a única alternativa do paciente para receber alta, frente ao sucateamento de instituições de acolhimento e da ausência de renda fixa dessa população que Ihes garantiriam autonomia para gerir suas próprias vidas.

Essa falta de investimento nas políticas sociais pode acabar trazendo uma culpabilização das famílias. Os profissionais, nesse sentido, precisam estar atentos para não transferirem todas responsabilidades dos cuidados aos pacientes única e exclusivamente para elas.

Outro determinante que apareceu nos casos que demandavam a "alta social" foram pacientes que deram entrada sem identificação e acabaram gerando para o Serviço Social da unidade uma demanda para articulação com as equipes de identificação (DETRAN, IIFP e DDPA). É nesse momento que o Serviço Social é mais requisitado pela equipe multidisciplinar e, apesar de não ser uma demanda privativa, é um trabalho que dá visibilidade à categoria e chave-mestra para ganhar espaço na correlação de forças e, assim, a garantia de permanecermos na luta por outros direitos dos pacientes dentro daquela unidade desaúde.

Em contrapartida, é importante salientar que o Serviço Social não tem como atribuição privativa a identificação de pacientes. Os próprios relatos nas fichas sociais analisadas mostraram que em um dos casos um paciente foi identificado por meio das redes sociais a partir de um compartilhamento de uma

\footnotetext{
${ }^{15}$ Aqui referimo-nos a um vizinho, amigo ou àquele com quem não se tem relacionamento familiar,
} mas que possui um convívio para troca de afetividade. 
foto feito pela profissional da equipe da enfermagem. Certamente, essa atitude pode ser questionada quanto à ética, ao sigilo profissional e ao direito do paciente, mas, ao mesmo tempo, mostra-nos que a identificação de um paciente pode ocorrer por outros meios e outras categorias.

De todo modo, em nossa pesquisa, verificamos que em todos os casos de atuação do assistente social em relação à identificação e reconhecimento do paciente foram realizados por meio da articulação com a rede de apoio e, na maioria dos casos, foi obtido sucesso.

A violência contra crianças e adolescentes é outra demanda que dá visibilidade ao trabalho do assistente social, pois é ele que fará a interlocução com os setores responsáveis visando a proteção da criança e do adolescente e viabilização de seus direitos sociais.

A articulação com as redes nos casos de violação dos direitos da criança e do adolescente, conforme foi apresentada na nossa pesquisa, foi a que mais se nas ações do Serviço Social. Isso se dá pela legislação protetora, instituições atuantes e, principalmente, pelos movimentos participativos que estão envolvidos nessa temática.

Já em relação a demanda para atuação junto à população em situação de rua é um grande desafio imposto à nossa categoria, uma vez que, mais uma vez, as políticas públicas sucateadas inviabilizam nosso trabalho na garantia de moradia. Essa população, em sua maioria, acaba sem muitas perspectivas de atuação do Serviço Social para além de orientações. Isso se torna ainda mais difícil quando estamos tratando de unidades de atenção terciária em que os atendimentos são realizados sem vínculo com o usuário, devido ao pouco tempo de internação e não acompanhamento desses.

Esse estudo mostrou que esse é o principal desafio de atuação do Serviço Social envolvido no processo de alta. Embora tenham firmado todo seu esforço para articulação com a rede, apenas 2 (dois) casos tiveram êxito. Em sua maioria houve saída à revelia ou ainda óbitos.

Nos casos analisados para esse estudo, verificamos que a maior parte da população em situação de rua que davaentrada no hospital já conhecia a realidade das instituições de acolhimento com o mínimo de investimento e não desejavam a vaga, preferindo, até mesmo, o retorno àsruas.

$\mathrm{O}$ acesso aos direitos às pessoas com deficiência, em geral, assim como os casos que envolvem crianças e adolescentes, são casos de maiores sucessos devido à garantia por lei. Mas se resumem em orientações e encaminhamentos. 
Nessa pesquisa, vimos também que o assistente social é requisitado, em sua maioria, em situações que envolvem pessoas não identificadas e violência contra crianças. Das outras demandas que apareceram, não houve, neste estudo, registro de solicitação do acompanhamento do Serviço Social para alta e sim livre atuação desseprofissional.

Por outro lado, observamos também que, em algumas situações, havia registros de atuação do Serviço Social no caso, mas não houve espera da equipe para liberar o paciente. Esse fato ficou nítido em um dos relatos apresentados em que um paciente que apresentava transtornos psiquiátricos, e que recebia acompanhamento do assistente social na busca de localização do familiar, foi liberado de alta pela equipe médica sem prévio aviso à equipe multidisciplinar. O sujeito, então, acatando ordens médicas, teria deixado a unidade por meios próprios. Consta na ficha, que algum tempo depois a família compareceu à unidade procurando o paciente e recebeu a notícia da saída dele e, consequentemente, de seu desaparecimento.

Essa pesquisa mostrou também que em quase $100 \%$ dos casos, uma das primeiras ações do assistente social, após acolhimento do paciente e abertura da ficha social, é a tentativa de acionar a rede de apoio.

De todos os casos em que o Serviço Social acionou a rede, apenas em aproximadamente $17 \%$ houve retorno positivo para contribuição na viabilização ao direito do paciente. Esse número se configura extremamente baixo frente às inúmeras tentativas de articulação intersetorial.

Sobre esse baixo alcance, compreendemos que alguns fatores devem ser levados em consideração para entendermos o motivo de a intersetorialidade ser tão requisitada, mas não apresentar resultadosesperados.

Baseados na Promoção da Saúde, continuamos a sustentar a teoria de que, sim, ela é uma ferramenta que traz ganhos importantes para atuação profissional se fosse corretamente aproveitada.

Porém, o que essa pesquisa mostrou é que a falta de uma proposta política que articule os setores, faz a intersetorialidade se resumir a meras tentativas de contato com a rede.

Outra questão que levantamos e que justifica o baixo aproveitamento da intersetorialidade nos casos de alta com as quais estamos trabalhando nesse estudo, é que a falta de investimentos das políticas públicas tornou-as insatisfatórias. Nos relatos que analisamos para construção dessa pesquisa ficou nítido que, quando um profissional da saúde solicita uma vaga de acolhimento nstitucional para uma pessoa em situação de rua, é extremamente difícil a 
viabilização dessa. A resposta foi quase sempre um pedido de espera por falta de vaga na rede.

Além pouco aporte financeiro dado às políticas sociais, ainda há aqueles setores que possuem mais interesse de investimento em detrimento de outros. Isso pode se dar por interesse político nesse ou naquele setor, maior engajamento na luta por esse ou aquele direito de acordo com os interesses da população, entre outros.

Assim, mesmo que os profissionais da ponta estejam buscando acionar a intersetorialidade fica inviável mediante a um quadro de esvaziamento de direitos, principalmente para os mais pobres.

Então, afirmar que ela é um caminho possível para atuação multiprofissional na intervenção de "alta social" pode se tornar uma fala esvaziada de uma análise crítica.

Mais uma vez, gostaríamos de afirmar que, de maneira nenhuma consideramos descartá-la ou criticamos quando os profissionais a usam como uma das ferramentas principais para atuação em "alta social", mas devemos entender que ela, do jeito que está posta, não garante nem $1 / 4$ da resolutividade dos casos.

Intersetorialidade não é, portanto, a mera articulação entre as redes, embora isso faça parte. Mas é o máximo aproveitamento de um projeto político que vise ao rompimento dos muros das políticas sociais, a partir de investimento efetivo em todas os setores, a fim de que atendam verdadeiramente a demandaapresentada.

Por fim, vislumbramos na alta responsável uma possibilidade para humanização da alta hospitalar. O objetivo é garantir a continuidade do cuidado e evitar a reospitalização.

O processo vislumbra a participação de todos os sujeitos envolvidos (profissionais, gestão, paciente e familiares) e prevê ações intersetoriais, conforme expresso na portaria № 3.390, de 30 de dezembro de 2013.

Desse modo, seria possível eliminarmos a segregação existente no interior dos ambientes hospitalares com relação a alta (social e médica) e traçarmos uma perspectiva de cuidado integral a partir da alta responsável. 


\section{Referências bibliográficas}

AZEVEDO, E. de. et al. Práticas intersetoriais nas políticas públicas de promoção de saúde. Physis Revista de Saúde Coletiva, Rio de Janeiro, 22 [ 4 ], p.1333-1356, 2012.

BELLINI, M. I. B.; FALER, C. S. (Orgs.). Intersetorialidade e políticas sociais: interfaces e diálogos. Dados Eletrônicos. Porto Alegre: EDIPUCRS, 2014. 224p.

BENEVIDES, M. V. Cidadania e Direitos Humanos. Instituto de Estudos Avançados da Universidade de São Paulo, 2004. Disponível em: <www.iea.usp.br/artigos>. Acesso em: 27 nov. 2018.

BRASIL. Código de Ética Profissional o assistente social. Brasília: CFESS, 1993. Brasília, 1988.

Constituição da República Federativa do Brasil,1988. . Lei no 8.080, de 19 de setembro de 1990. Dispõe sobre as condições para promoção, proteção e recuperação da saúde, a organização e o funcionamento dos serviços correspondentes e dá outras providências. Diário Oficial da União, Brasília, Seção 1, 20 set. 1990. p. 18.055. Disponível em:<http://goo.gl/OB8dLp>. Acesso em: 29 nov.2018.

Ministério da Saúde. Portaria GM/MS № 2.446, de 11 de novembro de 2014. Redefine a Política Nacional de Promoção da Saúde. Diário Oficial da União, Brasília, DF, 11 nov. 2014. Disponível em: $<$ http://bvsms.saude.gov.br/bvs/publicacoes/politica_nacional_promocao_ s aude_pnaps.pdf $>$. Acesso em: 18 nov. 2018.

Ministério da Saúde. Gabinete do Ministro. Portaria no 3.390, de dezembro de 2013. Institui a Política Nacional de Atenção Hospitalar (PNHOSP) no âmbito do Sistema ÚnicodeSaúde (SUS), estabelecendose as diretrizes para a organização do componente hospitalar da Rede de Atenção à Saúde (RAS). Diário Oficial da União. Brasília, DF, 30 dez. 2013. Disponível em: <http://bvsms.saude.gov.br/bvs/saudelegis/gm/ 2013/prt3390_30_12_2013.html>. Acesso em: 18 nov. 2018.

BRASÍLIA. Parâmetros para atuação dos assistentes sociais na Política de Saúde. Série: Trabalho e projeto profissional nas Políticas Sociais. Conselho Federal de Serviço Social, 2010.

BRAVO, M. I. S. Serviço Social e reforma Sanitária: lutas sociais e práticas profissionais. 4. ed. São Paulo: Cortez, 2011. 
BUSS, P. M.; FILHO, A. P. Determinantes Sociais de Saúde. Editorial, Caderno Saúde Pública, Rio de Janeiro, 2006.

BUSS, P. M.; FILHO, A. P. A Saúde e seus Determinantes Sociais. Physis: Rev. Saúde Coletiva, Rio de Janeiro, 17(1), p. 77-93, 2007.

CARVALHO, J. M. Cidadania no Brasil: o longo caminho. 19. ed. Rio de Janeiro: Civilização Brasileira, 2015

Cidadania: tipos e percursos. Estudos históricos, 18, 9, p. 357- 424, Rio de Janeiro, 1996.

CARVALHO, G. A saúde pública no Brasil. Estudos avançados, 27 (78), 2013

CFESS. Parâmetros Para Atuação De Assistentes Sociais Na Política De Saúde. Conselho Federal de Serviço Social. 1. ed. Brasília. 2004.

CORREIA, M. V. C. O Conselho Nacional de Saúde e os Rumos da Política de Saúde Brasileira: mecanismo de controle social frente às condicionalidades dos organismos financeiros internacionais. Recife, 2005, 342f. Tese (Doutorado em Serviço Social) - Pós-Graduação em Serviço Social da Universidade Federal de Pernambuco, 2005.

CORREIA, M. V. C.; OMENA, V. C. A mercantilização da saúde e a política de saúde brasileira: a funcionalidade da saúde suplementar. $\mathrm{VI}$ Jornada internacional de políticas públicas: $O$ desenvolvimento da crise capitalista e a atualização das lutas contra a exploração, a dominação e a humilhação. São Luis/ Maranhão. 20 a 23 deagosto de 2013. Disponível em: <http:www.joinpp.ufma.br/jornadas/joinpp2013/JornadaEixo2013/ Anaiseixo3estadolutassociaisepoliticas/pdf/amercantilizacaodasaudeeapo Liticadesaudebrasileira.pdf>. Acesso em: 05 dez. 2018.

COSTA, M. D. H. O Trabalho nos Serviços de Saúde e a Inserção dos(as) Assistentes Sociais. Serviço Social e Saúde Formação e Trabalho Profissional. Ministério da Saúde, 3. ed. Cortez: São Paulo, 2008. p.305351.

Serviço social e intersetorialidade: A contribuição dos assistentes sociais para a construção da intersetorialidade no cotidiano do sistema único de saúde. 2010. 266 f. Tese (Doutorado) - Curso de Serviço Social, Serviço Social, Universidade Federal de Pernambuco, Recife, 2010. Disponível em: <https://repositorio.ufpe.br/bitstream/123456 789/9351/1/arquivo375_1.pdf>. Acesso em: 12 dez. 2018.

COUTINHO, C. N. Notas sobre cidadania e modernidade. Revista de Estudos de Política e Teoria Social, Rio de Janeiro: UFRJ/DP\&A, v. 1, n. 1, p. 145-165, 1997. 
COUTO, B. R. et al. O sistema único de assistência social no Brasil: uma realidade em movimento. São Paulo: Cortez Editora, 2010.

CUNHA, A. A. O serviço social e a alta hospitalar qualificada: um relato de experiência. 2018. 20 f. Monografia (Especialização) - Curso de Programa de Residência Multiprofissional em Saúde, Faculdade de Medicina - Famed, Universidade Federal de Uberlândia, Uberlândia, 2018. Disponível em: <https://repositorio.ufu.br/bitstream/123456789/21693/ 3/ServicoSocialAlta. pdf>. Acesso em: 14 nov. 2018.

DAGNINO, E. Construção democrática, neoliberalismo e participação: os dilemas da confluência perversa. Política e Sociedade, n. 5, 2004. p. 139- 164.

DELAIA, C. R.; FREIRE, I. M. Subsídios para uma política de gestão da informação da Embrapa Solos: à luz do regime de informação. Perspect. ciênc. inf. [online]. 2010, v. 15, n. 3, p. 107-130. Disponível em: <http://www.scielo.br/scielo.php?pid=S1413-99362010000300007\&script=sci_ arttext. Acesso em: 12 nov. 2018.

FAGUNDES, H. S.; NOGUEIRA, V. M. R. O Princípio da integralidade nas políticas nacionais de saúde e assistência social. Sociedade em Debate, Pelotas, EDUCAT, 38, 2008.

FALEIROS, V. P. O Serviço Social no cotidiano: fios e desafios. Serv. Soc. Soc., São Paulo, n. 120, p. 706-722, out./dez. 2014. Disponível em <http://www.scielo.br/pdf/sssoc/n120/07.pdf>. Acesso em: 12 dez. 2018.

FERREIRA, V. S. C.; SILVA, L. M. V. Intersetorialidade em saúde: um estudo de caso. In: HARTZ, Z.M.A.; SILVA, L. M V. (Orgs). Avaliação em saúde: dos modelos teóricos à prática na avaliação de programas e sistemas de saúde [online]. Salvador: EDUFBA; Rio de Janeiro: Editora FIOCRUZ, 2005, p. 103-150. ISBN: 978-85-7541-516-0. Availablefrom: doi: 10.7476/9788575415160. Also available from in e PUB from: <http://books.scielo.org/id/xzdnf/epub/hartz-9788575415160.epub>. Acesso em: 27 set. 2018.

FERnANDES, T. M. D. et al. Ciência \& Saúde Coletiva, 16(2), p. 479-489, 2011.

FORTES, Débora C. B. Políticas de Saúde e de Assistência Social: um comparativo como prevenção contra a janela de uma gestão privatizadora In Textos e Contextos da Política de Assistência Social no Brasil / organização Sindely Alchorne - 1 ed. - Rio de Janeiro. Letra Capital, 2017. 400 p. (Assistência Social e Direitos Humanos, 1).

FÓRUM DA REFORMA SANITÁRIA BRASILEIRA. O SUS pra valer: universal, humanizado e de qualidade. Rio de Janeiro: Abrasco; Cebes; Abres; Rede Unida; Ampasa, 2006. 
FRANÇA, M. C.; CAVALCANTI, P. B. A intersetorialidade e o assistente social na saúde. In: Seminário Internacional Sobre Políticas Públicas, Intersetorialidade e Família, 2013, Porto Alegre. Desafios éticos no ensino, na pesquisa e na formação profissional. Porto Alegre: EDIPUCRS? Editora Universitária da PUC-RS, 2013.

GUERRA, I. O que é o caso social? Estudo sobre a construção do caso social em contexto hospitalar. 2015. Tese de Doutorado em Serviço Social, Lisboa, Faculdade de Ciências Humanas, Universidade Católica Portuguesa.

IAMAMOTO, M. V. Serviço Social: Direitos e Competências Profissionais. Brasília - DF: Abepss,2009.

A questão social no capitalismo. Temporalis, Brasília, n. 3, 2004.

IAMAMOTO, M. V; CARVALHO, R. de. Relações Sociais e Serviço Social no Brasil: esboço de uma interpretação histórico-metodológica. 22. ed. São Paulo: Cortez; [Lima, Peru]: CELATS, 2008.

INOJOSA, R. M. Sinergia em políticas e serviços públicos: desenvolvimento social com intersetorialidade. Cadernos FUNDAP n. 22, 2001, p.102-110.

JESUS, A. C. C. Alta Hospitalar, Serviço Social e Direitos Humanos. 2017. 116 f. Dissertação (Mestrado) - Curso de Serviço Social, Departamento de Sociologia e Políticas Públicas, Instituto Universitário de Lisbos, Lisboa, 2017. Disponível em: <https://repositorio.iscteiul.pt/bitstream/10071/15045/1/Alta\%20Hospitalar\%20Servi\%C3\%A7o\%2 0S ocial\%20e\%20Direitos\%20Humanos.pdf>. Acesso em: 15 nov. 2018.

JUNQUEIRA, L. A. P. Intersetorialidade, transetorialidade e redes sociais na saúde Rio de Janeiro. 34(6), p. 35-45, nov./dez. 2000. Disponível em: <http://bibliotecadigital.fgv.br/ojs/index.php/ rap/article/viewFile/6346/4931. Acesso em: 08 nov. 2018.

KERSTENETZKY, C. L. Foi um pássaro ou um avião? Redistribuição no Brasil no século XXI Novos estud. CEBRAP. São Paulo, v. 36. 02, p. 1534, Julho, 2017.

KONNO, C. C.; BREVILHERI, E. C. L.; BASSI, L. L.; PASTOR, M. A intersetorialidade como estratégia de gestão nas Políticas Sociais: A articulação intersetorial em Londrina. In: RIZZOTI, M. L. A.; CORDEIRO, S. M. A.; PASTOR, M. (Orgs). Gestão de Políticas Sociais: território usado, intersetorialidade e participação. Londrina: Eduel, 2017. Capítulo 4 p. $115-142$. 
LEAL, R. A. S; XAVIER, A. Alta Hospitalar: a importância do trabalho multiprofissional e interdisciplinar em saúde. [Tese] Santa Catarina: Universidade Federal de Santa Catarina, 2014.

LOTTA, G.; FAVARETO, A. Desafios da integração nos arranjos institucionais das políticas públicas no Brasil. Ver. Social. Pollit. [online], 2016, v. 24, n. 57, p. 49-65. ISSN 0104-4478. Disponível em: $<$ http://dx.doi.org/10.1590/1678-987316245704>.

MARSHALL, T. H. Cidadania, classe social e status. Rio de Janeiro: Zahar, 1967

MARTINI, D. et al. A inserção do assistente social na área da saúde: uma reflexão sobre o município de Florianópolis. Congresso Catarinense de Assistentes Sociais. De 22 a 24 de Agosto de 2013. Florianópolis/SC

MARX, K. O capital: Crítica da economia política. 12. ed. Rio de Janeiro: Editora Bertrand Brasil S.a., 1989. Do original em Alemão: Das Kapital: Kritik Derpolitischen Okonomie.

MEDEIROS, Marcelo. A Trajetória do welfarestate no Brasil: papel redistributivo das políticas sociais nos anos 1930 aos anos 1990. In: IPEA. Texto para Discussão, n. 852, Brasília, dez. 2001.

MINAYO, M. C. S. (Org.). Pesquisa social: teoria, método e criatividade. 29. ed. Petrópolis, RJ: Vozes, 2010. (Coleção temassociais).

MIOTO, R. C. T.; SCHUTZ, F. Intersetorialidade na política social: reflexões a partir do exercício profissional dos assistentes sociais. In: O direito à saúde e a proteção social em faixas de fronteiras: um balanço do debate acadêmico no sul da América do Sul. 2011, Pelotas/RS. Disponível em: <http://www.ucpel.tche.br/mps/diprosul/ docs/trabalhos/28.pdf>. Acesso em: 13 out. 2018.

MOTA, A. E. et al. O Mito da Assistência Social: ensaios sobre Estado, Política e Sociedade. São Paulo: Cortez, 2008.

MOTA, A. E. et al. (Orgs.). Serviço Social e saúde: formação e trabalho profissional. São Paulo: Cortez/ABEPSS, 2006.

NETTO, J. P. Cinco Notas a propósito da "questão social". Brasília: Abepss, 2000.

NOGUEIRA, M. A. Introdução - Quarenta anos e algumas transições. Cap. I - Do fracasso à reforma do Estado. In: Um Estado para a sociedade civil: temas éticos e políticos da gestão democrática. São Paulo: Cortez, 2004. Introdução e capítulo I (p. 19-79). 
OLIVEIRA, F. Por quê política? Fórum da Sociedade Civil na Unctad, em São Paulo, 14, 15 e 16 de junho de 2004.

PÁDUA, E. M. M. Metodologia da pesquisa: abordagem teóricoprática. 2. ed. Campinas: Papiros,1997.

PEREIRA, P. A. P. A intersetorialidade das políticas setoriais na perspectiva dialética. In. Monnerat, G.L. Almeida,N.L.T.; Souza, R.G. de (orgs.) A agenda de Políticas Sociais.Campinas, SP: Papel Social, 2014 (p. $23-39)$

PETTRES, A. A.; ROS, M. A.. A determinação social da saúde e a promoção da saúde. Arq. Catarin Med. 2018 jul.set. 47(3), p.183-196.

PRATES, J. C.; PRATES, F. C. Problematizando o uso da técnicade análise documental no Serviço Social e no direito. Sociedade em Debate, Pelotas, 15(2), p.111-125, jul.-dez. 2009.

QUINTINO, T. D.; MATTOS, A. T. R.; BARBOSA, D. C. M.; FORSTER, A. C. As contribuições do assistente social no campo da promoção da saúde: Desafios e Possibilidades .Rev APS. 2012 jul/set; 15(3), p.345355.

RIBEIRO, D. S. 0 direito à saúde em tempos neoliberais: a judicialização da saúde como estratégia para a garantia de direitos? Dissertação (Mestrado) - Programa de Pósgraduação em Serviço Social, Universidade Federal de Juíz de Fora, Minas Gerais, 2014. Disponível em: $<$ http://www.ufjf.br/ppgservicosocial/ files/2014/01/danielle_ribeiro.pdf>. Acesso em: 12 jan. 2018.

SANDRINI, A. C. P. Direitos humanos como garantia de exercício de cidadania: uma reflexão à luz do direito brasileiro. 2006. $113 \mathrm{f}$. Dissertação (Mestrado) - Curso de Ciência Jurídica, Centro de Educação de CiÊnciasJurĺdicas, Polĺticas e Sociais - Cejurps, Universidade do Vale do Itajaí - Univali, Itajaí(sc), 2006. Disponível em: <http://www.dominiopublico.gov.br/download/teste/arqs/cp015416.pdf>. Acesso em: 12 set. 2018.

SANTOS, J. S. "Questão Social": Particularidades no Brasil. Capítulos 3 - Particularidades do capitalismo na formação social brasileira, 4 Particularidades da "questão social" no Brasil e 5 - Aproximações à "questão social" no Brasil contemporâneo. São Paulo: Cortez, 2012. p.94-194.

SANTOS, M. A.; SENNA, M. C. M. Educação em Saúde e Serviço Social: instrumento político estratégico na prática profissional. R. Katál., Florianópolis, v. 20, n. 3, p. 439-447, set./dez, 2017. 
SÁ-SILVA, Jackson Ronie, et al. Pesquisa documental: pistas teóricas e metodológicas. Revista Brasileira de História \& Ciências Sociais, a. 1, n. 1, jul, 2009.

SCLIAR, M. História do Conceito de Saúde. Rev. Saúde Coletiva, Rio de Janeiro, 17(1), p. 29-41, 2007.

SILVA, D. A. J.; TAVARES, M .F. L. Ação intersetorial: potencialidades e dificuldades do trabalho em equipes da Estratégia Saúde da Família na cidade do Rio de Janeiro rio de Janeiro, v. 40, n. 111, p. 193-205, out.dez. 2016.

SILVA, J. P. da. Nota crítica sobre cidadania no Brasil. Idéias.

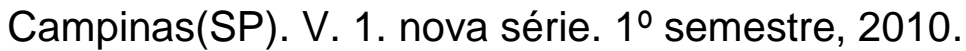

SILVA, K. L. Intersetorialidade, determinantes socioambientais e promoção da saúde. Ciência \& Saúde Coletiva, 19(11), p. 4361-4370, 2014

SIMÕES, C. Curso de direito do serviço social. Biblioteca Básica de Serviço Social. v. 3, 2. ed. São Paulo: Cortez, 2010.

SOUZA FILHO, R.; GURGEL, C. O Estado no capitalismo contemporâneo. In: Gestão democrática e Serviço Social: princípios e propostas para intervenção crítica. São Paulo: Cortez, 2016 - (Coleção biblioteca básica de Serviço Social; v. 7). Capítulo 3 (p.124- 187).

SOUZA, D. O.; SILVA, S .E. V; SILVA, N. O. Determinantes Sociais de Saúde: reflexões a partir das raízes da "questão social". Saúde e sociedade, São Paulo, v. 22, n. 1, p. 44-56, 2013.

TEIXEIRA FLEURY, S. O Dilema da Reforma Sanitária Brasileira. In: BERLINGUER; T. F. e CAMPOS (Orgs.). Reforma Sanitária Itália e Brasil. São Paulo: HUCITEC - CEBES,1988.

VASCONCELOS, A. M. Cotidiano, formação e alternativas na área da Saúde. 8. ed. São Paulo. Cortez, 2012.

Serviço Social e práticas democráticas na saúde. In: MOTA, A. E. et al. (Org.). Serviço Social e saúde: formação e trabalho profissional. São Paulo: Cortez, 2006. p. 242-272.

VIEIRA, M. L. Os rumos da cidadania das pessoas atingidas pela hanseníase: o papel do Morhan no contexto da Constituição de 1988. Dissertação (Mestrado) - Programa de Pósgraduação em Serviço Social, PUC-Rio, Rio de Janeiro, 2009.

Do controle ao participATIVO: engajamento público e informação em hanseníase como caminhos para um novo civismo. Rio de Janeiro, 2015. 


\section{7 \\ Anexos}

7.1.

Anexo 1 - Ficha social HMMC

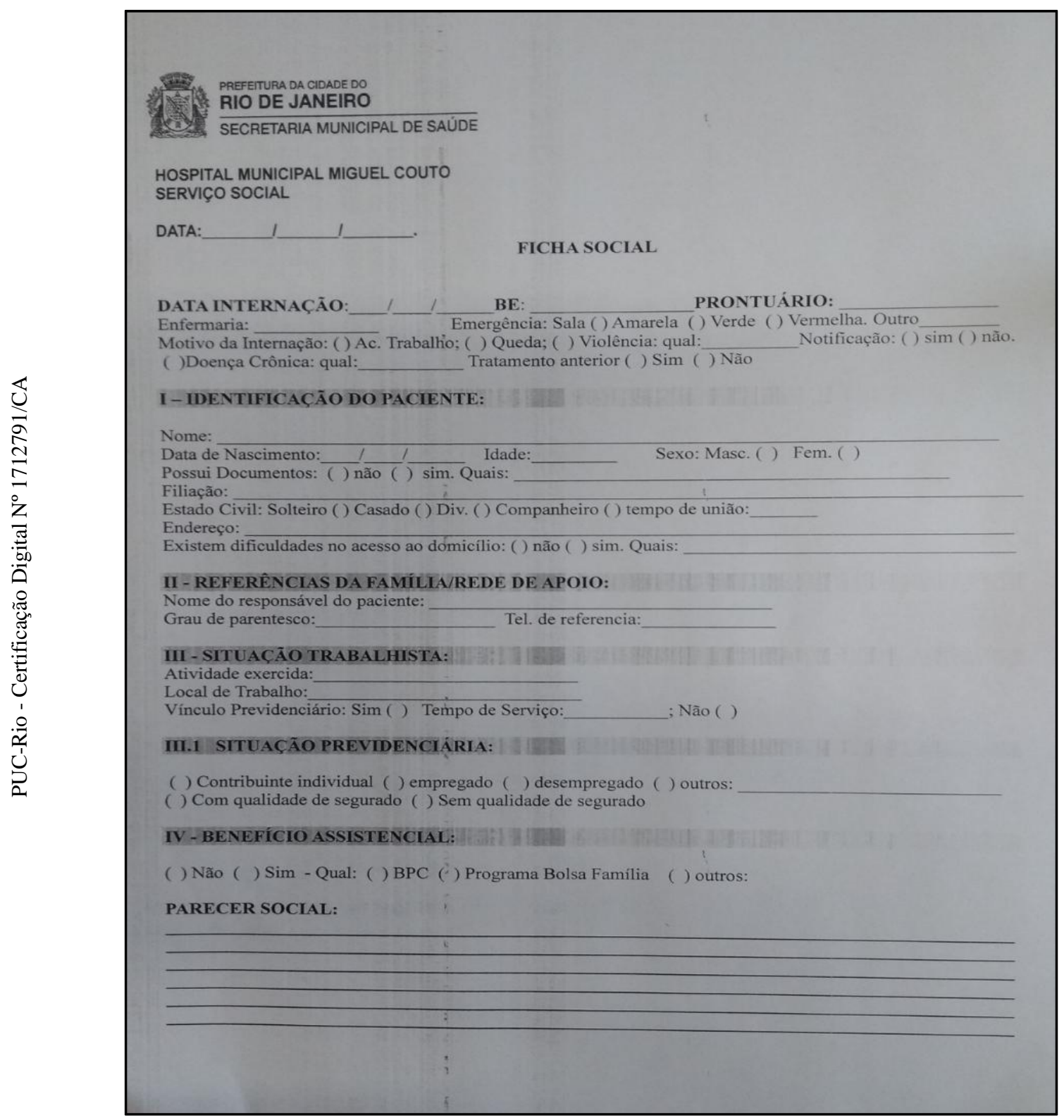




\section{8 Apêndices}

8.1.

Apêndice 1 - Termo de Consentimento Livre e Esclarecido

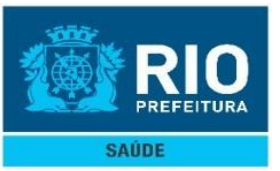

TERMO DE CONSENTIMENTO LIVRE E ESCLARECIDO

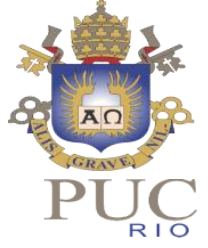

OBRIGATÓRIO PARA PESQUISAS CIENTÍFICAS EM SERES HUMANOS

(RESOLUÇÃO N. 466/2013 - CNS)

\section{DADOS DE IDENTIFICAÇÃO DO PESQUISADOR}

Nome: Débora Cristina Bahia Fortes

Sexo: Masculino ( ) Feminino ( $x$ ) Data Nascimento:.

Endereço: Rua Marques de São Vicente, 225 - Gávea - Cep: 22451-900

Telefone Email:

Título do Protocolo de Pesquisa: Alta Social e Serviço Social: possibilidades a partir da perspectiva intersetorialidade

Orientadora: Sindely Chahim de Avellar Alchorne - Professora do Departamento de Serviço Social da PUC

Endereço do Comitê de Ética em Pesquisa da PUC-Rio: Rua Marquês de São Vicente, 225, Prédio Kennedy - 2º andar - Gávea - RJ. Fone: (21) 3527-1618

Prezado (a) profissional do setor de do hospital
o (a) Sr.
(a) está sendo convidado
(a) para

participar da pesquisa intitulada "Alta Social e Serviço Social: possibilidades a partir da perspectiva da intersetorialidade" de responsabilidade do Departamento de Serviço Social da Pontifícia Universidade Católica do Rio de Janeiro (PUCRio), de autoria da mestranda Débora Cristina Bahia Fortes e sob orientação da professora Dr. ${ }^{\text {a }}$ Sindely Chahim de Avellar Alchorne.

O projeto de pesquisa apresenta como objetivo geral: discutir sobre a "alta social" em uma perspectiva intersetorial e o processo de trabalho dos 
Assistentes Sociais em uma Unidade de Saúde de alta complexidade localizada no bairro do Leblon, no município do Rio de Janeiro - Hospital Municipal Miguel Couto.

Os objetivos específicos da pesquisa são:

- $\quad$ Pesquisar os principais fatores que podem determinar entraves para "alta social";

- Entender quando o assistente social é requisitado para participar do processo dealta;

- $\quad$ Compreender em quais casos os assistentes sociais buscam acionar a rede de apoio e se, nos casos apresentados, houve contribuição para a "alta social" a partir daintersetorialidade;

- Entender como a intersetorialidade se configura como caminho possível para atuação da equipe multiprofissional na intervenção da "altasocial".

Sua contribuição é extremamente relevante para condução e elaboração da referida discussão. Caso concorde em participar da pesquisa, fica implícito por meio deste que estará ciente do caráter voluntário de sua participação no instrumento metodológico a ser adotado. Sua participação não importará em nenhum custo ou quaisquer compensações financeiras. Agendaremos a entrevista previamente, em local de suaescolha.

O conteúdo dos dados levantados, serão armazenados em arquivos no Departamento de Serviço Social da PUC - Rio, serão destruídos após o período de 5 anos. Suas respostas serão tratadas de forma anônima e confidencial, isto é, em nenhum momento será divulgada sua identificação durante ou após o estudo. Os dados coletados serão utilizados apenas nessa pesquisa e os resultados divulgados em eventos e/ou revistascientíficas.

Após os esclarecimentos acima, caso aceite participar da pesquisa, deverá assinar esse documento em duas vias, sendo a primeira de guarda e confidencialidade da pesquisadora responsável e a segunda ficará sob sua responsabilidade para quaisquer fins. Em caso de dúvidas a respeito desta pesquisa, serão garantidas todas as informações a qualquer momento. O (a) Sr. (a) poderá entrar em contato com a pesquisadora Débora Cristina Bahia Fortes pelo celular (21-99552-2696) ou e-mail: bahia.debora@yahoo.com.br e com sua orientadora professora Dr. a Sindely Chahim de Avellar Alchorne por meio do telefone do Departamento de Serviço Social da PUC - Rio (21) 35271001. 


\section{Avaliação do risco da pesquisa:}
(X) RiscoMínimo ( )RiscoMédio
( )RiscoBaixo
( ) RiscoMaior

Riscos e inconveniências: Você poderá se sentir preocupado(a) frente aos dados que solicitaremos. Sinta-se à vontade para esclarecimento de dúvidas e saiba que todos os dados que utilizaremos não inviolabilizarão o local de trabalho e respectivos arquivos e documentação, garantindo o sigilo profissional conforme garante o Código de Ética do Assistente Social, Lei oㅜ 8.662/1993. Você é livre para fornecimento dos dados que achar conveniente.

$$
\text { Eu, }
$$
$R G \quad n^{\circ}$ voluntariamente desta pesquisa. Declaro que li e compreendi todas as informações referentes a este estudo, os procedimentos a serem realizados e as garantias deconfidencialidade.

(Assinatura do entrevistado/a)

(Data)

(Nome da pesquisadora responsável)

(Data) 